Development of a novel chlamydia growth-monitoring method and its application for screening anti- and pro-chlamydial compounds

Ph.D. Thesis

\author{
Anita Varga-Bogdanov M.Sc. \\ Institute of Clinical Microbiology \\ Department of Medical Microbiology and Immunobiology \\ Faculty of Medicine \\ University of Szeged

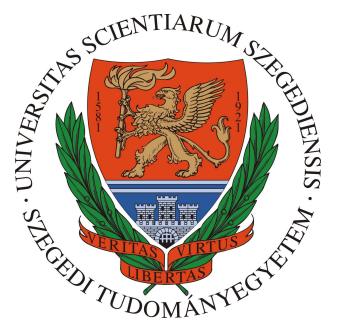 \\ Supervisors: \\ Professor Judit Deák M.D., Ph.D. \\ Institute of Clinical Microbiology \\ University of Szeged \\ Dezső Virók M.D., Ph.D. \\ Department of Medical Microbiology and Immunobiology \\ Faculty of Medicine \\ University of Szeged
}

Szeged

2017 


\section{Publications related to the thesis}

I. Anita Bogdanov, Valeria Endrész, Szabolcs Urbán, Ildikó Lantos, Judit Deák, Katalin Burián, Kamil Önder, Ferhan Ayaydin, Péter Balázs, Dezső P. Virok Application of DNA Chip Scanning Technology for Automatic Detection of Chlamydia trachomatis and Chlamydia pneumoniae Inclusions Antimicrob. Agents Chemother. 58, 405-413 (2014).

II. Anita Bogdanov, László Janovák, Ildikó Lantos, Valéria Endrész, Dániel Sebők, Tamás Szabó, Imre Dékány, Judit Deák, Zsolt Rázga, Katalin Burián, Dezső P. Virok Non-Activated Titanium-Dioxide Nanoparticles Promote the Growth of Chlamydia trachomatis Journal of Applied Microbiology Online (2017)

IF: 2.099

\section{Publication not related to the thesis}

I. Jaishankar D, Yakoub AM, Bogdanov A, Valyi-Nagy T, Shukla D.

Characterization of a proteolytically stable D-peptide that suppresses herpes simplex virus 1 infection: implications for the development of entry-based antiviral therapy. Journal of Virology. 89, 1932-1938 (2015)

IF: 4.439 


\section{Table of Contents}

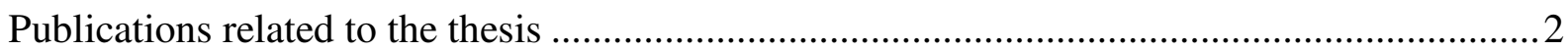

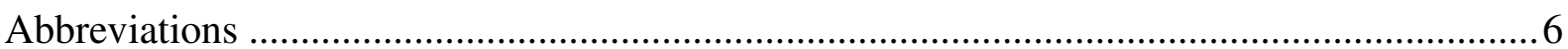

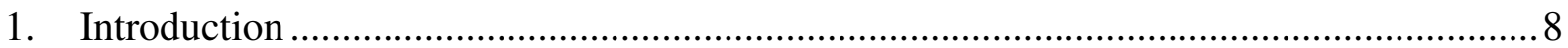

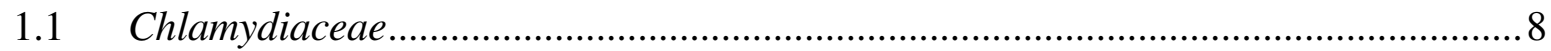

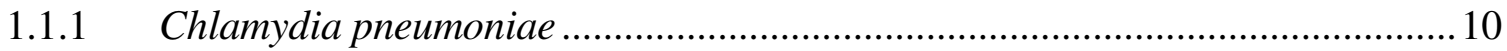

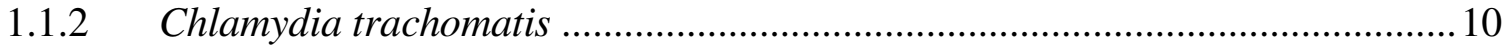

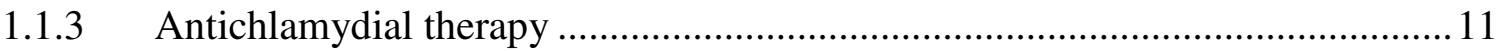

1.1.4 The evolution of the chlamydial diagnosis ................................................. 11

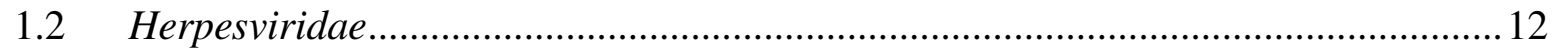

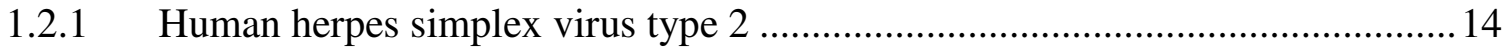

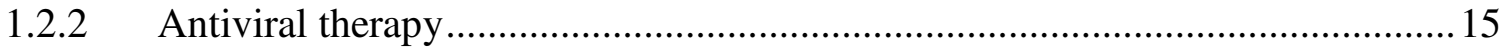

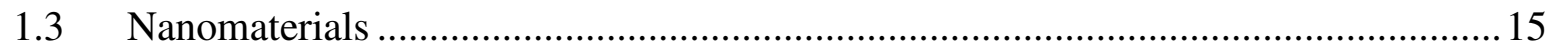

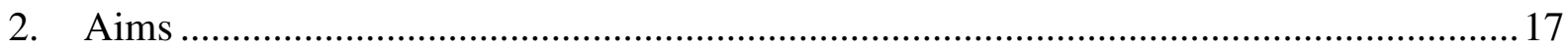

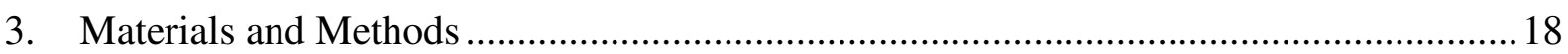

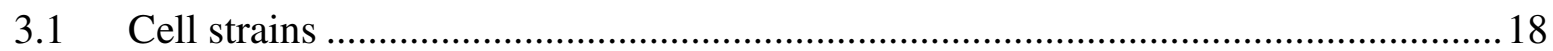

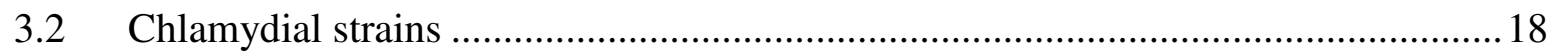

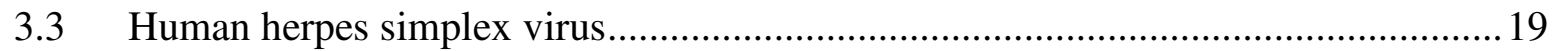

3.4 3-(4,5-dimethyl-2-thiazolyl)-2,5-diphenyl-2H-tetrazolium bromide (MTT) assay... 19

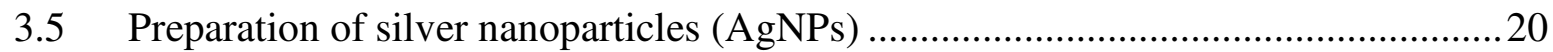

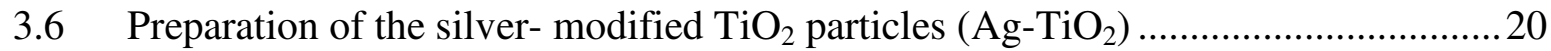

3.7 Transmission electron microscopy measurements of $\mathrm{TiO}_{2^{-}}, \mathrm{Ag}$ - and $\mathrm{TiO}_{2}-\mathrm{Ag}$ NPs 20

3.8 Surface charge measurements of the $\mathrm{TiO}_{2^{-}}, \mathrm{Ag}$ - and $\mathrm{TiO}_{2}-\mathrm{Ag}$ NPs ........................20

3.9 Investigation of the impact of NPs on C. trachomatis growth in HeLa cells ...........21 
3.10 Investigation of the impact of NPs on HSV-2 growth in Vero cells

3.11 Monitoring the growth of C. trachomatis and HSV-2 by direct quantitative PCR (qPCR)

3.12 Culture of Chlamydiae on chamber slide

3.13 Inhibition of chlamydial growth with antibiotics and IFN- $\gamma$

$3.14 \mathrm{TiO}_{2} \mathrm{NP}$ treatment of HeLa cells and monitoring of $C$. trachomatis growth on a chamber slide system

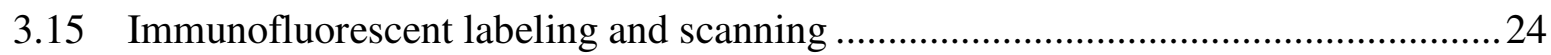

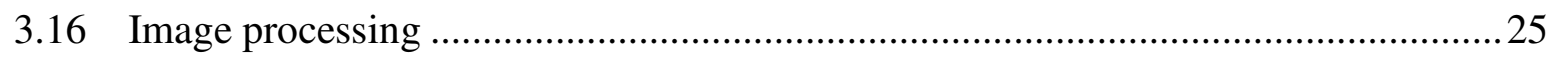

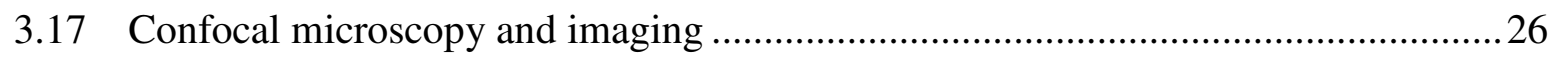

3.18 Transmission electron microscopy measurements of early interaction of $\mathrm{TiO}_{2} \mathrm{NPs}$

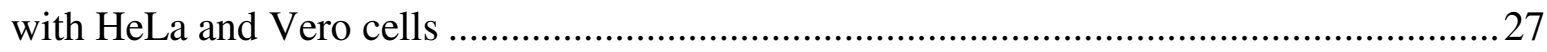

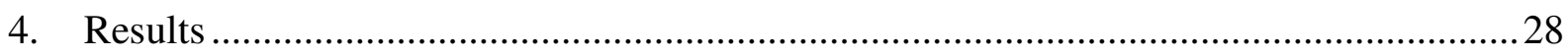

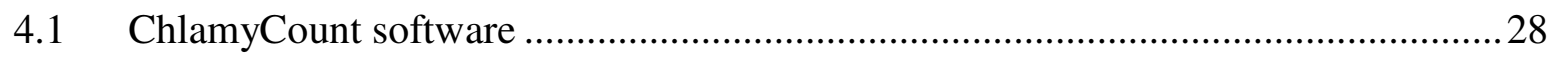

4.2 Measuring the dynamic range of detection of C. trachomatis serovar D, C.

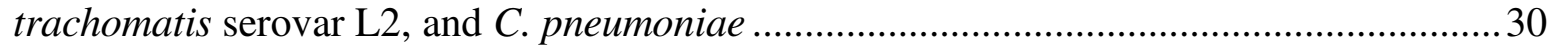

4.3 Assessment of the minimal inhibitory concentration (MIC) of moxifloxacin, tetracycline, and the novel antichlamydial compound PCC00213 for C. trachomatis serovar

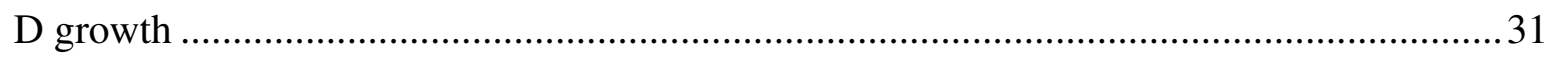

4.4 Assessment of the effect of IFN- $\gamma$ on C. trachomatis serovar D and DEAE-dextran and cycloheximide on $C$. trachomatis serovar D and $C$. pneumoniae growth .................... 34

4.5 Morphological and surface charge properties of the $\mathrm{TiO}_{2^{-}}, \mathrm{Ag}$ - and $\mathrm{TiO}_{2}-\mathrm{Ag}$ NPs... 36

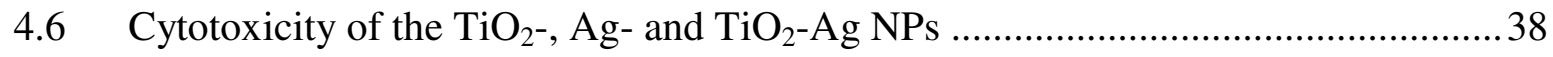

4.7 Assessment of the impact of the $\mathrm{TiO}_{2^{-}}, \mathrm{Ag}$ - and $\mathrm{TiO}_{2}-\mathrm{Ag}$ NPs on C. trachomatis and HSV-2 growth by direct qPCR

4.8 Estimation of the time dependence of the $\mathrm{TiO}_{2}$ growth enhancing effect on $C$. trachomatis 40

4.9 Estimation of the direct impact of the $\mathrm{TiO}_{2}-$, Ag- and $\mathrm{TiO}_{2}-\mathrm{Ag}$ NPs on the $\mathrm{qPCR} . . .41$ 
4.10 Quantitative immunofluorescent measurement of the impact of $\mathrm{TiO}_{2}$ NPs on $C$.

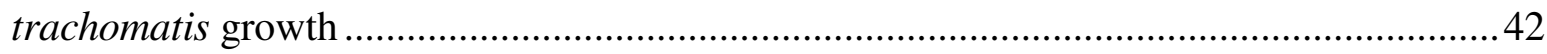

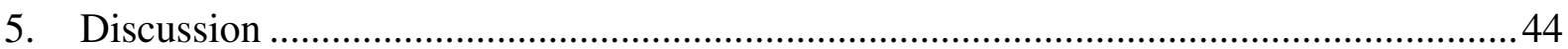

5.1 Aim 1: To develop an automatic system for counting the chlamydial inclusions: ChlamyCount Software.

5.2 Aim 2: To investigate the impact of novel compounds and nanomaterials on the

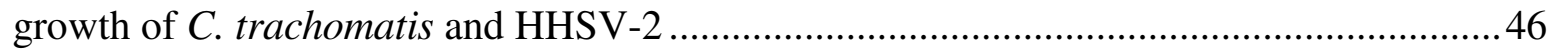

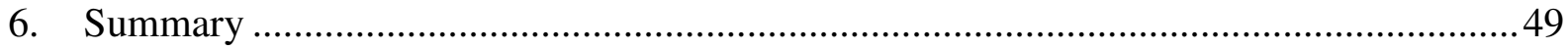

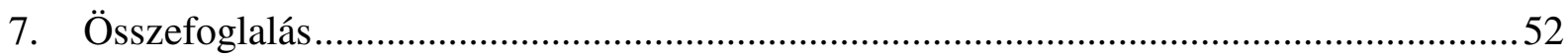

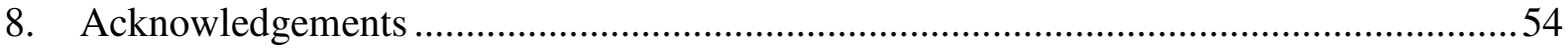

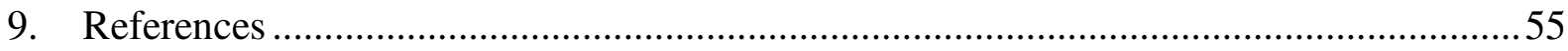




\section{Abbreviations}

Ag

Ag- $\mathrm{TiO}_{2}$

3-OS HS

AB

AIDS

C. trachomatis

C. pneumoniae

COPD

CVD

DNA

DMEM

EB

FBS

HBSS

HHV

HHSV

HHSV-1

HHSV-2

HHV-3/VZV

HHV-4/EBV

HHV-5/HCMV

HHV-8/KSHV

IFN- $\gamma$

IFU

LGV

LPS

MEM

MIC

MOI

MOMP silver

silver- modified $\mathrm{TiO}_{2}$

3-O-sulfated heparin sulfate

aberrant body

acquired immune deficiency syndrome

Chlamydia trachomatis

Chlamydia pneumoniae

chronic obstructive pulmonary disease

coronary vascular disease

deoxyribonucleic acid

Dulbecco's modified minimal Eagle's medium

elementary body

fetal bovine serum

Hank's balanced salt solution

human herpes virus

human herpes simplex virus

human herpes simplex virus-1

human herpes simplex virus -2

varicella-zoster virus

Epstein-Barr virus

human cytomegalovirus

Kaposi's Sarcoma-associated herpesvirus

interferon gamma

inclusion forming unit

lymphogranuloma venereum

lipopolysaccharide

minimal essential medium

minimal inhibitory concentration

multiplicity of infection

major outer membrane protein 
MTT assay

MQ water

NP

PBS

PCR

p.i.

PID

PLT agents

QPCR

RB

ROS

RT

SDS

SPG buffer

STIs

TEM

$\mathrm{TiO}_{2}$

UV light
3-(4,5-dimethyl-2-thiazolyl)-2,5-diphenyl-2H-tetrazolium bromide assay

Milli-Q water

nanoparticle

phosphate-buffered saline

polymerase chain reaction

post-infection

pelvic inflammatory disease

the agents of psittacosis, lymphogranuloma venereum and trachoma quantitative polymerase chain reaction

reticulate body

reactive oxygen species

room temperature

sodium dodecyl sulfate

sucrose-phosphate-glutamic acid buffer

Sexually transmitted infections

transmission electron microscopy

titanium-dioxide

ultraviolet light 


\section{Introduction}

Sexually transmitted infections (STIs) are among the most common causes of illnesses in the world. Chlamydiae and human herpes simplex viruses (HHSV) cause infections that are common throughout the world.

The present study was designated to improve our current understanding of the antimicrobial treatment of Chlamydiae and antiviral therapy of HHSV and to demonstrate a new chlamydial quantification method.

\subsection{Chlamydiaceae}

The Chlamydiaceae is a family of bacteria that belongs to the phylum Chlamydiae, order Chlamydiales. The Chlamydiaceae family contains Gram negative, obligate intracellular bacteria.

On the basis of the taxogenomic researches, instead of the two genera of the Chlamydiaceae family, in 2013 the International Subcommittee for Chlamydial Taxonomy decided to become one genus again, namely the Chlamydia genus. The genus was expanded with newly discovered species (Figure 1.) [1]. Three members of the family Chlamydiaceae, phylum Chlamydiae; Chlamydia trachomatis, Chlamydia (former Chlamydophila) pneumoniae and Chlamydia psittaci are among the best known bacterial pathogens [2]. Chlamydia trachomatis (includes three human serotypes: serovars A-C, serovars D-K, serovars L1-L3) is responsible for trachoma cases worldwide and also represents the most frequently sexually transmitted bacterial disease. Chlamydia pneumoniae is the cause of up to $10 \%$ of community-acquired pneumonia cases and is putatively associated with a number of chronic diseases such as arteriosclerosis and Alzheimer's disease. Chlamydia psittaci is the pathogenic agent of ornithosis or psittacosis, a primarily avian respiratory disease which can manifest as a zoonotic disease in humans $[2,3]$. 


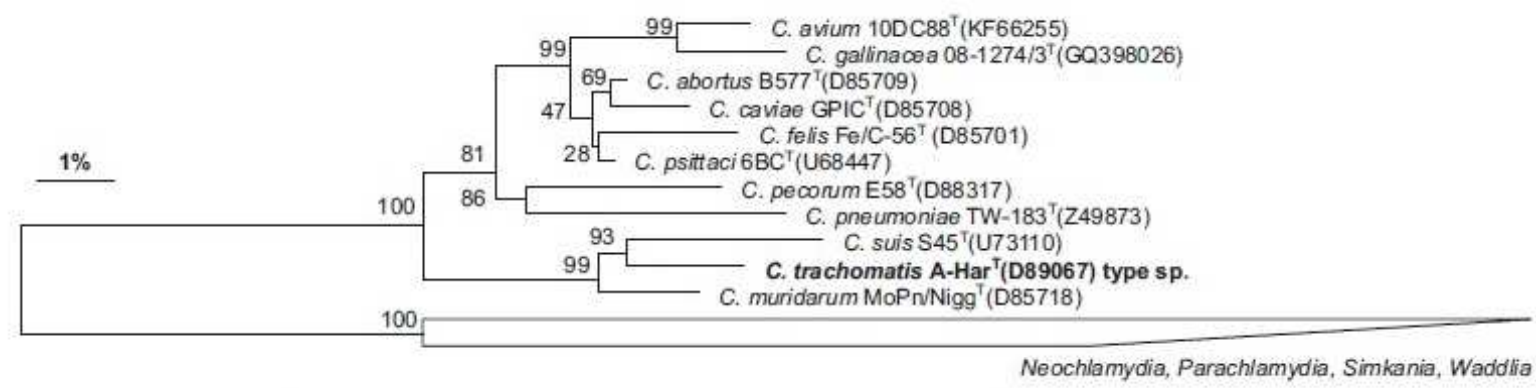

Figure 1. Phylogenetic reconstruction based on almost complete 16S rRNA genes from type strains of established Chlamydiaceae spp., including the recently proposed new species $C$. avium and $C$. gallinacea. Construction of the tree was based on the RAxML algorithm without any filter removing hypervariable positions [1].

Chlamydiae have a unique biphasic developmental cycle (Figure 2.). During this cycle the bacterium is found in two forms the extracellular elementary body (EB) and the reticulate body $(\mathrm{RB})$. The extracellular elementary body form of the bacteria can attach and invade host-epithelial cells, the EBs are metabolically inert and infectious. The intracellular RBs are metabolically active, replicative but non-infectious form of the pathogen. The development cycle of the chlamydia is separated in five major steps: the EB attaches and enters the host cell to generate the inclusion; inside the inclusion, the EB differentiates into a $\mathrm{RB}$; RBs divide by binary fission; increasing numbers of RBs differentiate back to EBs; newly formed EBs are released by cell lysis or extrusion from the host cell to infect the neighbor cells. The duration of the developmental cycle, $\sim 48-72 \mathrm{hrs}$ is depending of the chlamydial species [4].

Chlamydia can enter in an atypical, intracellular and metabolically less active state named persistence, during which they exist in an enlarged aberrant body (AB). Several different stimuli can induce persistence of Chlamydiae in vitro: exposure to interferon- $\gamma$ (IFN$\gamma)$ and antibiotics; heat shock; depletion of essential nutrients. Persistence is reversible, after the inducer is removed Chlamydiae continue their productive replication [5].

Reactivation of persistent Chlamydiae in vivo showing that chlamydial recurrences were more probable due to the reactivations of persistent infections than to re-infections [6,7]. 


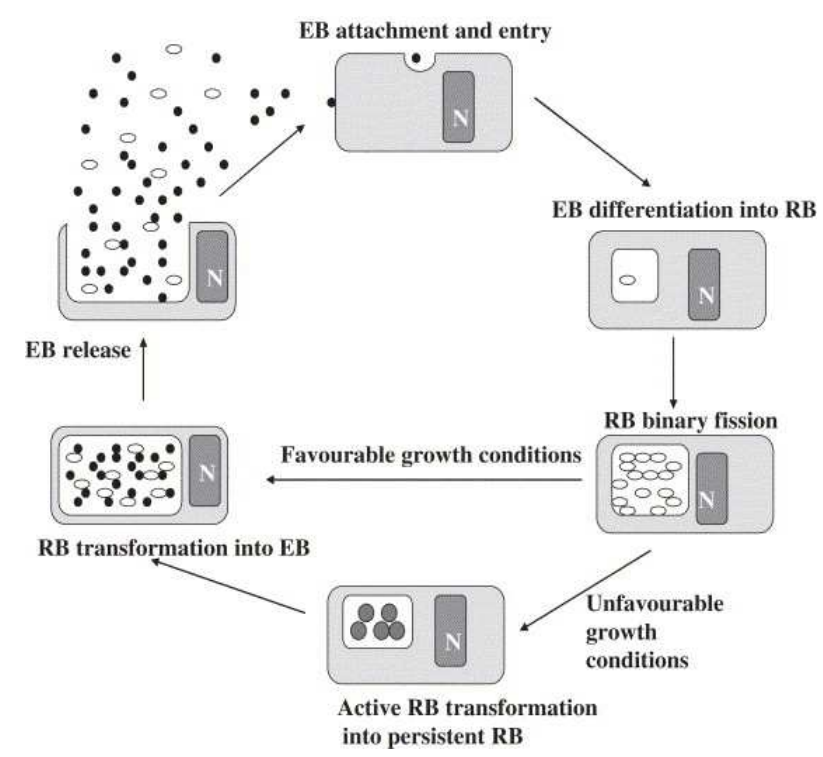

Figure 2. General overview of the chlamydial developmental cycle N: nucleus RB: reticulate body EB: elementary body [5]

\subsubsection{Chlamydia pneumoniae}

Chlamydia pneumoniae (C. pneumoniae) is a common respiratory pathogen and transmitted from human to human without zoonotic host, and responsible for $10 \%$ of pneumonia and 5\% of bronchitis and sinusitis [8]. It is recently reported that $C$. pneumoniae is associated with asthma, atherosclerosis, multiple sclerosis and lung cancer and C. pneumoniae may trigger acute exacerbation of adult asthma [9-12]. Most respiratory infections caused by C. pneumoniae are mild or asymptomatic. Some studies have suggested a possible association of $C$. pneumoniae infection and acute exacerbations of asthma and chronic obstructive pulmonary disease (COPD) as well [13-15].

Studies show that infectious microbial agents, such as C. pneumoniae, are important cause in development of the atherosclerosis. Atherosclerosis is the leading cause of coronary vascular disease (CVD) and acute myocardial infarction [10,16-20].

\subsubsection{Chlamydia trachomatis}

Chlamydia trachomatis (C. trachomatis) includes three human biovars and 19 serovars according to the antigenetic characteristic of the major outer membrane proteins. Different serovariants of $C$. trachomatis cause wide range of diseases: blinding trachoma (serovars AC); urethritis, pelvic inflammatory disease, ectopic pregnancy, neonatal pneumonia, and 
neonatal conjunctivitis (serovars D-K); lymphogranuloma venereum (serovars L1-L3) [20,21]. C. trachomatis infections are asymptomatic in up to $90 \%$ of women and more than $50 \%$ of men [22,23]. In symptomatic patients, the incubation period is between 1 and 3 weeks. Non-specific symptoms such as abnormal vaginal discharge, intermenstrual bleeding, dysuria or pyuria can develop in women. In men, dysuria is the most common symptom [24]. An untreated $C$. trachomatis infection in women can cause serious consequences urethritis, cervicitis, salpingitis, pelvic inflammatory disease (PID), chronic pelvic pain, extrauterine pregnancy and perihepatitis [25]. In men it can cause urethritis, epididymitis and orchitis [23]. Chlamydial infection of the rectal mucosa can cause proctitis with rectal pain and discharge [24,26]. Subfertility and infertility in men and women as well [27-29]. C. trachomatis is primarily associated with sexual risk behaviors: unprotected sexual contact, multiple sex partners, young age, and young age at the first intercourse, ethnics groups [30-32]. $C$. trachomatis prevalence may differ among ethnic groups because of differences in sexual risk behavior $[33,34]$.

\subsubsection{Antichlamydial therapy}

Chlamydiae are sensitive to tetracyclines, macrolides and some fluoroquinolones. Azithromycin and doxycycline are first-line drugs [7,35,36]. Azithromycin is given as a single oral dose for non-LGV C. trachomatis infection and doxycycline preferred for LGV. Erythromycin and fluoroquinolones are alternatives. Doxycycline is an alternative for $C$. trachomatis infection, for treating LGV. For trachoma, a single dose of azithromycin is the treatment of choice [35].

Doxycycline is the contraindication in the second and third trimester of the pregnancy. Ofloxacin and levofloxacin are the suggested treatment with lower risk to the fetus during pregnancy [37,38]. Azithromycin is safe, effective and suggested as well [39]. After 3-4 weeks completion of the therapy another test is recommended, because severe sequelae can occur if the infection persists $[7,40]$.

\subsubsection{The evolution of the chlamydial diagnosis}

The detection and study of the Chlamydiae passed through an enormous evolution in the last hundred years. This evolution starting from the application of simple light microscopy, the cell culture techniques, antibiotic susceptibility, antigen and antibody 
detection, serotyping, to the real-time nucleid acid amplification and restriction fragment lengths polymorphism analysis [41].

In the first period, until the early 1970s the following staining methods were used for chlamydia detection: Gram, Giemsa, staining with iodine and Castaneda as well, but none of them was good for the all chlamydial species [41]. Until the early 1930s, animal inoculation was the only mean for the cultivation of Chlamydiae, nowadays tissue and cell cultures (McCoy, HeLa, Hep2) are used. In 1931 a new method was described by Woodruff and Goodpasture, it was the method with embryonated eggs. Burnet and Rountree cultivated successfully the causative agent of psittacosis (chorio-allantoic membrane) and Miyagawa et al. cultivated for the first time the causative agent of lymphogranuloma inguinale using the same method of egg inoculation.

From 1960 the evolution of the methods was faster. Nichols and McComb suggested the application of a fluorescent-labelled antibody method and Ross and Borman developed a new direct and indirect test for the PLT agents. Studies on species and serotype markers determination and production of monoclonal antibodies established new and specific diagnostic methods for antigen and antibody detection: micro-immunofluorescense assay, enzyme-linked immunosorbent assay. The original chlamydia count is indirectly measured by labeling and manual microscopy counting of inclusions on cover slides [42]. The manual method need around 1 to 3 hours per cover slide to count the inclusions. The laboratory experiments are important to determine the minimal inhibition concentration (MIC) value of antimicrobial compounds.

In 1989 was performed the first successful nucleic acid amplification of $C$. trachomatis by the polymerase chain reaction (PCR) and the first $C$. trachomatis DNA hybridization probe assay was introduced into the diagnostic [41].

The original chlamydia count is indirectly measured by labeling and manual microscopy counting of inclusions [42]. The manual method need around 1 to 3 hours per cover slide to count the inclusions. The laboratory experiments are important to determine the minimal inhibition concentration (MIC) value of antimicrobial compounds.

\subsection{Herpesviridae}

The Herpesviridae family contains large, enveloped, double-stranded DNA viruses. Eight human herpes viruses (HHVs) and a very large number of animal herpes viruses have 
been identified. The HHVs include: human herpes simplex virus type 1 (HHSV-1) and type 2 (HHSV-2), which cause facial and genital lesions; varicella-zoster virus (VZV/HHV-3), which causes chickenpox and shingles; Epstein-Barr virus (EBV/HHV-4), an infectious cause of mononucleosis and Burkitt lymphoma (BL); human cytomegalovirus (HCMV/HHV-5) a leading cause of congenital hepatosplenomegaly, anemia, thrombocytopenia, low birth weight, microcephaly, and chorioretinitis; HHV types 6 and 7 (HHV-6 and HHV-7), which cause roseola; and Kaposi Sarcoma (KS)-associated herpes virus (KSHV), also known as HHV-8.

The replication of HHSV is representative of all human herpes viruses (Figure 3.). HHSV generally causes lytic infection in epithelial cells and latter establishes latency in neuronal cells, most in the trigeminal ganglion. Following infection of a cell, a cascade of herpes virus proteins, called immediate-early, early and late are produced. The glycoproteins in the HHSV envelope interface with cellular receptors, including initial binding to heparan sulfate and subsequent interaction with higher affinity receptors, leading to fusion with the cell membrane [43]. Seroepidemiological studies shows that $90 \%$ of the population became infected with herpes viruses (HHV-1 and HHV-2) before the age of 30 and re-infection during their lifetime.

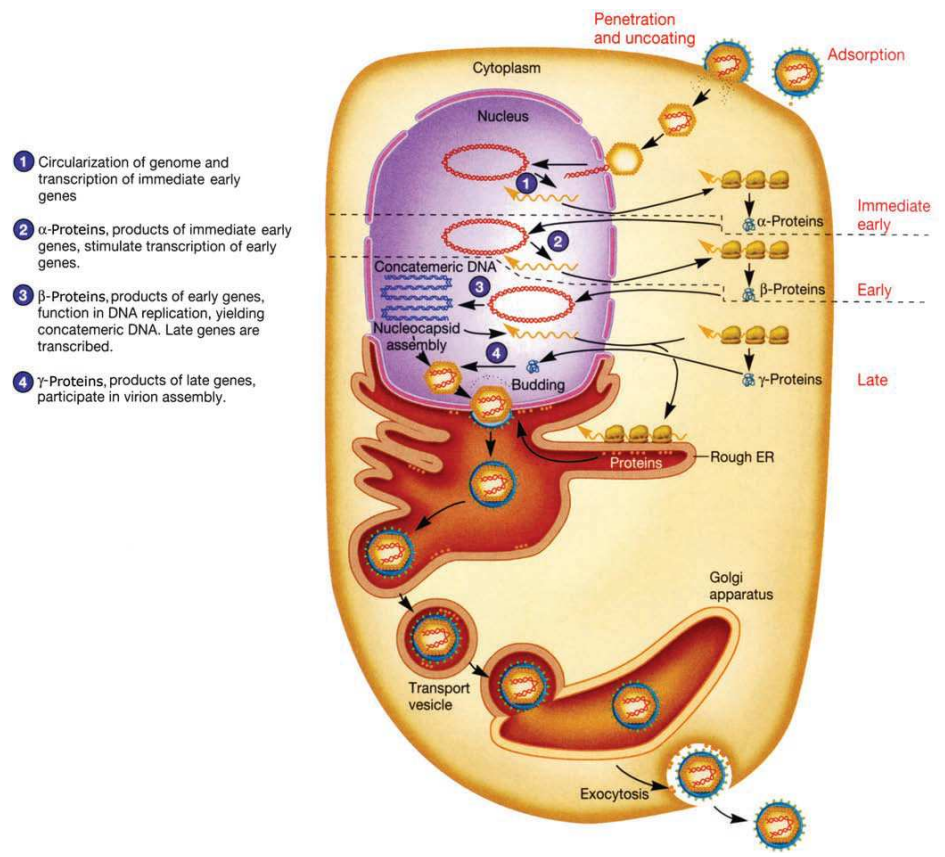

Figure 3.: Replication cycle of the HHSV-1 [44] 


\subsubsection{Human herpes simplex virus type 2}

Human herpes simplex virus type 2 (HHSV-2) mostly cause genital herpes, which is a significant sexually transmitted disease. The symptoms and sign of the acute infection are similar for the genital infection of HHSV-1 and HHSV-2. HHSV-2 can also cause encephalitis in neonates, as a primary infection acquired from the mother $[45,46]$.

There are two types of the genital herpes infection, primary genital herpes and recurrent genital herpes infection [47].

The incubation period of the primary genital HHSV disease from the sexual contact to the first lesions is 5 days. The genital lesions are multiple, extensive and bilateral. The vesiculopustular lesions break to form painful coalesced ulcers that consequently dry, in 3-5 days. Inguinal lymph nodes are usually present, bilateral inflamed tender and may persist for weeks or months. Systemic symptoms such as fever, malaise, and myalgia, and approximately $1 \%$ increase aseptic meningitis with neck stiffness and cruel headache are showed in one-third of the patients. First episodes of disease are persistent an average of 12 days [48-50].

Recurrent genital herpes is a disease of shorter duration, usually restricted in the genital region and without systemic symptoms, in contrast to primary genital infection. Grouped vesicular lesions in the external genital region are usually presented by the recurrent genital herpes. Pain and itching are mild, lasting 4-5 days and lesions usually preceding 2-5 days. Minimum $80 \%$ of patients with primary, symptomatic, genital HHSV-2 infection develop recurrent episodes of genital herpes in 12 months, in patients whose lesions recur, the median number of recurrences is 4 or 5 per year. Recurrences result from reactivation of virus from dorsal root ganglia [44,51].

Neonatal herpes usually results from transmission of virus during delivery through infected genital secretions from the mother to the infant. The incubation period can last as long as 2 to 4 weeks. Some infants show disseminated disease with widespread internal organ participation and necrosis of the liver and adrenal glands, other newborns have involvement of the central nervous system but other`s disease limited to the skin, eyes, and/or mouth only $[52,53]$. 


\subsubsection{Antiviral therapy}

Several antiviral drugs have developed that can inhibit the HHSV infection. The acyclovir is the most commonly used antiviral drug. Acyclovir is a nucleoside analog, which is converted by a viral enzyme (thymidine kinase) to a monophosphate form and then by cellular enzymes to the triphosphate form, which is an affective inhibitor of the viral DNA polymerase through chain termination [54]. From immunocompromised patient (especially with AIDS) with persistent lesions, acyclovir-resistant HHSV has been recovered. Foscarnet is active against acyclovir-resistant HHSV [55].

Valacyclovir and famcyclovir have approved for the treatment of recurrent genital HHSV as well [56]. Valacyclovir is a prodrug of acyclovir with better bioavailability (about $55 \%$ ) than acyclovir (10-20\%). Valacyclovir is not more effective than acyclovir, but can be given in lower doses and less frequently (500 mg twice daily) [57]. Famcyclovir is prodrug of pencyclovir. The bioavailability of famcyclovir is also high (77\%) [58].

\subsection{Nanomaterials}

The antimicrobial effects of metals like silver, zinc or coper have been known and these are used in medicine for infection control. In this study the titanium dioxide, silver and silver/titanium dioxide composites was used, against $C$. trachomatis and HHSV-2. Nanoparticles (NPs) were used in this study.

Titanium dioxide $\left(\mathrm{TiO}_{2}\right)$ is the naturally occurring oxide of titanium. $\mathrm{TiO}_{2}$ exist in three most common forms: rutile, anatase and brookite. Titanium dioxide, in the anatase form, is a photocatalyst under ultraviolet (UV) light. The positive holes oxidizes water to create hydroxyl radicals, by the strong oxidative potential [59]. $\mathrm{TiO}_{2} \mathrm{NPs}$ has a strong bactericidal effect. The $\mathrm{TiO}_{2}$ reacts by photocatalysis with water to release the hydroxyl radical with subsequent formation of superoxide [60]. The ROS can then synergistically act by attacking polyunsaturated phospholipids in bacteria and catalyzed site-specific DNA damage via generation of $\mathrm{H}_{2} \mathrm{O}_{2}$ [61].

$\mathrm{TiO}_{2}$ nanoparticles have been used as whitening agent, food additive (E171) and a drug delivery vehicle $[62,63]$. $\mathrm{TiO}_{2}$ nanotubes are potential to be used as a drug vehicle in the area of nanomedicine, like for bone regeneration or cancer therapy [64]. Biocompatible titania nanotubes and films with large catalytic surface area are perfect as vehicles for carrying drug 
$[65,66]$. A wide range of disorders can be treated by using novel nanoparticle drug delivery systems: cancer treatment, thrombolytic treatment, arthritis and diabetes mellitus [67] [68,69].

Silver ions and silver-based compounds are highly toxic to microorganisms and showing strong biocidal action on many species of bacteria, Gram-negative ad Gram-positive as well. Silver ions have an effect on the bacterial membrane respiratory electron transport chains and DNA replication components. The DNA loses its replication ability and cellular proteins become inactivated on $\mathrm{Ag}^{+}$treatment [70]. Silver NPs were used in our study to inhibit the infections.

Silver-modified $\mathrm{TiO}_{2}$ particles $\left(\mathrm{Ag}-\mathrm{TiO}_{2}\right)$ was prepared and used in our experiment to check the antimicrobial efficacy without photocatalysis [71]. 


\section{Aims}

The present study was designed to address the following aims:

Aim 1: To develop an automatic system for counting the chlamydial inclusions.

The standard method for counting Chlamydiae is immunofluorescent staining and manual counting of chlamydial inclusions. High- or medium-throughput estimation of the reduction in chlamydial inclusions should be the basis of testing antichlamydial compounds and other drugs that positively or negatively influence chlamydial growth, yet low-throughput manual counting is the common approach. To overcome the time-consuming and subjective manual counting, we would like to develop an automatic inclusion-counting system based on a commercially available DNA chip scanner.

\section{Aim 2: To investigate the impact of novel compounds and nanomaterials on the growth of C. trachomatis and HHSV-2}

Chlamydia trachomatis and herpes simplex virus are the most prevalent bacterial and viral sexually transmitted infections. Due to the chronic nature of their infections, they are able to interact with titanium-dioxide nanoparticles applied as a food additive or a drug delivery vehicle. We want to test their interactions with Chlamydia trachomatis and human herpes simplex virus-2 to develop their efficacy in non-activated form. Our study focused on titanium-dioxide nanoparticles, silver nanoparticles and silver decorated titanium-dioxide nanoparticles efficacy on $C$. trachomatis and human herpes simplex virus-2 infections. 


\section{Materials and Methods}

\subsection{Cell strains}

HeLa 229 (ATCC), McCoy (ATCC) and Vero cells (ATCC) were used in this study. The cells were cultivated on 96-well plates (Sarstedt, Nümbrecht, Germany) and chamber slides (Thermo Scientific ${ }^{\text {тм }}$ Nunc $^{\mathrm{TM}}$ Lab-Tek $^{\text {Tм}}$, Waltham, MA, USA)

\subsection{Chlamydial strains}

Two Chlamydia species were used during my experiments: C. trachomatis (serovar D, UW3/CX reference strain, and serovar L2, strain VR-577; ATCC) and C. pneumoniae (CWL029; ATCC). The Chlamydia strains were propagated and partially purified according to methods described previously, with modifications $[72,73]$.

Briefly, McCoy cells were treated with DEAE-dextran $(45 \mathrm{mg} / \mathrm{ml}$ in Hanks' balanced salt solution [HBSS]) and were infected with C. trachomatis serovar D, and after a 2-day incubation in culture medium (Minimal Essential Medium with Earle salts supplemented with $10 \%$ heat-inactivated fetal bovine serum [FBS], $0.5 \%$ glucose, $2 \mathrm{mmol} /$ liter L-glutamine, $1 \times$ nonessential amino acids, $8 \mathrm{mmol} /$ liter HEPES, $25 \mu \mathrm{g} / \mathrm{ml}$ gentamicin) in the presence of 1 $\mu \mathrm{g} / \mathrm{ml}$ cycloheximide, the infected cell layers were washed with phosphate-buffered saline (PBS), frozen, and covered with $50 \mu \mathrm{l} / \mathrm{cm}^{2}$ sucrose-phosphate-glutamic acid buffer (SPG). After 2 freeze-thaw cycles, the cells were collected and separated from the cell fragments by a 10-min centrifugation at $800 \mathrm{~g}$. C. trachomatis serovar L2 and C. pneumoniae were cultured in HEp-2 cells and partially purified and concentrated by centrifugation at $30,000 \mathrm{~g}$ as described previously [74]. The pelleted elementary bodies (EBs) were resuspended in SPG. Stocks of chlamydial EBs were aliquoted and stored, until use, in SPG at $-80^{\circ} \mathrm{C}$. McCoy $(C$. trachomatis) or HEp-2 (C. pneumoniae) cell monolayers grown on 13-mm-diameter coverslips and the titer of the infectious EBs was determined by inoculation of serial dilutions $\left(1: 10\right.$, to $\left.1: 10^{5}\right)$ of the EB preparation on the cells. Inoculated cells were centrifuged for $1 \mathrm{~h}$ at $800 \times g$, and after $24 \mathrm{~h}$ (C. trachomatis) or $48 \mathrm{~h}$ (C. pneumoniae) of culture in cycloheximidecontaining growth medium, the cells were fixed with precooled $\left(-20^{\circ} \mathrm{C}\right)$ acetone and stained with monoclonal anti-chlamydia lipopolysaccharide (LPS) antibody (AbD Serotec, Oxford, United Kingdom) and fluorescein isothiocyanate-labeled anti-mouse IgG (Sigma-Aldrich, St. 
Louis, MO). Under a UV microscope, the number of cells containing chlamydial inclusions was counted, and the titer was expressed as the number of inclusion forming units (IFU)/ml.

\subsection{Human herpes simplex virus}

Human herpes simplex virus type 2 reference strain (National Public Health Institute, Budapest) was used in this study. HHSV-2 strain was grown in Vero cells. Confluent monolayers of Vero cells were prepared in 6-well plates at $8 \times 10^{5}$ cells per well in RPMI 1640 medium, supplemented with $5 \%$ calf serum. The confluent monolayers were infected with 0.1 $\mathrm{ml}$ virus dilution $\left(1: 10\right.$ to $\left.1: 10^{9}\right)$ and after an adsorption period of $1 \mathrm{~h}$ at $37^{\circ} \mathrm{C}$, the cells were covered with an agar overlay medium. Incubation was continued for $96 \mathrm{~h}$ and then the cultures were overlaid with an agar medium containing $0.012 \%$ neutral red. After further incubation at $37^{\circ} \mathrm{C}$, the plaque numbers were determined on the following day. The virus titer was expressed in plaque forming units (PFU). [75]

\subsection{3-(4,5-dimethyl-2-thiazolyl)-2,5-diphenyl-2H-tetrazolium bromide (MTT) assay}

We determined the toxicological profile of NPs using a standard MTT assay [76,77]. MTT assay was performed to characterize the maximum non-toxic concentration of the NPs. HeLa 229 (ATCC) cells were transferred into the wells of the 96-well plate (Sarstedt, Nümbrecht, Germany) at a density of $6 \times 10^{4}$ cells/well in $100 \mu \mathrm{l}$ of minimal essential medium (MEM) with Earle salts supplemented with 10\% heat-inactivated fetal bovine serum (FBS) (Gibco; Germany), 2 mmol/1 L-glutamine, 1x MEM vitamins, 1x non-essential amino acids, $0.005 \%$ Na-pyruvate, $25 \mu \mathrm{g} / \mathrm{ml}$ gentamycin, $1 \mu \mathrm{g} / \mathrm{ml}$ amphotericin-B (SIGMA, St. Louis, MO, USA). The plates were incubated for $1 \mathrm{~h}$ at room temperature (RT) and then overnight at $37{ }^{\circ} \mathrm{C}, 5 \% \mathrm{CO}_{2}$. The next day, when the cells reached a $\sim 90 \%$ confluency, the medium was supplemented with the serial 2-fold dilutions of the NPs in three parallel wells for each concentration. After a $48 \mathrm{~h}$ incubation, $10 \mu \mathrm{l}$ of the MTT (SIGMA) labelling reagent (final concentration $0.5 \mathrm{mg} / \mathrm{ml}$ ) was added to each well and the plate was incubated for $4 \mathrm{~h}$ at $37{ }^{\circ} \mathrm{C}, 5 \% \mathrm{CO}_{2}$. After the incubation, $100 \mu \mathrm{l}$ of the lysis solution $(10 \% \mathrm{SDS}$ in $1 \mathrm{~N} \mathrm{HCl})$ was added to each well and the plate was allowed to stand overnight in the incubator at $37{ }^{\circ} \mathrm{C}, 5 \%$ $\mathrm{CO}_{2}$. The next day, the optical density of the wells was measured by a microtiter plate reader 
(Labsystems Multiskan Ex 355, Thermo Fisher Scientific, Waltham, MA USA). The absorbance of the formazan product was measured at $540 \mathrm{~nm}$.

\subsection{Preparation of silver nanoparticles (AgNPs)}

The AgNPs were prepared according to our previous preparation procedure [78]. Sodium borohydride and sodium citrate were used as reducing and stabilizing agents, respectively. The initial concentration of the prepared aquas AgNPs dispersion was $100 \mathrm{ppm}$ $(0.92 \mathrm{mM})$ and the average particle size determined by TEM was $20.2 \pm 8.34 \mathrm{~nm}$.

\subsection{Preparation of the silver- modified $\mathrm{TiO}_{2}$ particles $\left(\mathrm{Ag}-\mathrm{TiO}_{2}\right)$}

Five grams of $\mathrm{P} 25 \mathrm{TiO}_{2}$ (Degussa-Evonik) was dispersed in $100 \mathrm{ml}$ of double distilled water; then, $40 \mathrm{ml}$ of $57.9 \cdot 10^{-3} \mathrm{mM} \mathrm{AgNO}_{3}$ (Reanal) solution was added to the suspension, and it was vigorously stirred. The $\mathrm{pH}$ was adjusted to 7.2, and then, $60 \mathrm{ml} 38.6 \mathrm{mM} \mathrm{NaBH} 4$ (Reanal) solution was added dropwise to the suspension. The obtained $\mathrm{Ag}-\mathrm{TiO}_{2}$ suspension was stirred for $60 \mathrm{~min}$, washed with double distilled water, centrifuged, and dried [71].

\subsection{Transmission electron microscopy measurements of $\mathrm{TiO}_{2^{-}}, \mathrm{Ag}$ - and $\mathrm{TiO}_{2^{-}}$}

\section{Ag NPs}

The morphology and the particle size of the prepared $\mathrm{TiO}_{2^{-}}, \mathrm{Ag}-$ and $\mathrm{TiO}_{2}-\mathrm{Ag}$ NPs were examined by a transmission electron microscope (TEM). The investigation was performed using a Tecnai G2 20 X-Twin type instrument (FEI, Hillsboro, OR, USA), operating at an acceleration voltage of $200 \mathrm{kV}$. The microscope was equipped with a Megaview II digital camera. For TEM measurements the samples were sonicated in distilled water before being dropped on a copper mounted lacy carbon film (200 Mesh) and dried.

\subsection{Surface charge measurements of the $\mathrm{TiO}_{2-}, \mathrm{Ag}-$ and $\mathrm{TiO}_{2}-\mathrm{Ag} \mathrm{NPs}$}

Surface charge values of the NPs were measured by means of a PCD-04 particle charge detector (Mütek Analytic GmbH, Herrsching, Germany) with manual titration. Under a titration process the surface charge of the $\mathrm{TiO}_{2-}, \mathrm{Ag}$ - and $\mathrm{TiO}_{2}-\mathrm{Ag}$ NPs were compensated with hexadecylpyridinium chloride $(\mathrm{HDPCl})$ as opposite charged surfactants with concomitant streaming potential measurements. $10 \mathrm{ml}$ of $100 \mu \mathrm{g} / \mathrm{ml}$ particle suspension in a 
sucrose-phosphate-glutamic acid buffer (SPG, pH 7.4, $0.25 \mathrm{M}$ sucrose, $10 \mathrm{mM}$ sodium phosphate, $5 \mathrm{nM}$ glutamic acid in a distilled water) medium was measured in the particle charge detector at $\mathrm{pH}=7.4$. In view of the amount of the $0.01 \%$ surfactant solution added at the charge compensation point (streaming potential $=0 \mathrm{mV}$ ), the equimolar amount of surfactant was calculated and specified to the amount of particles (meq/100 g). All experiments were repeated three times.

\subsection{Investigation of the impact of NPs on $C$. trachomatis growth in HeLa cells}

HeLa 229 (ATCC) cells were transferred into the wells of the 96-well plate (Sarstedt, Nümbrecht, Germany) at a density of $6 \times 10^{4}$ cells/well in $100 \mu 1$ of minimal essential medium (MEM) with Earle salts supplemented with 10\% heat-inactivated fetal bovine serum (FBS) (Gibco; Germany), 2 mmol/1 L-glutamine, 1x MEM vitamins, 1x non-essential amino acids, 0,005\% Na-pyruvate, $25 \mu \mathrm{g} / \mathrm{ml}$ gentamycin, $1 \mu \mathrm{g} / \mathrm{ml}$ Fungisone.)

$\mathrm{TiO}_{2-}, \mathrm{Ag}$ - and $\mathrm{TiO}_{2}-\mathrm{Ag}$ NPs were prepared in a physiological salt solution and diluted in SPG. C. trachomatis elementary bodies were incubated with the NPs for 1 hour at $37^{\circ} \mathrm{C}$. Incubations were performed in the dark in order to avoid the photocatalytic effect of $\mathrm{TiO}_{2}$. Concentrations ranging from 100 to $0.024 \mu \mathrm{g} / \mathrm{ml}$ for $\mathrm{TiO}_{2^{-}}, \mathrm{TiO}_{2}-\mathrm{Ag}$ - and $0.5-0.001 \mu \mathrm{g} / \mathrm{ml}$ for Ag NPs with 4-fold dilutions were tested. Before infection the cells were washed twice with phosphate-buffered saline (PBS) and the cells were incubated with the treated and untreated C. trachomatis (multiplicity of infection (MOI) 8) for 1 hour, at $37{ }^{\circ} \mathrm{C}$ with a $5 \% \mathrm{CO}_{2}$ atmosphere. After infection the cells were washed twice with $200 \mu 1 /$ well of PBS, then the culture medium was supplemented with $1 \mu \mathrm{g} / \mathrm{ml}$ cycloheximide. The plates were incubated at $37^{\circ} \mathrm{C}, 5 \% \mathrm{CO}_{2}$ for $48 \mathrm{~h}[77]$.

\subsection{Investigation of the impact of NPs on HSV-2 growth in Vero cells}

Vero cells (ATCC) were transferred to the wells of a 96-well plate at a density of $6 \times 10^{4}$ cells/well in $100 \mu \mathrm{l}$ of Dulbecco's Modified Eagle's Medium (DMEM) (Sigma; USA) containing 5\% fetal bovine serum (FBS) (Gibco; Germany), 0.14\% sodium bicarbonate, 100 $\mathrm{U} / \mathrm{mL}$ penicillin, $100 \mu \mathrm{g} / \mathrm{mL}$ streptomycin sulfate, and $250 \mu \mathrm{g} / \mathrm{mL}$ amphotericin B. Preincubation was performed as described for C. trachomatis. Before infection the cells were washed twice with PBS, then the cells were incubated with the treated and untreated HSV-2 
(MOI 0.1) for $1 \mathrm{~h}$ at $37{ }^{\circ} \mathrm{C}, 5 \% \mathrm{CO}_{2}$. After the infection the cells were washed twice with PBS and the plates were incubated for 12 hours at $37{ }^{\circ} \mathrm{C}, 5 \% \mathrm{CO}_{2}$.

\subsection{Monitoring the growth of $C$. trachomatis and HSV-2 by direct quantitative PCR (qPCR)}

The supernatants of the cells were removed and the cells were washed with PBS twice. After the second wash $100 \mu$ Milli-Q (MQ) water (Millipore, Billerica, MA, USA) was added to each well and subjected to two freeze-thaw cycle with a quick freezing $\left(-80{ }^{\circ} \mathrm{C}, 15 \mathrm{~min}\right)$ and a quick thawing on a plate shaker at room temperature (RT). The cell lysates were thoroughly mixed including the edges of the wells using a multichannel pipette. The mixed lysates were used as a template in the qPCR [79].

The quantitative PCR (qPCR) was performed using the Bio-Rad CFX96 real time system. The SsoFast EvaGreen qPCR Supermix (Bio-Rad, Hercules, CA, USA) master mix and $C$. trachomatis pykF gene specific primer pair were used [79]. The primer sequences were the following:

$$
p y k F-F: 5^{\prime}-\mathrm{GTTGCCAACGCCATTTACGATGGA-3',}
$$$$
\text { pykF-R:5'-TGCATGTACAGGATGGGCTCCTAA-3'. }
$$

$5 \mu \mathrm{l}$ SsoFast EvaGreen supermix, 1-1 $\mu \mathrm{l}$ forward and reverse primers (10 pmol each), $1 \mu \mathrm{l}$ template and $2 \mu \mathrm{l} \mathrm{MQ}$ water was the consistent of the PCR mixture with a $10 \mu \mathrm{l}$ final volume. 40 PCR cycles of $20 \mathrm{~s}$ at $95{ }^{\circ} \mathrm{C}$ and $1 \mathrm{~min}$ at $64{ }^{\circ} \mathrm{C}$ were performed with a $10 \mathrm{~min}$ at $95{ }^{\circ} \mathrm{C}$ polymerase activation for the first step.

The fluorescence intensity was measured at the end of the annealing-extension step. The melting curve analysis was used to get the specificity of amplification. For each PCR, the cycle threshold $(\mathrm{Ct})$ corresponding to the cycle where the amplification curve crossed the base line was determined. For the quantitative measurement of HSV-2 growth a similar qPCR method was used as that applied for $C$. trachomatis, with HSV-2 gD2 gene specific primer pair: $\quad g D 2-F: 5^{\prime}$-TCAGCGAGGATAACCTGGGA-3', $g D 2-R$ 5'-GGGAGAGCGTACTTGCAGGA-3'.

Student's t-test was used to evaluate the statistical differences between the samples (3 biological replicates for each condition). 


\subsection{Culture of Chlamydiae on chamber slide}

Chamber slides with 16 wells consisting of a removable, plastic chamber attached to a specially treated standard glass slide were used to culture host cells for infection with Chlamydia. The slides were treated with $100 \mu \mathrm{l} /$ well $0.01 \%$ poly-L-lysine or Percoll (Pharmacia LKB, Biotechnology AB, Uppsala, Sweden) at RT for 15-20 min in order to optimize cell attachment. McCoy cells were transferred into the wells of the chamber slides at a density of $3 \times 10^{4}$ cells/well in $100 \mu \mathrm{l}$ of culture medium (see above). The slides were incubated for $1 \mathrm{~h}$ at room temperature in order to reduce the edge effect $[80,81]$ and then overnight at $37{ }^{\circ} \mathrm{C}$ under a $5 \% \mathrm{CO}_{2}$ atmosphere to obtain a $90 \%$ confluent cell layer. For $C$. trachomatis serovar D infection, the wells were washed with $200 \mu \mathrm{l} /$ well of HBSS, and then a $1 \%$ DEAE-dextran solution ( $80 \mu \mathrm{l} /$ well) was added to all wells and the slides were incubated for $15 \mathrm{~min}$ at RT. The DEAE-dextran solution was removed and the cells were infected at a MOI of 1 IFU/cell in each well or with serial 2-fold dilutions of stock in SPG starting with 1 IFU/cell. SPG was added to similarly treated control wells. The chamber slides were incubated at RT in a vertical shaker $(180 \mathrm{rpm})$ for $2 \mathrm{~h}$. The cells were infected with $C$. trachomatis serovar L2 at MOIs ranging from $1 \mathrm{IFU} /$ cell to 1:64 IFU/cell in SPG and were incubated at $35{ }^{\circ} \mathrm{C}$ under $5 \% \mathrm{CO}_{2}$ for $2 \mathrm{~h}$ without DEAE-dextran pretreatment. The DEAEdextran treatment was used for $C$. pneumoniae infection or the slides with the $C$. pneumoniae stock at MOIs ranging from 1:8 to $1: 512 \mathrm{IFU} /$ cell were centrifuged at $400 \times g$ for $60 \mathrm{~min}$ at RT. The EB-containing inocula in the wells were replaced with a culture medium containing 1 $\mu \mathrm{g} / \mathrm{ml}$ cycloheximide, after the infection. The slides were incubated at $37{ }^{\circ} \mathrm{C}$ under $5 \% \mathrm{CO}_{2}$ for 24 or $48 \mathrm{~h}$ after infection with C. trachomatis serovars D and L2 or C. pneumoniae, respectively, and the cells were fixed for immunofluorescence staining.

\subsection{Inhibition of chlamydial growth with antibiotics and IFN- $\gamma$}

Moxifloxacin (Avelox; Bayer Pharma AG) diluted in culture medium and tetracycline hydrochloride powder (Sigma-Aldrich) dissolved in distilled water were used. Concentration ranges of 0.25 to $0.004 \mu \mathrm{g} / \mathrm{ml}$ for moxifloxacin and of 0.04 to $0.0006 \mu \mathrm{g} / \mathrm{ml}$ for tetracycline with 2-fold dilutions were tested. The stock solution of antibacterial drug candidate PCC00213 (10 mg/ml) was prepared in dimethyl sulfoxide (DMSO) and was diluted 2-fold in DMSO from $0.156 \mathrm{mg} / \mathrm{ml}$. Cycloheximide-containing culture medium was prepared by a 100fold dilution of the DMSO-diluted compound, resulting in a series of concentrations ranging 
from 100 to $1.56 \mu \mathrm{g} / \mathrm{ml}$ with a $1 \%$ DMSO content. After infection of McCoy cells with $C$. trachomatis serovar D (MOI 1), the culture medium with cycloheximide was supplemented with the serial 2-fold dilutions of the respective antibiotics and was added to duplicate wells. Control infected wells were cultured without adding any antibiotics; for PCC00213, 1\% DMSO-containing medium was added to the control wells. Murine IFN- $\gamma$ (Peprotech, Rocky Hill, NJ) was reconstituted according to the manufacturer's instructions, and the $20,000 \mathrm{U} / \mathrm{ml}$ stock solution was stored at $-80{ }^{\circ} \mathrm{C}$ until use. On the day before infection, the cell layers were treated with serial 2-fold dilutions of murine IFN- $\gamma$ over the concentration range of 100 to $0.046 \mathrm{IU} / \mathrm{ml}$. Human IFN- $\gamma$ (Peprotech, Rocky Hill, NJ) was also added over a concentration range of $100 \mathrm{IU} / \mathrm{ml}$ to $1.5 \mathrm{IU} / \mathrm{ml}$, as a control. After the infection procedure, IFN- $\gamma$ diluted in cycloheximide-free medium was added at the same concentration as that used for the pretreatment of cells before infection.

\subsection{4 $\mathrm{TiO}_{2} \mathrm{NP}$ treatment of HeLa cells and monitoring of $C$. trachomatis growth on a chamber slide system}

C. trachomatis (MOI 8) was preincubated with $\mathrm{TiO}_{2}$ NPs for 1 hour at $37{ }^{\circ} \mathrm{C}$ with a concentration range from 100 to $3.12 \mu \mathrm{g} / \mathrm{ml}$ with 2-fold dilutions. Incubations were performed in the dark in order to avoid the photocatalytic effect of $\mathrm{TiO}_{2}$. As controls, two wells of HeLa cells infected with untreated C. trachomatis and two wells with uninfected but treated (100 $\mu \mathrm{g} / \mathrm{ml} \mathrm{TiO}_{2}, 1 \mathrm{~h}, 37^{\circ} \mathrm{C}$ ) HeLa cells were included. After the cells were washed twice with PBS and were infected/incubated with $C$. trachomatis or NPs for 1 hour, at $37{ }^{\circ} \mathrm{C}, 5 \% \mathrm{CO}_{2}$. After the infection, the cells were washed twice with $200 \mu \mathrm{l} /$ well of PBS, and the culture medium was supplemented with $1 \mu \mathrm{g} / \mathrm{ml}$ cycloheximide. The plates were incubated at $37{ }^{\circ} \mathrm{C}, 5 \% \mathrm{CO}_{2}$ for $48 \mathrm{~h}$.

\subsection{Immunofluorescent labeling and scanning}

Cells in chamber slides infected with $C$. pneumoniae and $C$. trachomatis were examined after immunofluorescent staining. After removing the culture medium from the slides, the cells were washed twice with PBS (200 $\mu \mathrm{l} /$ well). Then, the chamber structure was detached from the slides and the cells were fixed with precooled $100 \%$ acetone for $10 \mathrm{~min}$ at $-20{ }^{\circ} \mathrm{C}$. Anti-chlamydia LPS antibody (AbD Serotec, Oxford, United Kingdom) was labeled with Alexa-647, and a 1:200 dilution was used for the detection of chlamydial inclusions. 
After incubation for $1 \mathrm{~h}$ at $37{ }^{\circ} \mathrm{C}$, the cells were washed three times with PBS for 7 min each time and finally with distilled water. Fluorescence signals were analyzed with an Axon GenePix Personal 4100A DNA chip scanner and GenePix Pro (version 6.1) software (Molecular Devices, Sunnyvale, CA) using the Cy5 channel and a 5- $\mu \mathrm{m}$ resolution.

\subsection{Image processing}

The scanned images were about 50- to 60-MB single-image 16-bit tiff files with an intensity dynamic range of 4 orders of magnitude. The images were processed by ChlamyCount in two phases: preprocessing and analysis. In the preprocessing phase, after loading the image, the contrast was enhanced by performing the histogram normalization method of ImageJ. Afterward, the regions of interest (ROIs) containing the areas of the 16 wells of the scanned image were cropped. The cropping method was specifically designed for the 16-well Lab-Tek chamber slide system. The image of each well was processed independently, in the following steps. To reduce noise effects, pixels of the ROI below a predefined threshold were eliminated using the ImageJ threshold operation. The default intensity threshold was set to 15,000 , a value which was empirically determined. However, depending on the fluorescent antibody and scanner type used, the image intensity may change; hence, the user can manually change the inclusion intensity and area thresholds. In a further noise-reduction step, a grey-scale morphological opening (a morphological erosion followed by a dilation) was applied, using the minimum and maximum filters of ImageJ on a 3-by-3 window.

In the analysis phase, the images of each well were processed independently. First, a binarized copy of the result of the preprocessing phase was produced. Then, the ImageJ analyze particles function was called to encounter and outline the particles (a potential inclusion or inclusions) in the well. Since confluent inclusions of various shapes could occur, no size or circularity constraints were set during the process. In the next step, the median area of the particles was computed, and particles having an area greater than the calculated median area were further processed. If the perimeter of the particle was less than 500 pixels, then the particle was decomposed by Voronoi tessellation using the local grey-scale minima as seeds and the Euclidean distance. However, no splitting was performed if the perimeter of the particle was greater than 500 pixels, because those regions were likely to represent areas of potentially aspecific labeling of the background and/or host cells. Setting a higher-intensity 
threshold in the preprocessing step could reduce the occurrence of such areas. After the splitting step, the ImageJ analyze particles function was again called to identify the final number of particles and to find their boundaries, which were highlighted in red on the original grey-scale image. Finally, the result of the analysis was reported in txt, xls, and pdf files. The .pdf file contains the numerical results and the processed images of the 16 areas. It should be noted that for easier visibility of the inclusions on the small-scale figures in this paper, the images of the 16 areas were further contrast enhanced using the duotone feature of PhotoFiltre image-processing software.

\subsection{Confocal microscopy and imaging}

Confocal laser scanning microscopy was performed using an Olympus FV1000 confocal laser scanning microscope (Olympus Life Science Europe GmbH, Hamburg, Germany). The microscope configuration was the following: objective lenses, UPLSAPO $\times 10$ (numerical aperture [NA], 0.4), UPLSAPO $\times 20(\mathrm{NA}, 0.75)$, and LUMPLFL $\times 40(\mathrm{NA}, 0.8)$; sampling speed, 4 or $8 \mu \mathrm{s} /$ pixel; line averaging, $2 \times$; confocal aperture, $200 \mu \mathrm{m}$; image dimension, 512 by 512 pixels; scanning mode, sequential unidirectional; excitation, 633-nm HeNe laser; and laser transmissivity, 45\%. Alexa Fluor 647 was detected between 645 and $745 \mathrm{~nm}$. Transmitted light images were also captured and paired with each fluorescence image using a $633-\mathrm{nm}$ laser. Using a $\times 10$ objective, 16 successive images were captured to encompass the full diameter of each well of the 16-well chamber slide. Images were stitched together to make an image strip of 512 by 8,192 pixels using the import image sequence and make montage functions of ImageJ software. Infected cells were identified and manually scored on these composite images. Since the area of the image strip is 12.2 times smaller than the area of the whole well, to estimate the approximate total number of inclusions per well, the counted inclusions were multiplied by 12.2. For close-up analyses, microscopy slides were mounted with Fluoromount-G antifade mounting solution (Southern Biotech, Birmingham, AL) and a $\times 40$ immersion objective was used to capture images. 


\subsection{Transmission electron microscopy measurements of early interaction of $\mathrm{TiO}_{2}$ NPs with HeLa and Vero cells}

HeLa 229 and Vero cells were transferred to the wells of the 6-well plate at a density of 2 $\times 10^{6}$ cells/well in culture medium (see above). Before the treatment, the cells were washed twice with PBS. The cells were incubated with $100 \mu \mathrm{g} / \mathrm{ml}$ of $\mathrm{TiO}_{2}\left(1 \mathrm{~h}, 37{ }^{\circ} \mathrm{C}, 5 \% \mathrm{CO}_{2}\right)$. After the incubation, the cells were washed twice with $3 \mathrm{ml} /$ well of PBS, then $300 \mu \mathrm{l}$ of Trypsin-Versene (SIGMA) was added to each well. The detached cells were centrifuged and the cell pellets were fixed in $600 \mu 1$ glutaraldehyde. Cell pellets were embedded in Embed 812 (EMS, USA). The 70-nm thin sections were prepared with an Ultracut S ultra-microtome (Leica, Austria). After staining with uranyl acetate and lead citrate, the sections were observed with a JEM-1400 plus electron microscope (JEOL, Peabody, MA, USA). 


\section{Results}

\subsection{ChlamyCount software}

McCoy epithelial cells grown on a 16-well chamber slide were used for chlamydial infection. We removed the chamber at 24 or $48 \mathrm{~h}$ postinfection (p.i.), depending on the chlamydial strain, fixed the host cells, and stained the chlamydial inclusions with Cy5 analogue Alexa 647-labeled anti-chlamydial LPS antibody. The stained inclusions were scanned with an Axon GenePix 4100 DNA chip scanner. The scanner is capable of scanning Cy3- or Cy5-labeled spots on a regular microscope glass slide with a maximum resolution of $5 \mu \mathrm{m}$, which is comparable to the size of a chlamydial inclusion (Figure 4.).

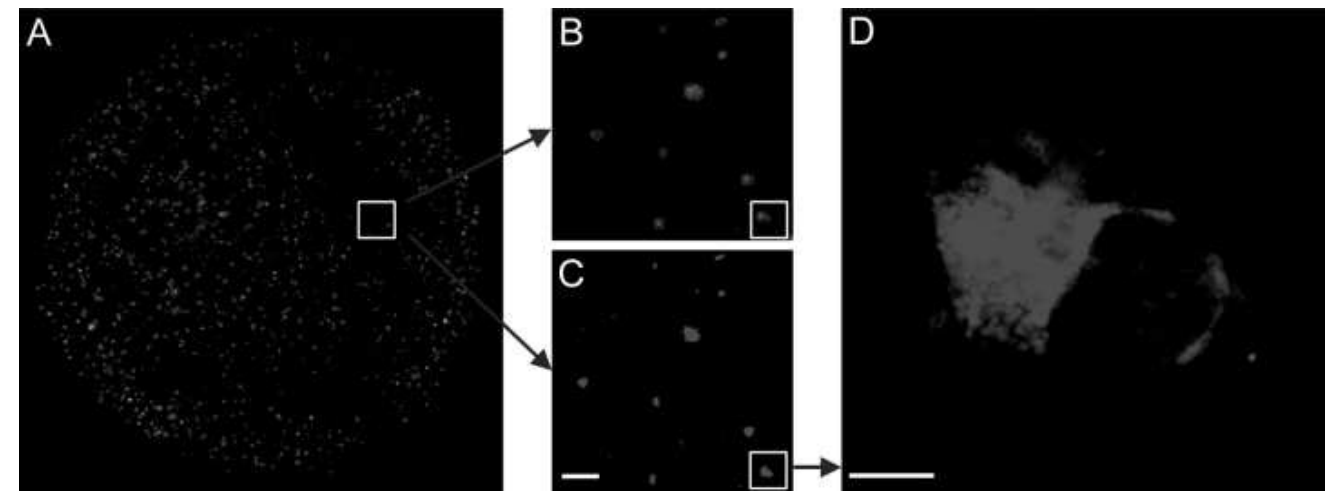

Figure 4. Comparison of the images produced by a DNA chip scanner and confocal microscopy. (A) C. trachomatis serovar D-infected McCoy cells grown in a 16-well plastic chamber attached to a glass slide. After fixation, chlamydial inclusions are fluorescently labeled and scanned by a DNA chip scanner at a 5- $\mu \mathrm{m}$ resolution. A scanned image of a well of the 16-well chamber slide is shown. (B) Magnified portion (boxed area of panel A) of the scanned image. (C) The same boxed area from panel A visualized by fluorescent confocal laser scanning microscopy. Bar $=100 \mu \mathrm{m}$. (D) Further magnification of the fluorescent structure at the lower right of panels $\mathrm{B}$ and $\mathrm{C}$ reveals a single infected cell. Bar $=10 \mu \mathrm{m}$.

The ChlamyCount software was used to process the scanned image. The thresholds for the minimum intensity and size of the inclusion are changeable by the user; otherwise, fixed threshold values are applied. The two threshold values are the only parameters that can be adjusted by the user; all the subsequent steps are automatic. If the user adjusts the intensity and/or area threshold, the effect of the adjustment can immediately be seen by a magnified quarter of the primary well and the well in the lowest left-hand side. In the next step, ChlamyCount automatically crops the 16 areas containing the host cells from the complete image. For each area, ChlamyCount processes the images as follows: 
- the pixels with low intensity values are likely noise; therefore, they are eliminated by thresholding the image with an intensity and area threshold value;

- regions having an area greater than the median of the area of all regions (the suspected size of a single inclusion) are split by finding the local maxima in the regions and then assigning each point to the same closest maximum to form smaller regions;

- $\quad$ the identified particles are encountered and their margins are determined

After the image analysis, ChlamyCount provides a detailed .txt and .xls output of the 16 areas with the inclusion counts; the total areas above the threshold, and, if confluent, highintensity areas were detected and could not be dissected to individual inclusions by the software; and the total area/median area ratio is also provided. The median area size is suspected to be the area of an individual inclusion when the MOI is not high, i.e., equal to or below 1 . The third output file is a .pdf file with the above-mentioned numerical results and the processed images of the 16 areas (Figure 5.). A usual scanning time is about $10 \mathrm{~min}$, and the image analysis time is about 1 to $5 \mathrm{~min}$.

A

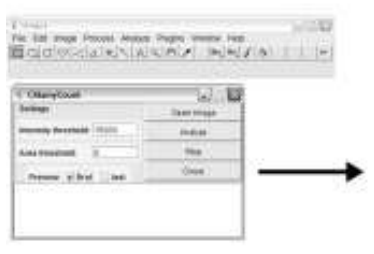

B

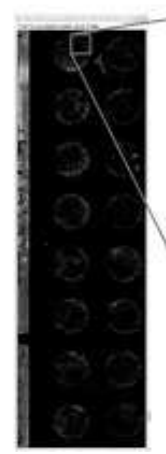

C

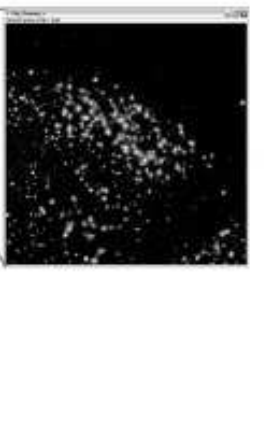

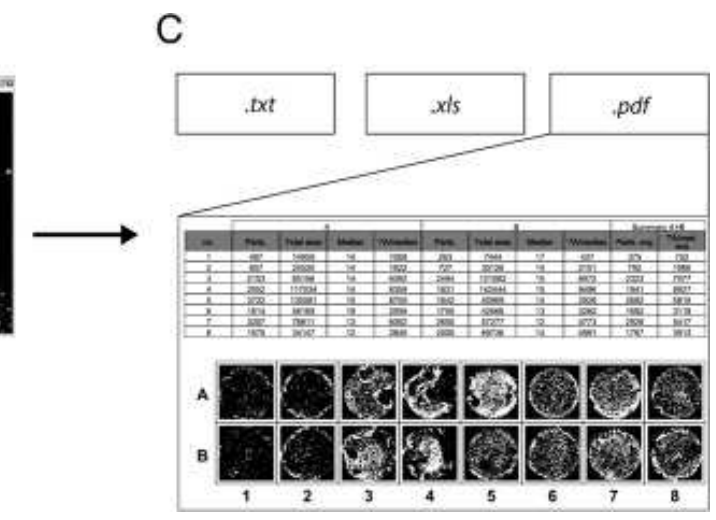

Figure 5. ChlamyCount image adjustments and report. (A) Infected host cells are grown in a 16-well chamber slide. Chlamydial inclusions are stained by direct immunofluorescence and scanned by a DNA chip scanner. Before image analysis, the user can adjust the inclusion intensity and area thresholds for detection. (B) The effect of the applied threshold changes on the number and location of the detected inclusions can be readily checked by magnification of the quadrants at the left uppermost and lowest wells of the chamber. On the basis of the applied thresholds, ChlamyCount performs the image analysis. (C) ChlamyCount reports the numerical data as .txt, .xls, and .pdf files. The .pdf file contains the numerical data as well as the images of the 16 scanned areas. 


\subsection{Measuring the dynamic range of detection of $C$. trachomatis serovar D, $C$. trachomatis serovar L2, and C. pneumoniae}

The ChlamyCount system was tested on McCoy cells infected with a 1:2 dilution series of $C$. trachomatis serovar D, $C$. trachomatis serovar L2, and $C$. pneumoniae. The $C$. trachomatis serovar D infection was performed using the DEAE-dextran method, the $C$. trachomatis serovar L2 infection was performed without DEAE dextran, and the $C$. pneumoniae infections were performed by centrifugation $(400 \times g, 60 \mathrm{~min}, \mathrm{RT})$. Since both $C$. trachomatis serovars have a faster developmental cycle, the inclusion counting was performed after 24 h p.i., while for $C$. pneumoniae it was performed at $48 \mathrm{~h}$ p.i. The highest MOI was 8 , but between MOIs of 8 and 1, the infected areas were greatly confluent and ChlamyCount could not analyze these areas efficiently. For further experiments, the starting MOI was either 1 (C. trachomatis serovars D and L2) or 1:8 (C. pneumoniae), and 6 additional 1:2 dilutions were performed in duplicate. The last two wells contained uninfected McCoy cells.

We could measure a high correlation $\left(R^{2}=0.95\right.$ to 0.98$)$ between the measured Chlamydia inclusion count with all three Chlamydia species and the theoretical inclusion count calculated from the 1:2 dilution curve. The other two calculated values, namely, the total area above the intensity threshold and the total area/median area ratios, also highly correlated with the calculated theoretical values. The inclusion counts closely followed the theoretical inclusion counts between an MOI of 1 and MOIs of 1:8 to 1:16, when no centrifugation was used for infection (C. trachomatis serovars D and L2), resulting in an approximately 1-log-unit dynamic range of the ChlamyCount system. The detected inclusion counts did not change substantially after an MOI of 1:16, marking the lower threshold of detection. The centrifugation was more efficient and allowed us to use lower MOIs for $C$. pneumoniae infection. Nevertheless, we experienced leakage in about 25 to $30 \%$ of the chambers; therefore, this infection method was not used for other experiments (Figure 6.). 

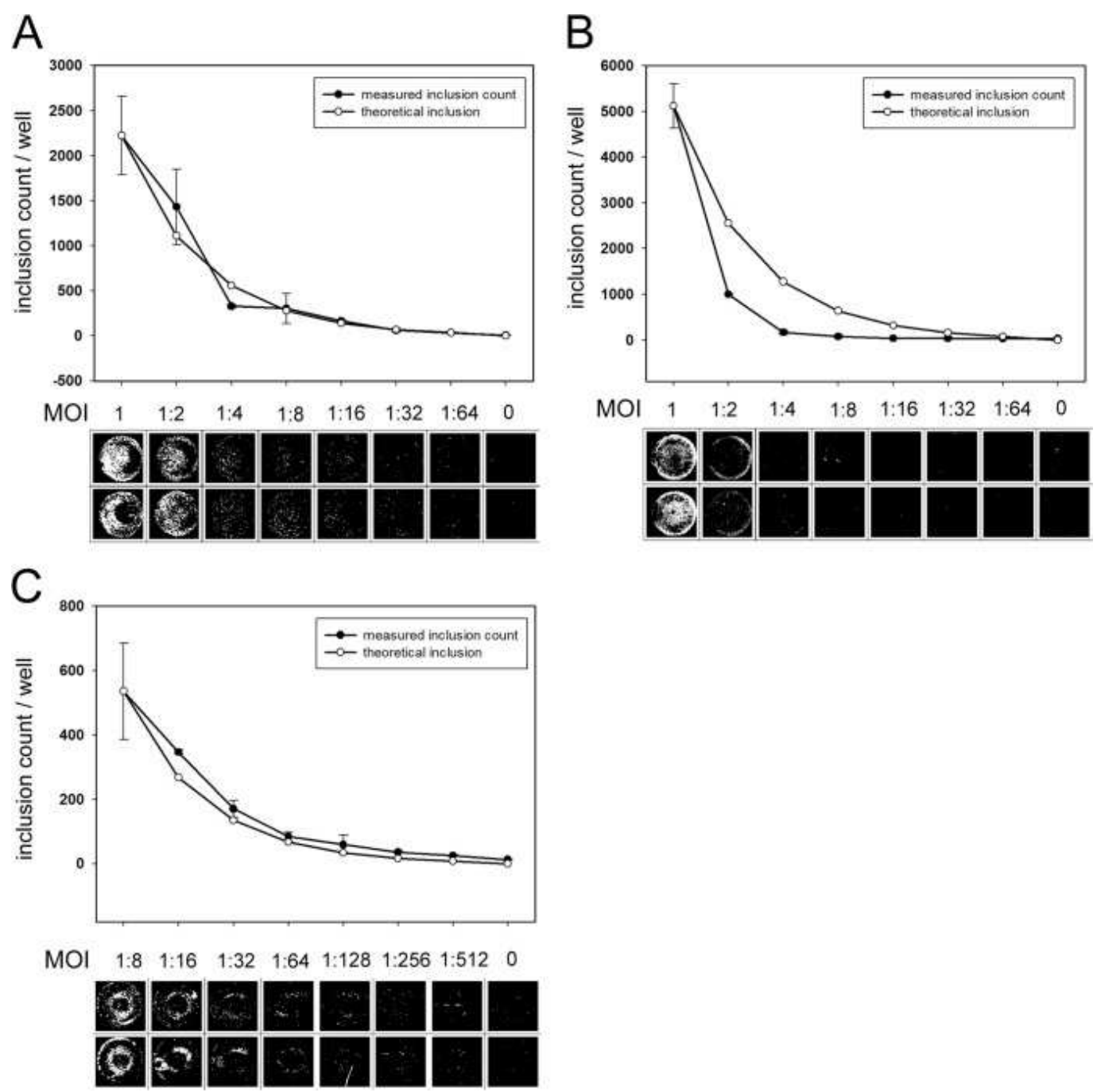

Figure 6. Detection of chlamydial inclusions. McCoy cells were infected with serially diluted $C$. trachomatis serovar D (A), C. trachomatis serovar L2 (B), and C. pneumoniae (C). C. pneumoniae infections were performed by centrifugation $(400 \times g, 60 \mathrm{~min}, \mathrm{RT})$. Each infection at a particular MOI was performed in parallel wells. MOIs are shown as simple fractions instead of decimal numbers in order to follow the serial dilutions more easily. The last two wells were uninfected. The images of scanned and ChlamyCount-processed wells and the numerical data are shown for each species and serovar. For easier comparison of the theoretical and measured inclusion counts, the first theoretical inclusion count was made the same as the first measured inclusion count. Data are means \pm standard deviations for the parallel wells.

\subsection{Assessment of the minimal inhibitory concentration (MIC) of moxifloxacin, tetracycline, and the novel antichlamydial compound PCC00213 for $C$. trachomatis serovar D growth}

We tested whether ChlamyCount was capable of determining the MICs of the known antichlamydial antibiotics moxifloxacin and tetracycline. The $C$. trachomatis serovar D 
moxifloxacin MIC was previously characterized to be 0.03 to $0.05 \mu \mathrm{g} / \mathrm{ml}$ [82-84]. We performed C. trachomatis serovar D infections (MOI 1) in the presence of moxifloxacin at concentrations ranging from $0.25 \mu \mathrm{g} / \mathrm{ml}$ to $0.04 \mu \mathrm{g} / \mathrm{ml}$. Our experiments showed (Figure 7 . A) that $C$. trachomatis could grow in the presence of moxifloxacin up to a concentration of $0.015 \mu \mathrm{g} / \mathrm{ml}$ but was inhibited at a concentration of $0.031 \mu \mathrm{g} / \mathrm{ml}$, resulting in an MIC value of $0.031 \mu \mathrm{g} / \mathrm{ml}$. Tetracyclines are first-choice antibiotics for the treatment of chlamydial infections. The tetracycline and doxycycline MICs for $C$. trachomatis serovar D were previously characterized to be 0.03 to $0.15 \mu \mathrm{g} / \mathrm{ml}[82,85,86]$. We performed $C$. trachomatis serovar D infections (MOI 1) in the presence of tetracycline at concentrations ranging from $0.04 \mu \mathrm{g} / \mathrm{ml}$ to $0.0006 \mu \mathrm{g} / \mathrm{ml}$. Our experiments revealed (Figure 7. B) that C. trachomatis could grow in the presence of tetracycline up to a concentration of $0.01 \mu \mathrm{g} / \mathrm{ml}$ but was inhibited at a concentration of $0.02 \mu \mathrm{g} / \mathrm{ml}$, resulting in a MIC value of $0.02 \mu \mathrm{g} / \mathrm{ml}$. To determine the MIC of the novel antichlamydial compound PCC00213, ChlamyCount was used as well. C. trachomatis could grow in the presence of PCC00213 up to a concentration of $3.1 \mu \mathrm{g} / \mathrm{ml}$ but was inhibited at a concentration of $6.2 \mu \mathrm{g} / \mathrm{ml}$, resulting in a MIC value of 6.2 $\mu \mathrm{g} / \mathrm{ml}$ (Figure 7. C). We have to note that parallel MTT-based host cell viability assays showed that the antichlamydial effect of PCC00213 was partially due to the inhibition of host cell metabolism. Parallel to the ChlamyCount-based MIC determination, we investigated the same slides with fluorescence microscopy and determined the inclusion counts in each chamber. The absolute inclusion counts were generally higher when we applied ChlamyCount, but there was a high correlation between the two inclusion counts $\left(\mathrm{R}^{2}=0.94\right.$ to 0.98) (Figure 7. A, C, D). Notably, the MIC values determined by the ChlamyCount and manual methods were identical for all three tested compounds. 
A

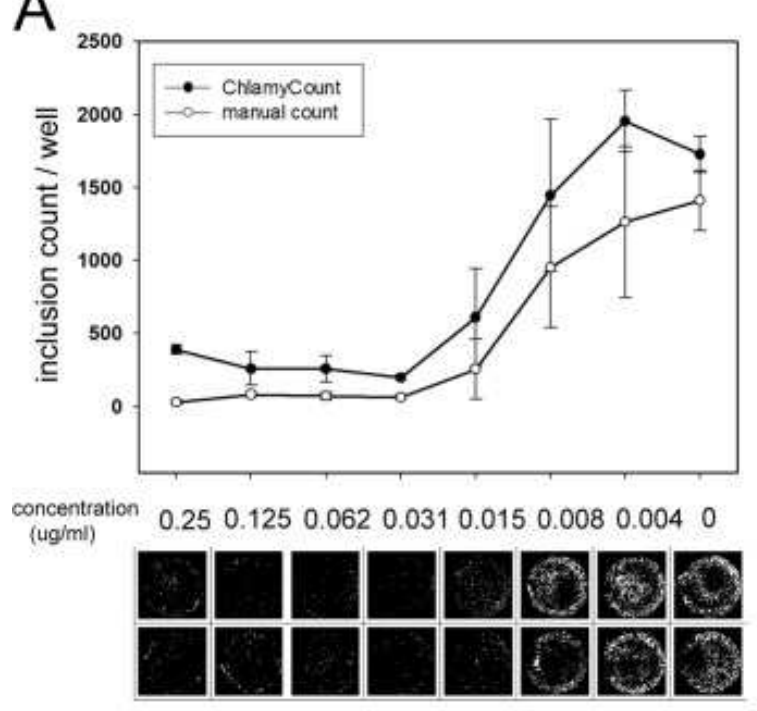

C

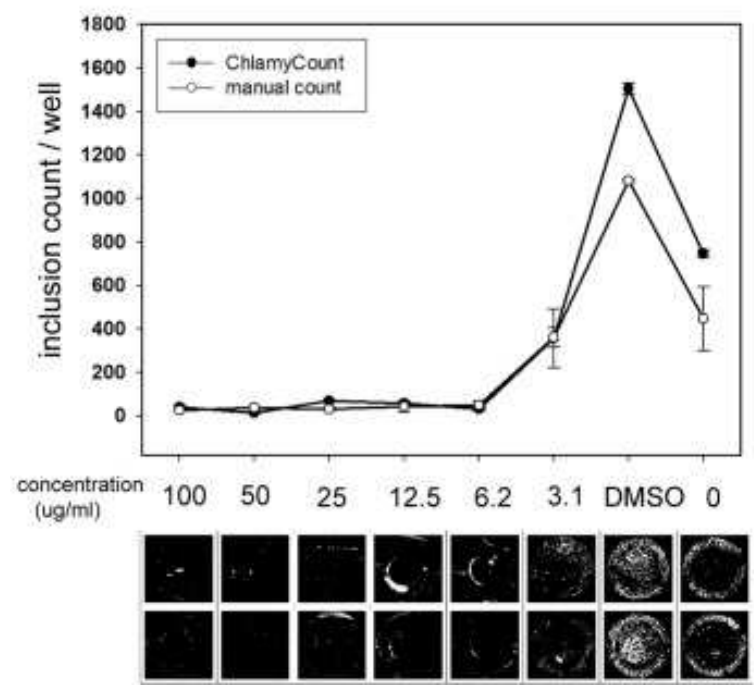

B

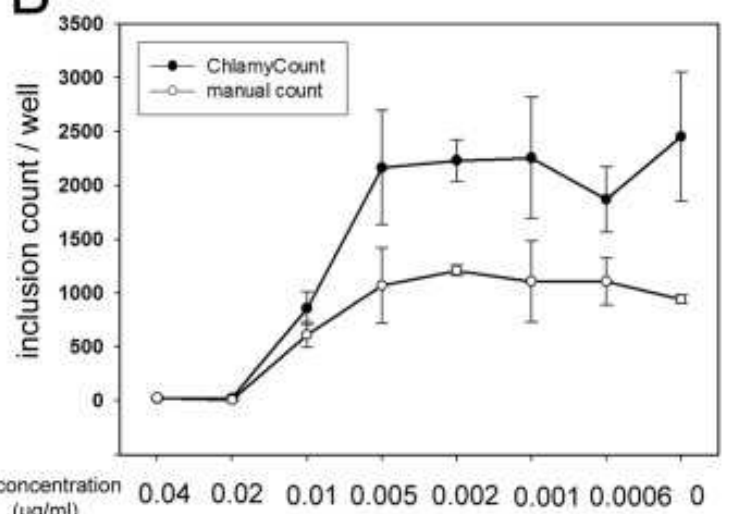

(ug/ml)
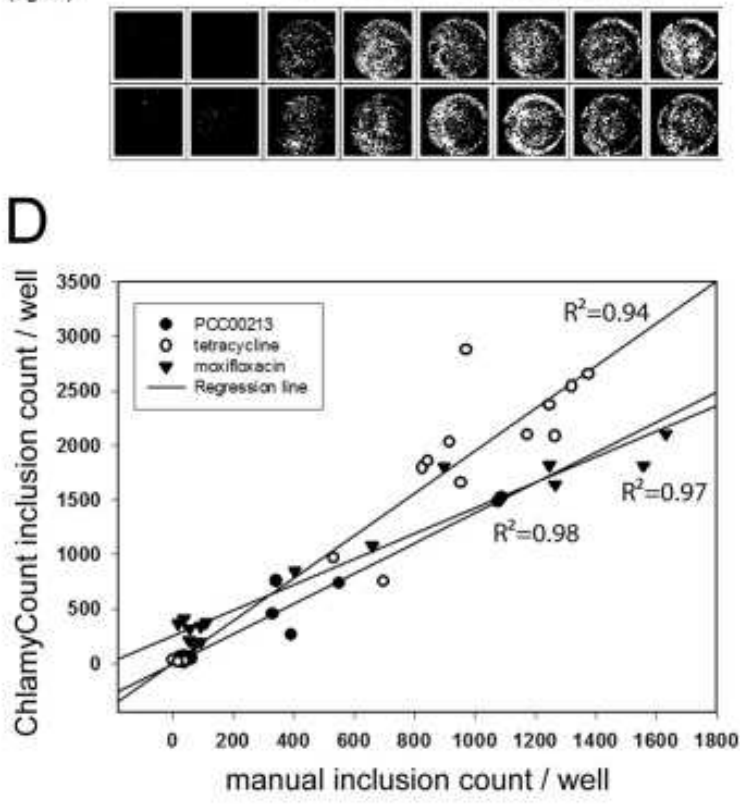

Figure 7. Estimation of MICs of known and novel antimicrobial compounds. McCoy cells were infected with $C$. trachomatis serovar D (MOI 1) in the presence of various concentrations of moxifloxacin (A), tetracycline (B), and PCC00213 (C). Each infection with a particular antibiotic concentration was performed using parallel wells. The inclusion counts were enumerated by ChlamyCount and manual confocal microscopy on the same slide. The scanned and ChlamyCountprocessed well images and the numerical data are shown. Data are means \pm standard deviations for the parallel wells. (D) Correlation between the inclusion numbers enumerated by the ChlamyCount method and manual counting. Each data point represents the inclusion number detected in a single well of the 16-well chamber slide. 


\subsection{Assessment of the effect of IFN- $\gamma$ on $C$. trachomatis serovar D and DEAE- dextran and cycloheximide on $C$. trachomatis serovar D and C. pneumoniae growth}

The inhibitory activity of IFN- $\gamma$ on chlamydial growth in human host cells via the degradation of the host tryptophan pool is a well-known phenomenon [87]. Byrne et al. [87] found that IFN- $\gamma$ had concentration-dependent inhibitory activity on $C$. psittaci growth in the human uroepithelial cell line T24, resulting in an approximately 10-fold reduction of direct inclusion counts at a $20-\mathrm{ng} / \mathrm{ml}$ IFN- $\gamma$ concentration. We performed $C$. trachomatis infection (MOI, 1) of McCoy murine fibroblastoid cells in the presence of murine and human IFN- $\gamma$. Despite the fact that the host species, cell line, and chlamydial species were different from those used by Byrne et al. [87], our experiments showed a comparable extent of inhibition, albeit at a lower murine IFN- $\gamma$ concentration: inhibition of chlamydial propagation was concentration dependent, and the maximum inhibition was approximately 3.8-fold at a murine IFN- $\gamma$ concentration of $1.5 \mathrm{IU} / \mathrm{ml}$ (approximately $0.07 \mathrm{ng} / \mathrm{ml}$ ) or higher (Figure 8. A, B) The human IFN- $\gamma$ control did not show any inhibitory effect even at a concentration of $100 \mathrm{IU} / \mathrm{ml}$ (Figure 8. A). It was an early observation that the pretreatment of host cells with DEAEdextran or treatment with cycloheximide could increase the number of chlamydial inclusions and the recoverable number of IFU [72],[88-90]. We applied ChlamyCount to detect these effects during C. trachomatis serovar D and C. pneumoniae infection. We pretreated HeLa cells with DEAE-dextran (1\% DEAE-dextran, $15 \mathrm{~min}, \mathrm{RT}$ ) and/or applied $1 \mu \mathrm{g} / \mathrm{ml}$ cycloheximide during the infection and compared the direct inclusion counts to those for the untreated cells. Our results showed partially different effects of these drugs on the growth of the two Chlamydia species (Figure 8. C,D). For C. trachomatis serovar D, the application of DEAE dextran showed only a marginal effect, but the cycloheximide treatment increased the direct inclusion count 1.9- to 2.2-fold largely independently of the presence of DEAE-dextran. For $C$. pneumoniae, the application of dextran or cycloheximide alone increased the direct inclusion count 2.4- and 3.3-fold, respectively, but the coaddition of the two drugs did not show a further growth-promoting effect. 
A

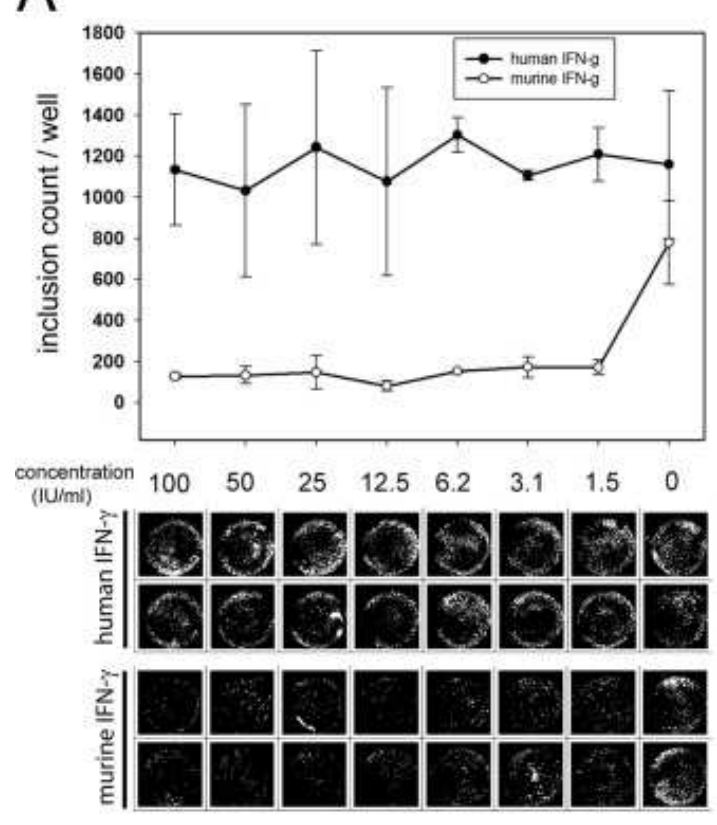

C

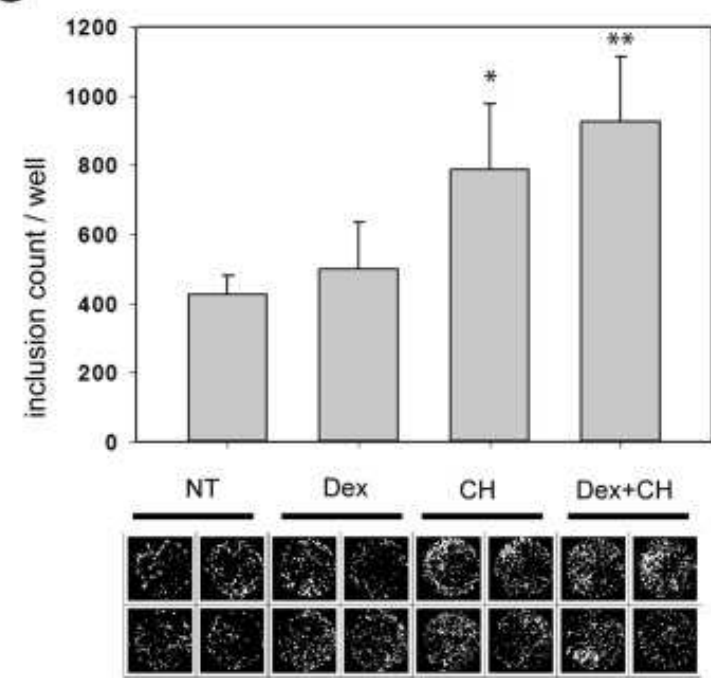

B

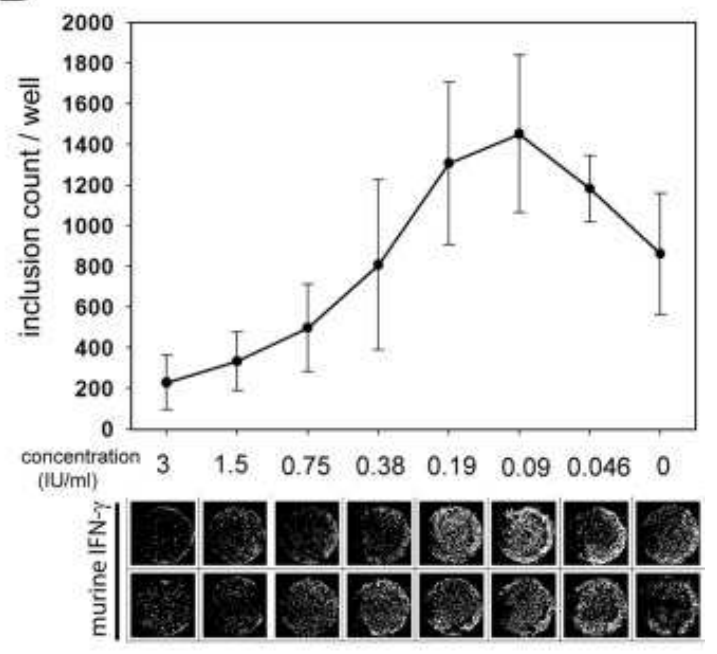

D

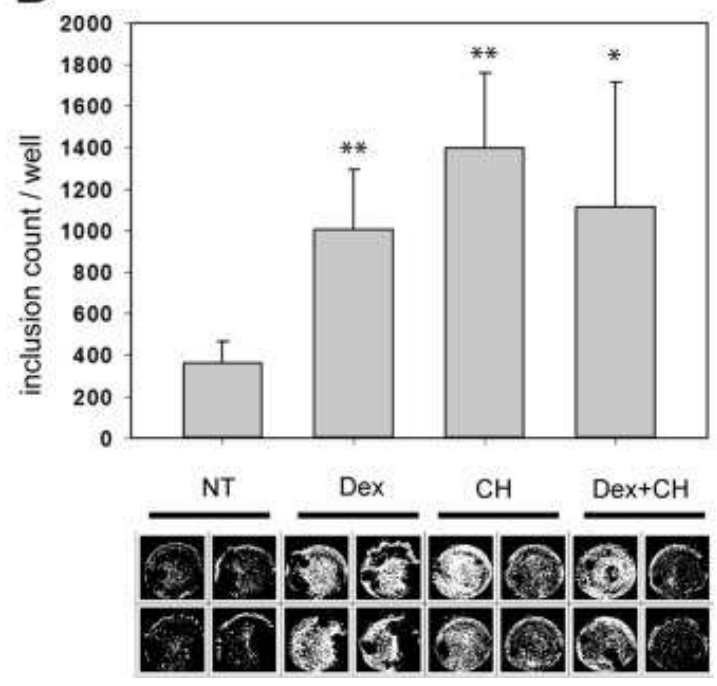

Figure 8. Measuring the effects of IFN- $\gamma$, DEAE-dextran, and cycloheximide on the direct inclusion counts of $C$. trachomatis serovar D and $C$. pneumoniae. McCoy cells were infected with $C$. trachomatis serovar D (MOI 1) in the presence of various concentrations of human (A) and murine (A, B) IFN- $\gamma$. HeLa cells were infected with $C$. trachomatis serovar D (MOI 0.5) (C) and C. pneumoniae (MOI, 1) (D) after pretreatment with 1\% DEAE-dextran (15 min, RT), and/or $1 \mu \mathrm{g} / \mathrm{ml}$ cycloheximide was applied during the infection. Each infection with a particular compound concentration was performed in two parallel wells. The scanned and ChlamyCount-processed well images and the numerical data are shown. Data are means \pm standard deviations for the parallel wells. Student's $t$ test was applied for statistical comparison of the treated versus the nontreated samples. $*, P<0.05$; **, $P<$ 0.01. NT, nontreated; Dex, DEAE-dextran treated; $\mathrm{CH}$, cycloheximide treated. The results of a representative experiment are shown. 


\subsection{Morphological and surface charge properties of the $\mathrm{TiO}_{2^{-}}$, $\mathrm{Ag}$ - and $\mathrm{TiO}_{2^{-}}$} Ag NPs

According to the TEM images the average particle size of the initial $\mathrm{TiO}_{2}$ NPs was $18.4 \pm$ $5.65 \mathrm{~nm}$ (Figure 9. A,D). The nominal content of anatase and rutile phases in the commercially available Aeroxide® $\mathrm{P} 25 \mathrm{TiO}_{2}$ powder was 80:20. The citrate stabilized Ag NPs obtained were nearly globular in shape (Figure 9. B), and their average particle size was $8.2 \pm 3.34 \mathrm{~nm}$ (Figure 9. E). In the case of $\mathrm{TiO}_{2}-\mathrm{Ag} \mathrm{NPs}$, the globular-shaped $\mathrm{Ag} \mathrm{NPs}$ accumulated on the surface on the $\mathrm{TiO}_{2}$ NPs were clearly seen (Figure 9. C), the average particle size was $21.4 \pm 6.78 \mathrm{~nm}$ (Figure 9. F).

Our data show, that the sizes of the NPs tested fell into the nanometer range with a high specific surface area.

A

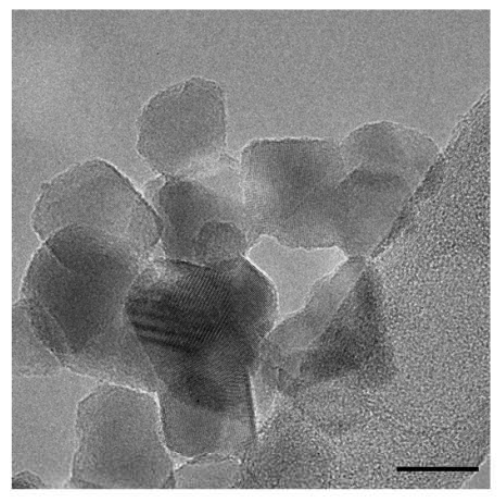

D

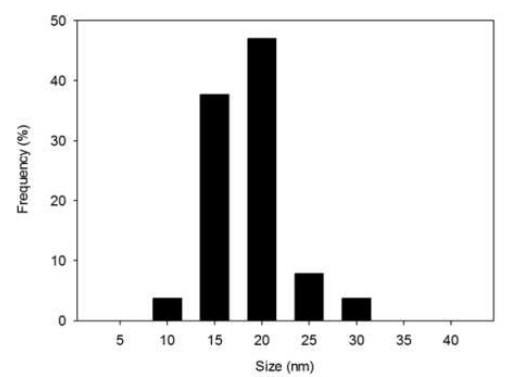

B

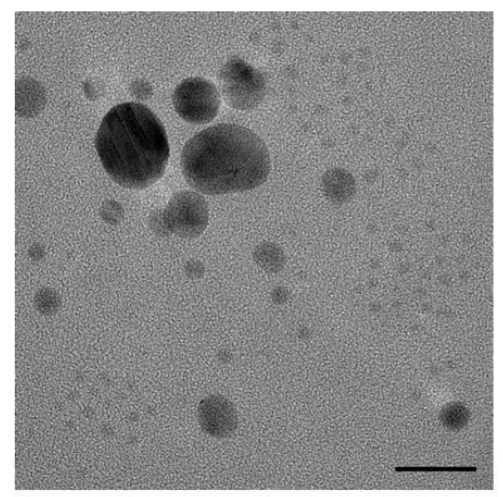

$E$

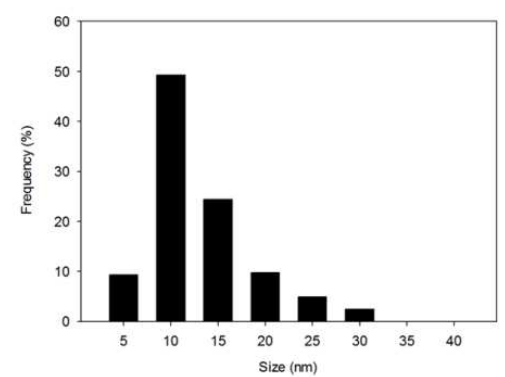

C

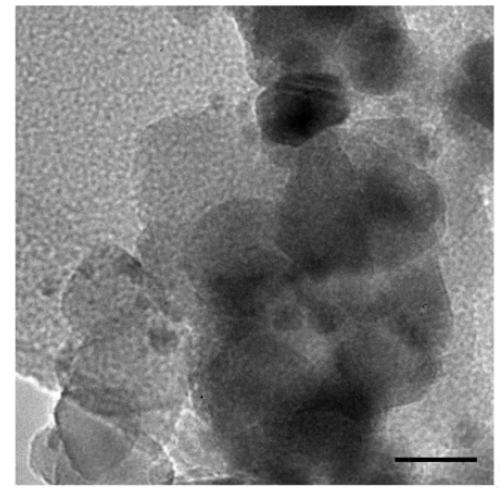

$\mathrm{F}$

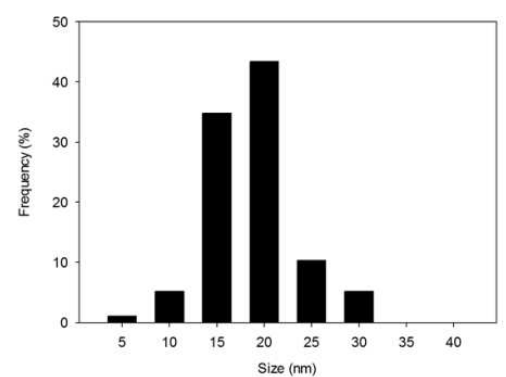

Figure 9. TEM images and size distribution measurements of the NPs. TEM images of the initial Degussa $\mathrm{P} 25 \mathrm{TiO}_{2}$ NPs (A), Ag NPs (B) and $\mathrm{TiO}_{2}-\mathrm{Ag}$ NPs (C). Bar: $20 \mathrm{~nm}$. Particle size distributions of Degussa P25 $\mathrm{TiO}_{2}$ NPs (D), Ag NPs (E) and $\mathrm{TiO}_{2}-\mathrm{Ag}$ NPs $(\mathbf{F})$.

The surface charge of the NPs tested was calculated from the streaming potential data in each case. Figure 10. shows plots of the charge titration curves, i.e. the measured 
streaming potential of $10 \mathrm{ml} 100 \mu \mathrm{g} / \mathrm{ml}$ nanoparticle suspensions titrated with $0.01 \% \mathrm{HDPCl}$ surfactant solution at $\mathrm{pH}=7.4$ in SPG media. The streaming potential values induced in the aqueous suspensions were negative at this $\mathrm{pH}$. It is well known from the literature that the $\mathrm{TiO} 2$ has a pH-dependent surface charge with a point of zero charge (p.z.c.) value of 6.2 [91]. Above this $\mathrm{pH}$ value, the surface of $\mathrm{TiO}_{2}$ is negatively charged. Accordingly, the initial -250 $\mathrm{mV}$ surface charge of the $\mathrm{TiO}_{2}-\mathrm{Ag}$ was continuously increased during the titration process due to the concomitant loss of surface charge. Considering the added amount of the charge compensating surfactant molecules $\left(\mathrm{n}_{\mathrm{HDPCl}}=3.55 \times 10-5 \mathrm{mmol}\right)$ and the mass of the measured $\mathrm{TiO}_{2}-\mathrm{Ag}\left(\mathrm{m}_{\mathrm{TiO}-\mathrm{Ag}}=1 \mathrm{mg}\right)$, the specific surface charge of $\mathrm{TiO}_{2}-\mathrm{Ag}$ NPs was $-3.54 \mathrm{meq} / 100 \mathrm{~g}$ at $\mathrm{pH}=7.4$ [specific charge $=\mathrm{c}_{\mathrm{HDPCl}} \cdot \mathrm{V}_{\mathrm{HDPCl}} / \mathrm{mTiO}_{2}$ ]. Similar to $\mathrm{TiO}_{2}-\mathrm{Ag} \mathrm{NPs}$, the initial P25 $\mathrm{TiO}_{2}$ - and Ag NPs were also titrated and -19.3 and -184.35 meq/100 g values were obtained, respectively. The results clearly showed, that the Ag NPs had the highest surface charge value, while the surface charge of $\mathrm{TiO}_{2}-\mathrm{Ag}$ NPs and $\mathrm{TiO}_{2} \mathrm{NPs}$ were negligible. The measurements also showed that the initial surface charge of the $\mathrm{TiO}_{2} \mathrm{NPs}(-19.3 \mathrm{meq} / 100 \mathrm{~g})$ were partially compensated by the Ag NPs with high surface charge $(-184.35 \mathrm{meq} / 100 \mathrm{~g})$. This is due to the surface accumulation of $\mathrm{Ag}$ NPs on the surface of $\mathrm{TiO}_{2}$ NPs in the case of $\mathrm{TiO}_{2}-\mathrm{Ag}$ NPs. This observation is in good agreement with the previously presented TEM images.

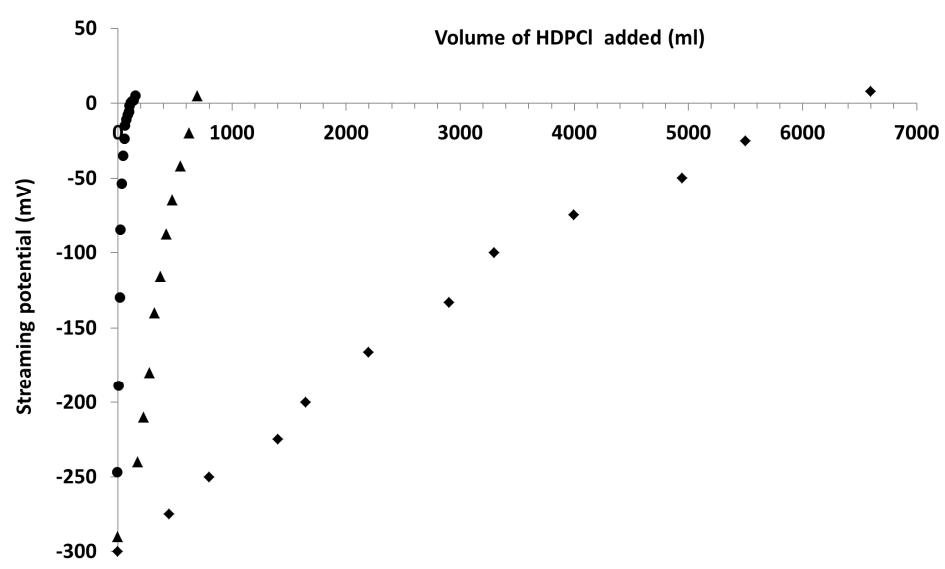

Figure 10. Charge titration curves of $10 \mathrm{ml} 100 \mu \mathrm{g} / \mathrm{ml}$ aqueous $\mathrm{TiO}_{2^{-}}, \mathrm{TiO}_{2}-\mathrm{Ag}$ - and $\mathrm{Ag} \mathrm{NPs}$ suspension with $0.01 \% \mathrm{HDPCl}$ surfactant solution. All three nanoparticles showed a negative surface charge at $\mathrm{pH}=7.4$ and it was compensated with $\mathrm{HDPCl}$ as opposite charged surfactants with concomitant streaming potential measurements. The calculated surface NP charge values (in meq/100 $\mathrm{g}$ unit) can be found in the text. 


\subsection{Cytotoxicity of the $\mathrm{TiO}_{2^{-}}, \mathrm{Ag}$ - and $\mathrm{TiO}_{2^{-}} \mathrm{Ag} \mathrm{NPs}$}

MTT assay was used to assess the cytotoxicity of the NPs applied (Fig. 3 A-B). HeLa cells were incubated for 48 hours with a 1:2 dilution series of the NPs or were left untreated as controls. We found that $\mathrm{TiO}_{2}-$ and $\mathrm{TiO}_{2}-\mathrm{Ag}$ NPs did not produce significant toxicity in the applied concentration range. Maximum cytotoxicity was observed at concentrations of 8-2 $\mu \mathrm{g}$ $\mathrm{ml}^{-1}$ for Ag NPs, the viability reached its maximum at $0.5 \mu \mathrm{g} \mathrm{ml}^{-1}$. We considered $0.5 \mu \mathrm{g} \mathrm{ml}^{-1}$ as the maximum non-toxic concentration for Ag NPs. The maximum non-toxic concentration of $\mathrm{TiO}_{2}$ - and $\mathrm{TiO}_{2}-\mathrm{Ag}$ NPs was $100 \mu \mathrm{g} \mathrm{ml}^{-1}$. Vero cells showed similar toxicity profiles. $\mathrm{TiO}_{2}-$ and $\mathrm{TiO}_{2}-\mathrm{Ag}$ NPs were not toxic at the concentrations applied. $0.5 \mu \mathrm{g} \mathrm{ml}^{-1} \mathrm{Ag}$ NPs treatment resulted a $\sim 70 \%$ viability, and $0.125 \mu \mathrm{g} \mathrm{ml}^{-1}$ was the maximum non-toxic concentration for Ag NPs. To be able to compare the two cell lines, the subsequent growth inhibitory experiments were started with $100 \mu \mathrm{g} \mathrm{ml}^{-1} \mathrm{TiO}_{2}$ - and $\mathrm{TiO}_{2}$-Ag NPs, and $0.5 \mu \mathrm{g} \mathrm{ml}^{-1} \mathrm{Ag} \mathrm{NPs}$.

A

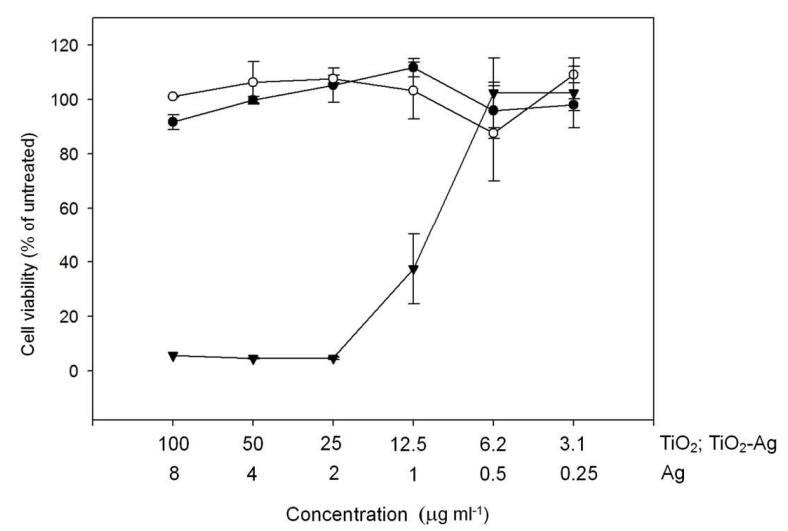

B

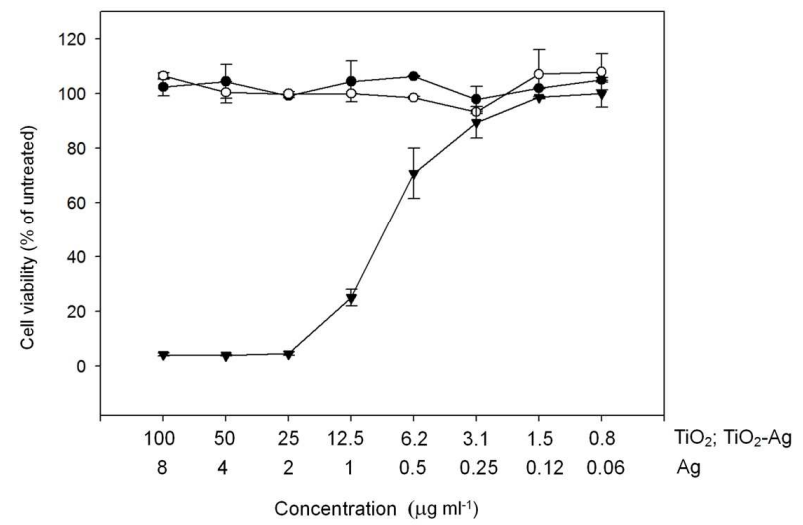

Figure 11. MTT cell viability assay of the NP-treated HeLa and Vero cells. HeLa (A) and Vero (B) cells were treated with a 1:2 dilution series of $\mathrm{TiO}_{2^{-}}, \mathrm{Ag}$ - and $\mathrm{TiO}_{2}-\mathrm{Ag}$ NPs for $48 \mathrm{~h}$. MTT assay was performed as described in the Materials and Methods. Three parallel measurements were performed for each NP concentration. Data are means $+/$ - standard deviation $(n=3)$.

\subsection{Assessment of the impact of the $\mathrm{TiO}_{2^{-}}$, $\mathrm{Ag}$ - and $\mathrm{TiO}_{2}-\mathrm{Ag} \mathrm{NPs}$ on $C$. trachomatis and HSV-2 growth by direct qPCR}

We used direct qPCR method [79] to determine the antimicrobial activity of the NPs on C. trachomatis (Figure 12. A) and HHSV-2 (Figure 12. B). HeLa or Vero cells were infected with $C$. trachomatis (MOI 8) or HHSV-2 (MOI 0.1) after preincubation $\left(1 \mathrm{~h}, 37{ }^{\circ} \mathrm{C}\right.$ ) with serial 1:4 dilutions of the NPs, starting with the concentrations of $100 \mu \mathrm{g} / \mathrm{ml}$ for $\mathrm{TiO}_{2}-$ 
and $\mathrm{TiO}_{2}-\mathrm{Ag} \mathrm{NPs}$, and $0.5 \mu \mathrm{g} / \mathrm{ml}$ for Ag NPs. It should be noted, that the Ag content of the $\mathrm{TiO}_{2}-\mathrm{Ag}$ NPs was the same as that of the Ag NPs in all of the concentrations applied. Also, it should be mentioned, that in order to mimic the in vivo circumstances we did not use centrifugation for the chlamydial and HHSV-2 infections. QPCR measurement of the control, nanoparticle-free $C$. trachomatis growth resulted in a $\mathrm{Ct}$ value of $26.81+/$ - 0.58 . Interestingly, the $\mathrm{TiO}_{2}$ NPs increased the growth of $C$. trachomatis relative to the control. The growth stimulation was concentration- dependent, with a $\mathrm{Ct}$ value of $24.85+/-0.64$ at the maximum $\mathrm{TiO}_{2}$ NP concentration. The difference of 1.96 qPCR cycles $(\Delta \mathrm{Ct}=26.81-24.85)$ DNA concentration between the $\mathrm{TiO}_{2} \mathrm{NP}$ - treated and the control C. trachomatis means $\sim 3.89$ fold $\left(\sim 2^{1.96}\right)$ growth increase.

A

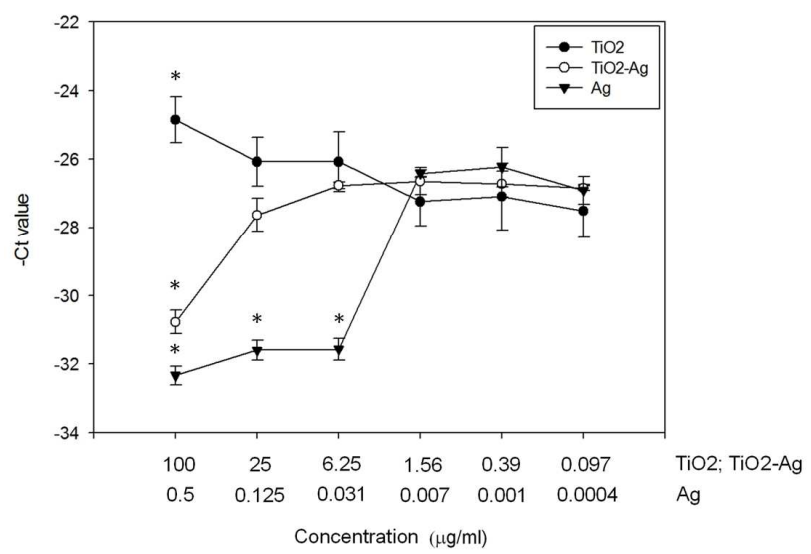

B

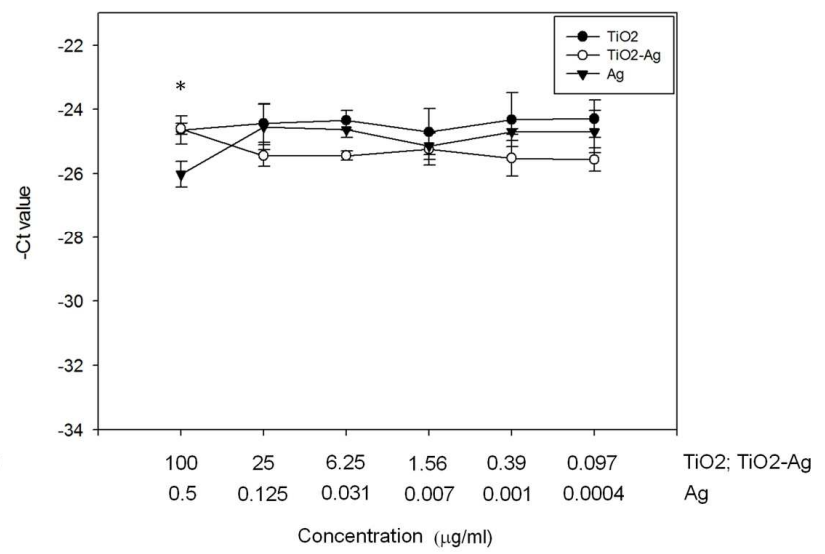

Figure 12. Measurement of the antimicrobial activity of the $\mathrm{TiO}_{2}-$, $\mathrm{Ag}$ - and $\mathrm{TiO}_{2}-\mathrm{Ag} \mathrm{NPs}$ by direct qPCR. HeLa cells were infected with $C$. trachomatis (MOI 8) preincubated with a 1:4 dilution series of $\mathrm{TiO}_{2-}$, $\mathrm{Ag}$ - and $\mathrm{TiO}_{2}-\mathrm{Ag}$ NPs for $1 \mathrm{~h} 37^{\circ} \mathrm{C}$ (A). Vero cells were infected with HHSV-2 (MOI 0.1) preincubated with a 1:4 dilution series of $\mathrm{TiO}_{2^{-}}, \mathrm{Ag}$ - and $\mathrm{TiO}_{2}-\mathrm{Ag} \mathrm{NPs}$ for $1 \mathrm{~h} 37^{\circ} \mathrm{C}(\mathbf{B})$. Each infection at a particular NP concentration was performed in three parallel wells. At $48 \mathrm{~h}$ post infection (C. trachomatis) and $12 \mathrm{~h}$ post infection (HHSV-2), the cells were lysed and the DNA concentrations of the pathogens were measured by pathogen specific direct qPCRs. Data are the average $-\mathrm{Ct}$ values $+/$ - standard deviation $(n=3)$. Student's t-test were used to compare the $\mathrm{Ct}$ value between the treated and untreated infected cells $(*: \mathrm{p}<0.05)$.

Ag NPs had a strong inhibitory activity against $C$. trachomatis between the 0.5-0.031 $\mu \mathrm{g} / \mathrm{ml}$ concentrations. On the other hand, $\mathrm{TiO}_{2}-\mathrm{Ag}$ NPs showed reduced antimicrobial activity compared to the Ag NPs against $C$. trachomatis, despite the fact that the Ag content of the $\mathrm{TiO}_{2}$-Ag NPs was the same as the Ag NPs'. The difference in antichlamydial activity was the 
most pronounced at the $25 \mu \mathrm{g} / \mathrm{ml}$ and $6.25 \mu \mathrm{g} / \mathrm{ml} \mathrm{TiO}_{2}-\mathrm{Ag}$ NP concentrations, where the growth difference between the Ag NP and TiO2-Ag NP treated Chlamydiae was 15.59 and 27.92 fold respectively (3.96 and 4.8 qPCR cycles difference, respectively).

\subsection{Estimation of the time dependence of the $\mathrm{TiO}_{2}$ growth enhancing effect on C. trachomatis}

To identify the exact time window when the $\mathrm{TiO}_{2}$ NPs alter $C$. trachomatis growth, we performed an experiment where $i$, the $\mathrm{TiO}_{2}$ NPs were preincubated with the $C$. trachomatis elementary bodies one hour before infection and coincubated during the infection for an additional hour $i$, the $\mathrm{TiO}_{2}$ NPs were coincubated with the $C$. trachomatis elementary bodies during the one-hour-long infection $\mathrm{iii}$, the $\mathrm{TiO}_{2} \mathrm{NPs}$ were added to the C. trachomatis infected HeLa cells at various time points (0-32 hours) post infection (Figure 13. A). In order to compare the effects of $\mathrm{TiO}_{2} \mathrm{NPs}$ at various time points, the $\mathrm{TiO}_{2} \mathrm{NPs}$ were applied for the same duration (1h) at each time point and after they were washed away. No centrifugation was used for the infection. Data showed that the growth enhancing effect of $\mathrm{TiO}_{2} \mathrm{NPs}$ was detected at the coincubation + infection treatment ( $\sim 2$ qPCR cycles, 4 fold growth increase), and when the $\mathrm{TiO}_{2}$ was applied during the one hour infection ( 2 qPCR cycles, 4 fold growth increase). It is worth to note, that a second, minor growth increase was detected at 10 hours post infection. The TEM images showed, that both HeLa and Vero cells incorporated the $\mathrm{TiO}_{2}$

NPs (Figure 13. B-C), therefore the lack of HHSV-2 growth increasing effect in Vero cells is not due to the cells' inability of $\mathrm{TiO}_{2} \mathrm{NP}$ uptake.

A

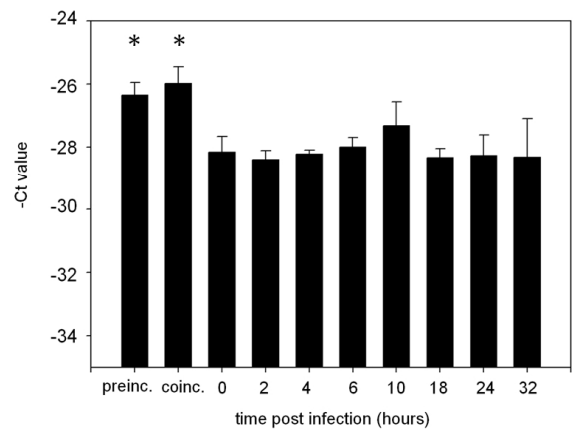

B

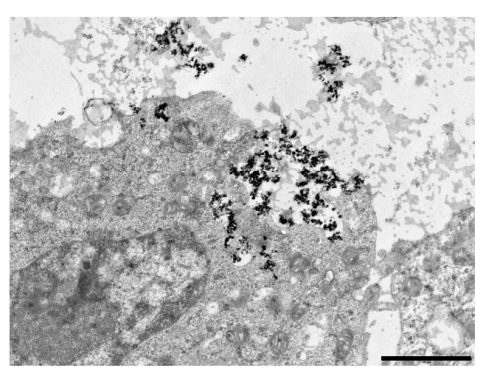

C

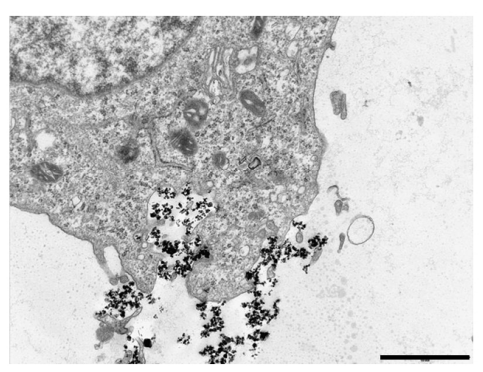

Figure 13. Measurement of the kinetics of the TiO2 NP-mediated $C$. trachomatis growth enhancement and visualization of the $\mathrm{TiO} 2 \mathrm{NP}$ uptake. $\mathrm{TiO}_{2} \mathrm{NPs}(100 \mu \mathrm{g} / \mathrm{ml})$ were applied at different timepoints 
post infection. At $48 \mathrm{~h}$ post infection, the infected HeLa cells were lysed and the chlamydial DNA concentration was measured by qPCR $(n=3)$. (preinc.: $\mathrm{TiO}_{2} \quad \mathrm{NPs}$ were preincubated with the $C$. trachomatis elementary bodies $\left(1 \mathrm{~h}, 37^{\circ} \mathrm{C}\right)$ and $\mathrm{TiO}_{2} \mathrm{NPs}$ were also present during the infection process $\left(1 \mathrm{~h}, 37^{\circ} \mathrm{C}\right)$; coinc.: $\mathrm{TiO}_{2} \mathrm{NPs}$ were present only during the infection process $\left(1 \mathrm{~h}, 37^{\circ} \mathrm{C}\right)$. Data are the average $-\mathrm{Ct}$ values $+/$ - standard deviation $(\mathrm{n}=3)$. TEM images of the uptake $\left(1 \mathrm{~h}\right.$ post treatment, $\left.37^{\circ} \mathrm{C}\right)$ of $\mathrm{TiO}_{2} \mathrm{NPs}$ by HeLa (B) and Vero cells $(\mathbf{C})$. Bar is $10 \mu \mathrm{m}$. Student's t-test were used to compare the $\mathrm{Ct}$ value between the $\mathrm{TiO}_{2}$-NP-treated and untreated infected cells $(*: \mathrm{p}<0.05)$.

\subsection{Estimation of the direct impact of the $\mathrm{TiO}_{2}-$, $\mathrm{Ag}$ - and $\mathrm{TiO}_{2}-\mathrm{Ag} \mathrm{NPs}$ on the qPCR}

Since the growth-related chlamydial DNA concentrations were measured by a direct qPCR method, we wanted to test the potential impact of the NPs on the DNA polymerase of the qPCR (Figure 14.). A qPCR enzyme inhibitory effect would appear as a false antichlamydial activity, while a stimulatory effect would appear as a false chlamydial growth enhancing effect. Cell lysates of HeLa cells infected with untreated C. trachomatis were mixed with cell lysates from uninfected cells treated with twice the maximum concentration of NPs used in the qPCR experiments, so that the final concentration of the NPs in this mixture would be the maximal concentration applied in the growth inhibition experiments. As controls, uninfected and untreated cell lysates were also mixed with $C$. trachomatis-infected cell lysates. If there was no direct impact of NPs on the qPCR, then the Ct levels of the mixture of the infected and uninfected but NP containing cell lysates would have been similar to the above-mentioned controls. The $\mathrm{Ct}$ levels of the $C$. trachomatis $+\mathrm{TiO}_{2} \mathrm{NP}, C$. trachomatis $+\mathrm{TiO}_{2}-\mathrm{Ag} \mathrm{NP}$ and C. trachomatis $+\mathrm{Ag}$ NP mixtures were only 0.64, 0.73 and 0.11 cycles lower, respectively than the control's. Similar experiments were performed to test the impact of NPs on the HHSV-2 qPCR. The Ct levels of the HHSV-2 + $\mathrm{TiO}_{2} \mathrm{NP}, \mathrm{HHSV}-2$ $+\mathrm{TiO}_{2}-\mathrm{Ag} \mathrm{NP}$ and HHSV-2 + Ag NP mixtures were only $0.14,0.143$ and 0.34 cycles lower respectively than the control's. These results supported the presumption that the observed increase or decrease of $C$. trachomatis and HHSV-2 growth could not be due to the stimulation or inhibition of the qPCR itself. 


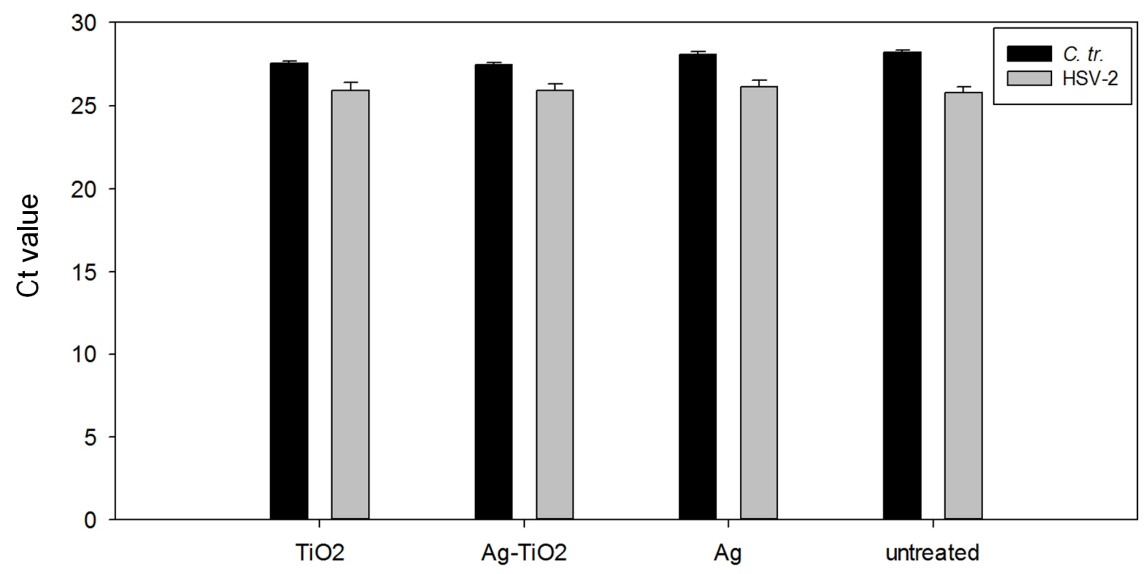

Figure 14. Estimation of the direct impact of TiO2-, Ag- and TiO2-Ag NPs on the qPCR. Cell lysates of HeLa cells infected with untreated $C$. trachomatis (MOI 8, 48h post infection) mixed with cell lysates from uninfected HeLa cells treated with $200 \mu \mathrm{g} / \mathrm{ml} \mathrm{TiO}_{2} \mathrm{NPs}, 200 \mu \mathrm{g} / \mathrm{ml} \mathrm{TiO}_{2}-\mathrm{Ag}$ NPs and 1 $\mu \mathrm{g} / \mathrm{ml} \mathrm{Ag} \mathrm{NPs,} \mathrm{respectively} \mathrm{(} \mathrm{n}=3)$. Ct values were compared to the untreated $C$. trachomatis infected cells $(n=3)$. Cell lysates of Vero cells infected with untreated HHSV-2 (MOI 0.1, 24h post infection) mixed with cell lysates from uninfected Vero cells treated with $200 \mu \mathrm{g} / \mathrm{ml} \mathrm{TiO}_{2} \mathrm{NPs}, 200 \mu \mathrm{g} / \mathrm{ml} \mathrm{TiO}_{2^{-}}$ $\mathrm{Ag}$ NPs and $1 \mu \mathrm{g} / \mathrm{ml}$ Ag NPs respectively $(\mathrm{n}=3)$. Ct values were compared to the untreated HHSV-2 infected cells $(n=3)$. Data are the average $\mathrm{Ct}$ values $+/$ - standard deviation $(\mathrm{n}=3)$.

\subsection{Quantitative immunofluorescent measurement of the impact of $\mathrm{TiO}_{2} \mathrm{NPs}$}

\section{on C. trachomatis growth}

An independent immunofluorescent growth measurement method was used [42] to validate the qPCR results (Figure 15.). HeLa cells cultured on a 16-well chamber slide were infected with C. trachomatis (MOI 8) after preincubation at various concentrations of $\mathrm{TiO}_{2} \mathrm{NPs}$. No centrifugation was used for the infection. Infected but untreated and uninfected $+\mathrm{TiO}_{2} \mathrm{NP}-$ treated cells $(100 \mu \mathrm{g} / \mathrm{ml})$ were also included as controls. Cells were fixed at $48 \mathrm{~h}$ post infection, and the chlamydial inclusions were labeled with an Alexa-647-labelled antichlamydia LPS antibody. As described previously [42], the slide was scanned with a DNAchip scanner, and the ChlamyCount software was used to enumerate the chlamydial inclusions. ChlamyCount inclusion number counts supported the qPCR results. 


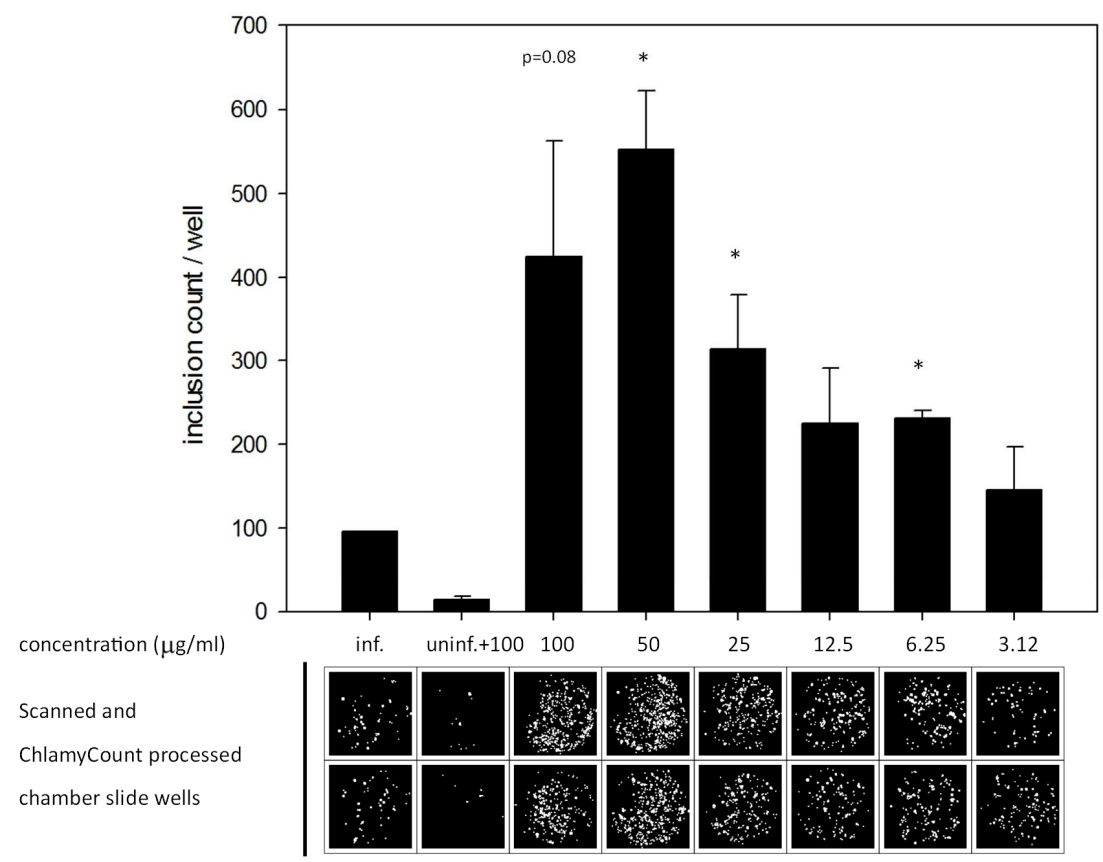

Figure 15. Measurement of the impact of $\mathrm{TiO}_{2}$ NPs on C. trachomatis growth. HeLa cells were infected with $C$. trachomatis (MOI 8) in the presence of a concentration range of $\mathrm{TiO}_{2} \mathrm{NPs}_{\text {. Untreated }}$ C. trachomatis infected wells and uninfected $\mathrm{TiO}_{2}-\mathrm{NP}$-treated wells were included as controls. Each infection was performed using parallel wells. The chlamydial inclusions were enumerated by the ChlamyCount software 48 hours post infection. The ChlamyCount processed well images and the inclusion numbers counted are shown. Data are means $+/$ - standard deviation $(n=2)$. Student's t-test were used to compare the inclusion counts between $\mathrm{TiO}_{2}$-NP-treated and untreated infected cells $(*$ : $\mathrm{p}<0.05)$.

$\mathrm{TiO}_{2}$ NP pretreatment of the chlamydial elementary bodies induced an increase in chlamydial inclusion numbers, with a 400\%-500\% increase at the 100 and $50 \mu \mathrm{g} / \mathrm{ml} \mathrm{TiO}_{2} \mathrm{NPs}$ concentrations, and a gradual, concentration-dependent decrease in growth enhancement in the 25-3.12 $\mu \mathrm{g} / \mathrm{ml} \mathrm{TiO}_{2}$ NPs concentration range. Uninfected but $\mathrm{TiO}_{2} \mathrm{NP}$ treated wells displayed only marginal positivity, indicating that the observed increase of chlamydial immunofluorescence was not due to the aspecific binding of the anti-chlamydial LPS antibody to $\mathrm{TiO}_{2} \mathrm{NPs}$. 


\section{Discussion}

\subsection{Aim 1: To develop an automatic system for counting the chlamydial inclusions: ChlamyCount Software}

We designed a low-cost, medium-throughput method for the rapid enumeration of chlamydial inclusions. Chlamydial inclusions on a 16-well chamber slide were labeled by a fluorescently labeled genus-specific antibody and scanned by a commercial DNA chip scanner. In this detection system, the DNA chip scanner is the most expensive component; however, these scanners are easily available in core facilities, and in many cases, the newgeneration sequencing technology makes these scanners infrequently used or redundant. Our technology reuses these scanners in a novel role, when the high-resolution images produced by these scanners are used to visualize chlamydial inclusions. The images are processed either completely automatically or after small intensity and area threshold adjustments on a single desktop computer with an average or low-average year 2013 hardware configuration (Intel Core2 $6600 \mathrm{CPU}$ at $2.4 \mathrm{GHz}, 2$ GB RAM, ATI Radeon HD 3600 series video card).

The "gold standard" test of inclusion counting is the infection of host cells with serial dilutions of Chlamydia and the subsequent counting of inclusions. Our method was capable of counting 1:2 dilutions of inclusions of three different chlamydial species and provided a high correlation with the theoretical estimates. The system was capable of measuring the inclusion counts over a 1-log-unit range, which is comparable to or better than that of other previously described methods [80,92-94]. As with the other methods, a limitation of the ChlamyCount method at higher MOIs is the accurate dissection of the high number of confluent or nearly confluent fluorescent areas that originate from close inclusions. Also, ChlamyCount detects a higher number of inclusions than manual counting by microscopy, likely because the software detects smaller fluorescent areas as inclusions. Therefore, the current version of ChlamyCount may not be used for the absolute quantitation of inclusions. ChlamyCount was designed to measure the effect of various treatments on chlamydial growth, and for this task, it is enough to follow the changes in inclusion counts with a high degree of accuracy and it is not necessary to determine their absolute number.

Indeed, we could demonstrate that the inclusion counts detected by ChlamyCount and manual microscopy closely correlated and therefore could be applied to tasks where the 
detection of changes in bacterial (inclusion) counts are important, such as MIC determination. We used ChlamyCount to determine the MICs of two well-characterized antichlamydial antibiotics with different mechanisms of action: the ribosome inhibitor tetracycline and the gyrase inhibitor moxifloxacin. In both cases, ChlamyCount was able to determine that the MIC values were identical to the MIC values determined by manual microscopy and also close to the previously described values. ChlamyCount was also able to reproducibly determine the MIC value of the novel antichlamydial compound PCC00213. Besides antibiotics, various chemicals and cytokines can affect chlamydial growth in a positive or a negative manner. ChlamyCount was also able to determine the previously described inhibitory effect of IFN- $\gamma$ and the growth-promoting effect of DEAE-dextran and cycloheximide. Importantly, these data show that ChlamyCount can be used to quantitatively measure the fold changes in inclusion counts between treated and control samples. This type of relative quantitation makes our method applicable in chlamydia basic biology experiments where the effect of a given treatment should be quantitatively measured.

Considering the previously described methods [95], the rapid estimation of chlamydial growth can be achieved via two approaches. The first approach uses either a fluorimeter or a spectrophotometer to measure the total intensity of a Chlamydia-specific fluorescently labeled antibody [96] or indirectly measure Chlamydia growth by measuring decreased host cell metabolism after Chlamydia- induced lysis [93]. These methods are rapid and inexpensive but do not rely on counting the individual inclusions; hence, the possibility of aspecific antibody binding or an aspecific change in host cell metabolism cannot be excluded. The second approach mostly $[80,94]$ but not exclusively [92] uses automatic microscopes to take a certain number of images per well, followed by computer image analysis for the specific detection and enumeration of inclusions. ChlamyCount relates to these methods. Compared to the recently described automatic microscope-based inclusion counting method [80], our method has certain advantages and disadvantages. The automatic microscope-based method uses 96well plates and obviously produces images with a higher resolution. Since analyzing the images requires significant computational power, the image analysis is performed by a computer cluster with 16 processors. In contrast, our method has a lower throughput, but the analysis time is significantly shorter; therefore, the processing time for 96 samples $(6 \times$ the 16 wells in the chambers) is comparable, at least for the first 96 samples. The ChlamyCount system set-up cost is generally lower, and the computational support required is significantly 
simpler. Although it has a lower resolution, ChlamyCount also preserves a major advantage of the automatic microscope-based methods; namely, it provides topological information about the inclusions. Since DNA chip scanners can scan at two different wavelengths, our method can potentially be applied to provide colocalization information, allowing, e.g., testing of the effect of anti- or prochlamydial proteins recombinantly expressed in the host cells.

\subsection{Aim 2: To investigate the impact of novel compounds and nanomaterials on the growth of $C$. trachomatis and HHSV-2}

As the usage of $\mathrm{TiO}_{2}$ NPs is significant and the prevalence of $C$. trachomatis and HHSV-2 is high, it is important to study their interactions. Therefore we performed an in vitro study where we evaluated the impact of non-activated $\mathrm{TiO}_{2} \mathrm{NPs}$ on the growth of $C$. trachomatis and HHSV-2. Since the activated $\mathrm{TiO}_{2}$ NPs have well described antimicrobial activity [97,98], we hypothesized, that the non-activated $\mathrm{TiO}_{2} \mathrm{NPs}$ would not have any effect on the growth of these two intracellular pathogens. Indeed, $\mathrm{TiO}_{2^{-}}$and $\mathrm{TiO}_{2}-\mathrm{Ag}$ NPs had no effect on HHSV-2 growth in the tested concentration range, and Ag NPs only displayed a minimal inhibition (about two-fold) at the highest concentration. It is worth to note, that the addition of $\mathrm{TiO}_{2}$ to $\mathrm{Ag}$ NPs eliminated completely this minimal HHSV-2 inhibitory activity. On the other hand, qPCR growth measurements showed that the $\mathrm{TiO}_{2}$ NPs significantly promoted the chlamydial growth at the $100 \mu \mathrm{g} / \mathrm{ml}$ concentration. Albeit not reached the significance threshold, the growth promoting effect could also be detected at the $50 \mu \mathrm{g} / \mathrm{ml}$ and $25 \mu \mathrm{g} / \mathrm{ml}$ concentrations. Since the growth promoting effect of $\mathrm{TiO}_{2} \mathrm{NPs}$ was unexpected, and chlamydial DNA synthesis can be observed in the absence of active growth (e.g in persistence), we applied an independent, immunofluorescence based method to validate the data. We applied the ChlamyCount system to quantitate chlamydial inclusions. ChlamyCount measurements supported the qPCR data with a prominent growth increasing effect at the 100 $\mu \mathrm{g} / \mathrm{ml}$ and $50 \mu \mathrm{g} / \mathrm{ml} \mathrm{TiO} 2$ NP concentration range. The observed $\mathrm{TiO}_{2}$ growth increase of $C$. trachomatis was unexpected, but not without precedent in the literature. A recent study by $\mathrm{Xu}$ et al. showed that non-activated $\mathrm{TiO}_{2} \mathrm{NPs}$ increased the attachment/ internalization of Staphylococcus aureus (S. aureus) to HeLa cells [99]. HeLa cells treated with $100 \mu \mathrm{g} / \mathrm{ml} \mathrm{TiO}_{2}$ NPs (the same concentration that increased the growth of $C$. trachomatis by about $400 \%$ in our study) for 24 hours resulted in a 250-350\% increase of $S$. aureus attachment/ 
internalization. In contrast to the chlamydial infection, $\mathrm{TiO}_{2} \mathrm{NPs}$ did not alter HHSV-2 growth, therefore the HHSV developmental cycle does not benefit from the cellular process(es) that was induced by $\mathrm{TiO}_{2} \mathrm{NPs}$, or the $\mathrm{TiO}_{2}$ NPs could not induce the growth promoting cellular effects in Vero cells. Our data support the latter: since $\mathrm{TiO}_{2} \mathrm{NPs}$ were not able to increase chlamydial growth in Vero cells (data not shown), the $\mathrm{TiO}_{2} \mathrm{NP}$-related growth promoting effect had a cell-type dependent component.

Chlamydia has a complex developmental cycle, starting with the attachment of the infectious form, the so-called elementary body to the plasma membrane of the target cells. After attachment, the elementary body enters the cell, and differentiates to the non-infectious, but replicating form, the reticulate body. Reticulate bodies grow in a membrane bound vacuole, the so-called inclusion in the cytoplasm of the host cell. The reticulate bodies then redifferentiate to elementary bodies and exit the host cells 48-72h post infection. Theoretically, this complex developmental cycle can be influenced by the $\mathrm{TiO}_{2} \mathrm{NPs}$ at various stages. Our kinetic experiments revealed that the $\mathrm{TiO}_{2}$ NPs promoted chlamydial growth when they were added to the elementary bodies before the infection or added during the infection. This result indicates that $\mathrm{TiO}_{2}$ NPs facilitated the attachment/ entry of the chlamydial elementary bodies to the host cells. Chlamydia enters into the target cell via multiple mechanisms including phagocytosis, caveolae-mediated endocytosis and clathrinmediated endocytosis. Among these processes, clathrin-mediated endocytosis seems to be important for $C$. trachomatis entry to epithelial cells [100]. $\mathrm{TiO}_{2} \mathrm{NPs}_{\text {san }}$ also enter via clathrin- mediated endocytosis [101], and thus there is a possibility that the $\mathrm{TiO}_{2} \mathrm{NP}$ entry costimulates the entry of the chlamydial elementary bodies. On the other hand, our TEM images showed $\mathrm{TiO}_{2} \mathrm{NP}$ incorporation after 1 hour post incubation in both HeLa and Vero cells, while the chlamydial growth promoting effect could not be detected in Vero cells (data not shown), therefore a mechanistic co-uptake is not likely the source of growth promotion. The net charge of the $C$. trachomatis elementary bodies are negative [102], and the infectivity of the $C$. trachomatis urogenital serovars (D-K) can be enhanced by polycations such as DEAEdextrane and poly-L lysine and can be inhibited by polyanions such as dextrane-sulphate [103]. The observed chlamydial growth-promoting effect cannot be explained by the $\mathrm{TiO}_{2}$ NP-mediated bridging of the negatively charged $C$. trachomatis elementary body and the negatively charged host cell plasma membrane, since the net charge of the $\mathrm{TiO}_{2} \mathrm{NPs}$ were close to zero. Altogether this data indicate that the $\mathrm{TiO}_{2}$ NPs binding/ incorporation itself is 
not a key factor in chlamydial growth promotion, rather the incorporated $\mathrm{TiO}_{2} \mathrm{NPs}$ may induce a unique early signal transduction or plasma membrane alteration in HeLa cells that are beneficial to chlamydial growth.

Silver-containing antimicrobials were commonly used before to treat $C$. trachomatis conjunctival infections and were shown to inhibit HHSV-2 replication [104,105]. Interestingly, while the pure $\mathrm{TiO}_{2} \mathrm{NPs}$ did not influence $\mathrm{HHSV}$ growth, the $\mathrm{TiO}_{2}-\mathrm{Ag} \mathrm{NPs}$ showed reduced antimicrobial activity against both $C$. trachomatis and HHSV-2 than the AgNPs. The reduction of antichlamydial activity in certain concentrations was close to 30 fold. It is possible that the antichlamydial effect of Ag NPs -at least partially- is due to their high negative charge. As we showed, the $\mathrm{TiO}_{2}-\mathrm{Ag}$ NPs have a more positive net charge compared to Ag NPs, which may contribute to the lower antichlamydial effect.

Our study is one of the few, where the impact of non-activated $\mathrm{TiO}_{2}$ NPs on the growth of intracellular pathogens has been measured. Because of the high prevalence and debilitating sequelae of $C$. trachomatis infections, the $\mathrm{TiO}_{2} \mathrm{NP}$ - induced growth promotion is a significant finding which requires further animal model/epidemiology investigations. An important application of NPs is the drug delivery of antimicrobials. It is generally accepted that the antichlamydial effect of the first-choice antibiotic azithromycin is augmented by its intracellular accumulation [106]. Theoretically, the uptake and intracellular accumulation of $\mathrm{TiO}_{2}$ NPs make them particularly amenable for use as antimicrobial compound delivery vehicle to combat intracellular pathogens. The fact that addition of $\mathrm{TiO}_{2}$ greatly reduced the antichlamydial activity and reduced the antiviral activity of Ag NPs highlights the need for further testing of $\mathrm{TiO}_{2}$ NPs in this application. 


\section{Summary}

Chlamydia species are Gram-negative, obligate, intracellular pathogens. They have to use their host cell's energy resources, because they are unable to synthesize their ATP. For this reason Chlamydiae were once considered viruses. The species of chlamydia, Chlamydia trachomatis and Chlamydia pneumoniae are known human pathogens and Chlamydia psittaci is the pathogenic agent of ornithosis or psittacosis, a primarily avian respiratory disease which can manifest as a zoonotic disease in humans. C. trachomatis has several serovariants based on the features of their major outer membrane protein. Trachoma is caused by serovars A, B and C. Serovars D to K infect ophthalmic, genital and rectal columnar epithelial cells leading to conjunctivitis, urethritis, cervicitis and proctitis, respectively. These serovars also infect respiratory epithelial cells and cause infant pneumonitis. Serovars L1-L3 cause lymphogranuloma venereum (LGV). As C. trachomatis and C. pneumoniae are frequent pathogens development of systems allowing high-throughput evaluation of chlamydial growth influencing bioactive agents is desirable.

Discovery of novel antimicrobial compounds for treatment and possible chemoprevention is a medically important research task. High-throughput testing of potentially antichlamydial compounds is hampered by the small size and obligate intracellular propagation of the bacterium. After infecting the host cell, the chlamydia propagates in a distinct cellular space called an inclusion. Since, at a low multiplicity of infection (MOI), one chlamydia can form one inclusion, the original chlamydia count is indirectly measured by labeling and manual microscopy counting of inclusions. To circumvent the labor-intensive and subjective manual counting, we designed a relatively low-cost, easy-to-use system that automatically counts chlamydial inclusions. The system consists of a commercial DNA chip scanner and custom made image analysis software. We applied this system to detect fluorescently labeled chlamydial inclusions in host cells propagated in a 16-well chamber slide. We designed ChlamyCount, a custom ImageJ plug-in for the completely automatic detection of fluorescently labeled chlamydial inclusions on the scanned image. The image processing with ChlamyCount is almost fully automatic, including the extraction of the areas of the 16 wells, the automatic detection of inclusions in each well, dissection and counting of individual inclusions, and automatic reporting. ChlamyCount was successfully used to determine the MICs of the known antichlamydial antibiotics tetracycline and moxifloxacin and the novel 
antimicrobial compound PCC00213. ChlamyCount was also applicable to evaluate of the effect of compounds that indirectly influence the chlamydial growth cycle, such as gamma interferon (IFN- $\gamma$ ), DEAE-dextran, and cycloheximide.

In conclusion, we developed an easily useable, accurate system for measuring the antichlamydial effects of known and novel antibiotics and for measuring the effects of various compounds on chlamydial growth. We think that ChlamyCount has the potential to be further optimized. An extended dynamic range of detection and absolute inclusion number estimation may be achieved by applying new raw image-processing methods and an improved confluent area dissection algorithm, goals we are currently pursuing.

Titanium-dioxide $\left(\mathrm{TiO}_{2}\right)$ is a frequently used whitening agent and food additive (E171), with an average daily consumption of 0.2-2 $\mathrm{mg} /$ body weight $(\mathrm{kg})$. E171 contains various sizes of $\mathrm{TiO}_{2}$ particles ranging from 60 to $300 \mathrm{~nm}$. Apart from the larger particles, approximately 5$15 \%$ of E171 and E171 containing foods contain below $100 \mathrm{~nm}$ diameter nano-sized $\mathrm{TiO}_{2}$ particles. Some study showed that the orally administered $\mathrm{TiO}_{2} \mathrm{NPs}$ could be detected in the liver, spleen, kidneys and lung tissues. In a study, 54-86\% of the $\mathrm{TiO}_{2}$ was found in various organs 90 days after intravenous administration. Besides the above-mentioned applications, $\mathrm{TiO}_{2}$ NPs can also be used intravenously as a drug delivery vehicle. $\mathrm{TiO}_{2} \mathrm{NPs}$ have been used to deliver various drugs including paclitaxel, 5-fluorouracil, doxorubicin and antisense oligonucleotides. Although UV-activated $\mathrm{TiO}_{2}$ NPs have a strong oxidative potential responsible for its well-described antimicrobial activity, the food additive and drug delivery application do not require activation.

We assessed the antimicrobial effects of non-activated $\mathrm{TiO}_{2}$ NPs against $C$. trachomatis and HSV-2. We demonstrated that non-activated $\mathrm{TiO}_{2}$ NPs increased $C$. trachomatis growth in a concentration-dependent manner, with an approximately four-fold increase at $100 \mu \mathrm{g} / \mathrm{ml}$ concentration. This effect was pathogen-specific, since $\mathrm{TiO}_{2} \mathrm{NPs}$ did not increase HSV-2 replication. Our above results point to the potential side effect of food or drug additives. 


\section{The following results are considered novel:}

- We designed ChlamyCount, a low-cost, medium-throughput Chlamydia growthmonitoring method. ChlamyCount is based on the cultivation and infection of host cells in chamber-slides, immunofluorescent labeling, scanning and computer-assisted counting of chlamydial inclusions. The ChlamyCount method was suitable to rapidly determine the growth of both $C$. trachomatis and $C$. pneumonia over a 1-log-unit dynamic range.

- ChlamyCount was also suitable to identify the MICs of the well-characterized antichlamydial antibiotics tetracycline, moxifloxacin and also the MIC values of novel antichlamydial compounds.

- Based on ChlamyCount and qPCR measurements, we demonstrated that the nonactivated $\mathrm{TiO}_{2}$ NPs significantly increased the $C$. trachomatis growth in a concentration-dependent manner. The growth-promoting effect was pathogen-specific, since $\mathrm{TiO}_{2}$ NPs did not increase HSV-2 replication.

- We found, that the incorporation of $\mathrm{TiO}_{2}$ significantly decreased the antimicrobial activity of $\mathrm{TiO}_{2}-\mathrm{Ag}$ NPs against both $C$. trachomatis and HSV-2 compared to the AgNPs. 


\section{7. Összefoglalás}

A Chlamydia fajok Gram-negatív, obligát, intracelluláris patogének. A gazdasejt energiakészleteit használják fel életben maradásukhoz, mivel nem képesek az ATP szintézisre. Emiatt a kezdetben vírusként definiálták őket. A Chlamydia trachomatis (C. trachomatis) és Chlamydia pneumoniae (C. pneumoniae) ismert humánpatogén kórokozók, a Chlamydia psittaci (C. psittaci) az ornithozis vagy psittacosis okozója, mely egy primer madár légúti megbetegedés, emellett képes zoonózisként manifesztálódni humán szervezetben is. A C. trachomatis-nak számos szerovariánsa van, melyeket a külső membrán fehérjék szerint csoportosítottak. Az A, B, Ba és C szerovariánsok okozzák a trachomát, amely a vezető oka a megelőzhető vakságnak, és endémiás a harmadik világ országaiban. A D-K szerovariánsok a leggyakoribb okozói a szexuálisan átvihető genitális fertőzéseknek világszerte: cervicitist, endometritis/salpingitist okoznak nőkben és urethritist nőkben és férfiakban is. Ezek a szerovariánsok légzőszervi megbetegedéseket is képesek okozni csecsemőkben. Az L1-L3 szerovariánsok a lymphogranuloma venereumot okozzák. Mivel a C. trachomatis és a $C$. pneumoniae fertőzések gyakoriak, fontos egy gyors és nagy mennyiségü minta feldolgozására képes vizsgálati módszer kialakítása, a különböző bioaktív anyagok chlamydia fertőzések elleni hatásának vizsgálatára.

Újabb antimikrobás anyagok felfedezése orvostudományi szempontból fontos kutatási terület, kezelések és lehetséges prevenció tekintetében. Potenciális chlamydia ellenes anyagok nagy mintaszámot igénylő vizsgálata nehézkes a baktérium obligát intracelluláris volta és kicsi mérete miatt. A vizsgálatokat sejtkultúrában végeztük. A gazdasejt megfertőzése után a chlamydia jól körülhatárolt zárványt hoz létre. Mivel alacsony multiplicitású fertőzés (MOI) esetében egy chlamydia sejt egy zárványt tud képezni, az eredeti baktérium mennyiséget indirekt módon, immunfluoreszcens jelölést követően, manuális mikroszkópos számolással tudjuk meghatározni. A munkaigényes és szubjektív kiértékelési folyamat helyett kifejlesztettünk egy aránylag olcsó, könnyen használható módszert, mellyel automatizáltuk a számolást. A rendszer DNS chip szkennerből és egy általunk fejlesztett képanalizáló szoftverből áll. Ezt a módszert fluoreszcensen jelölt chlamydia zárványok számolására használtuk, a fertőzést egy 16 szeparált mélyedéssel rendelkező szövettenyésztő tárgylemezen (chamber slide) végeztük. A szkennelt képek analízisét az ImageJ programba beilleszthető általunk létrehozott ChlamyCount bővítménnyel végeztük. A képek feldolgozása szinte teljes 
mértékben automatikusan történt, a 16 sejtes terület kiemelését, az zárványok detektálását, kivágását és a számolását is beleértve. A ChlamyCount eredményesnek bizonyult antibiotikumok MIC értékének meghatározására is, mint például a tetraciklin, moxifloxacin és egy új PCC002132 jelölésű anyag esetében is. A ChlamyCount használható volt olyan anyagok vizsgálatára is, melyek indirekten befolyásolják a chlamydia szaporodási ciklusát, mint például a gamma interferon, a DEAE-dextrán vagy a cikloheximid.

Könnyen használható és pontos rendszert fejlesztettünk ki, mellyel ismert és új antibiotikumok chlamydia ellenes hatását és különbözö vegyületek baktériumnövekedésre gyakorolt hatását vizsgálhatjuk. További céljaink új nyersképfeldolgozást és javított terület kivágási algoritmus kifejlesztése, kiterjesztett dinamikus tartomány és abszolút zárványbecslés érdekében.

A titán-dioxid $\left(\mathrm{TiO}_{2}\right)$ gyakran alkalmazott fehér színt biztosító adalék (pl.: kozmetikumok) és élelmiszer adalékanyag (E171), átlagosan napi 0,2-2 mg/testsúly kilogramm bevitellel. Az E171 adalékanyag különböző méretű $\mathrm{TiO}_{2}$ részecskéket tartalmaz, 60 és 300 nm között. Eltekintve a nagyobb részecskéktöl, az E171 és az E171 adalékanyagot tartalmazó ételek 5-15\%-a 100 nm-nél kisebb $\mathrm{TiO}_{2}$ nanorészecskéket tartalmaznak. Némely tanulmányok azt bizonyítják, hogy orálisan beadott $\mathrm{TiO}_{2}$-t tudtak kimutatni a máj, lép, vese és a tüdő szövetekből. Másik tanulmány szerint, az intravénásan beadott $\mathrm{TiO}_{2} 90$ nap után a szervezet számos szövetében kimutatható volt. Az említett alkalmazási területeken kívül a $\mathrm{TiO}_{2}$ intravénás gyógyszerek hordozóanyagaként is ismert. A $\mathrm{TiO}_{2}$ nanorészecskék számos gyógyszer hordozóanyagaként használatosak, mint a paclitaxel, 5-fluorouracil és az antiszensz oligonukleotidok. Az UV fény által aktivált $\mathrm{TiO}_{2}$ nanorészecskéknek erős az oxidációs potenciálja, mely a jól ismert antimikrobás hatásért felelős, az élelmiszer adalékanyagként és gyógyszer hordozóanyagként való alkalmazásához erre az aktivitásra nincs szüksége.

Kísérleteink során a nem aktivált $\mathrm{TiO}_{2}$ hatásának vizsgálatát tüztük ki célul a $C$. trachomatissal és a HSV-2-vel szemben. Azt bizonyítottuk be, hogy a $\mathrm{TiO}_{2}$ nanorészecskék koncentrációtól függően emelik a $C$. trachomatis szaporodását, megközelítőleg négyszeres mértékben $100 \mu \mathrm{g} / \mathrm{ml} \mathrm{TiO}_{2}$ koncentrációnál. Ez a hatás patogénfüggő, mivel a HSV-2 fertőzés esetében nem figyelhettünk meg ilyen hatást. Eredményeink szerint nem várt mellékhatásra mutatunk rá egy élelmiszeradalék és gyógyszer hordozóanyag esetében. 


\section{Acknowledgements}

I would like to thank all of the people who have helped and inspired me during my Ph.D studies. I would like express to my deep and sincere gratitude to my supervisors Prof. Dr. Judit Deák and Dr. Dezsö Virok for their support, wide knowledge, trust and encouragement.

I greatly acknowledge Dr. Katalin Burián, Head of the Department of Microbiology and Immunology who gave me opportunity to work at the Department.

I would like to thank to Dr. Valéria Endrész for all the help, advices and friendly atmosphere during my Ph.D studies.

I am grateful to Professor Yvette Mándi, former Head of the Doctoral School of Interdisciplinary Medicine for all the help.

I would like to thank to Dr. Edit Urbán, Head of the Institute of Clinical Microbiology for the advices.

In addition, I would like to thank my colleagues and friends Dr. Tímea Mosolygó PhD, Dr. Ágnes Míra Szabó, Ildikó Lantos, Dr. Gabriella Spengler, Annamária Kincses, Szilvia Batki, and Tímea Raffai for all the help, entertainment and care they provided.

This $\mathrm{Ph} . \mathrm{D}$ project would not have been possible to complete without the assistance and work of Tilda Lévai, Györgyi Deák, Kitti Ürmös and Anikó Váradi.

Colleagues and staff members at the Department of Medical Microbiology and Immunobiology and the Institute of Clinical Microbiology are gratefully thanked for creating a supportive and pleasant environment.

I would like to thank to Dr. Tibor Valyi-Nagy, Dr. Klara Valyi-Nagy and Deepak Shukla Ph.D for the help and encouragement at the University of Illinois at Chicago. I also would like to say thank you for Ferencz and Diane Rosztoczy and for The Rosztoczy Foundation which gave me the opportunity to worked and studied at the UIC and lived in Chicago.

I express my deepest thanks to my husband, Attila Varga-Bogdanov, for his love, patience during my Ph.D studies and who have always encouraged and believed in me.

Last, but not least I express warm thanks to my parents Judit Bócsik and Tamás Szpisják, my sister Nora Szpisják, my whole family and my best friend Katalin Polczer for all their love, patience and encouragement.

\section{I dedicate this thesis to them}




\section{References}

1. Sachse K, Bavoil PM, Kaltenboeck B, et al. Emendation of the family Chlamydiaceae: Proposal of a single genus, Chlamydia, to include all currently recognized species. Syst Appl Microbiol. 2015; 38(2):99-103.

2. Salamin N, Bertelli C, Greub G, Pillonel T. Taxogenomics of the order Chlamydiales. Int J Syst Evol Microbiol. 2015; 65(4):1381-1393.

3. Hogerwerf L, De Gier B, Baan B, Van Der Hoek W. Chlamydia psittaci (psittacosis) as a cause of community-acquired pneumonia: a systematic review and meta-analysis. Epidemiol Infect. 2017; :1-10.

4. Bastidas RJ, Elwell CA, Engel JN, Valdivia RH. Chlamydial Intracellular Survival Strategies. Cold Spring Harb Perspect Med. 2013; 3(5):a010256-a010256.

5. Schoborg RV. Chlamydia persistence - a tool to dissect chlamydia-host interactions. Microbes Infect. 2011; 13(7):649-662.

6. Mpiga P, Ravaoarinoro M. Chlamydia trachomatis persistence: An update. Microbiol Res. 2006; 161(1):9-19.

7. Witkin SS, Minis E, Athanasiou A, Leizer J, Linhares IM. Chlamydia trachomatis: the Persistent Pathogen. Papasian CJ, editor. Clin Vaccine Immunol. 2017; 24(10):e0020317.

8. Zheng J, Ding T, Chen Z, et al. Preparation and evaluation of monoclonal antibodies against chlamydial protease-like activity factor to detect Chlamydia pneumoniae antigen in early pediatric pneumonia. Eur J Clin Microbiol Infect Dis. 2015; 34(7):1319-1326.

9. Kalman S, Mitchell W, Marathe R, et al. Comparative genomes of Chlamydia pneumoniae and C. trachomatis. Nat Genet. 1999; 21(4):385-389.

10. Cao J, Mao Y, Dong B, Guan W, Shi J, Wang S. Detection of specific Chlamydia pneumoniae and cytomegalovirus antigens in human carotid atherosclerotic plaque in a chinese population. Oncotarget [Internet]. 2017 [cited 2017 Oct 30]; . Available from: http://www.oncotarget.com/fulltext/19314

11. Khan S, Imran A, Khan AA, Abul Kalam M, Alshamsan A. Systems Biology Approaches for the Prediction of Possible Role of Chlamydia pneumoniae Proteins in the Etiology of Lung Cancer. Maki CG, editor. PLOS ONE. 2016; 11(2):e0148530.

12. Hua-Feng X, Yue-Ming W, Hong L, Junyi D. A meta-analysis of the association between Chlamydia pneumoniae infection and lung cancer risk. Indian J Cancer. 2015; 52(6):112. 
13. Nakou A, Papaparaskevas J, Diamantea F, Skarmoutsou N, Polychronopoulos V, Tsakris A. A prospective study on bacterial and atypical etiology of acute exacerbation in chronic obstructive pulmonary disease. Future Microbiol. 2014; 9(11):1251-1260.

14. Paplińska-Goryca M, Rubinsztajn R, Nejman-Gryz P, Przybyłowski T, Krenke R, Chazan R. The association between serological features of chronic Chlamydia pneumoniae infection and markers of systemic inflammation and nutrition in COPD patients. Scand J Clin Lab Invest. 2017; :1-7.

15. Muro S, Tabara Y, Matsumoto H, et al. Relationship Among Chlamydia and Mycoplasma Pneumoniae Seropositivity, IKZF1 Genotype and Chronic Obstructive Pulmonary Disease in A General Japanese Population: The Nagahama Study. Medicine (Baltimore). 2016; 95(15):e3371.

16. Assar O, Nejatizadeh A, Dehghan F, Kargar M, Zolghadri N. Association of Chlamydia pneumoniae Infection With Atherosclerotic Plaque Formation. Glob J Health Sci. 2015; 8(4):260.

17. El Yazouli L, Hejaji H, Elmdaghri N, Aroussi Alami A, Dakka N, Radouani F. Investigation of Chlamydia pneumoniae infection in Moroccan patients suffering from cardiovascular diseases. J Infect Public Health [Internet]. 2017 [cited 2017 Oct 30]; . Available from: http://linkinghub.elsevier.com/retrieve/pii/S1876034117302101

18. El Yazouli L, Criscuolo A, Hejaji H, et al. Molecular characterisation of Chlamydia pneumoniae associated to atherosclerosis. Pathog Dis [Internet]. 2017 [cited 2017 Oct 30]; 75(4). Available from: https://academic.oup.com/femspd/articlelookup/doi/10.1093/femspd/ftx039

19. Fredlund H, Falk L, Jurstrand M, Unemo M. Molecular genetic methods for diagnosis and characterisation of Chlamydia trachomatis and Neisseria gonorrhoeae: impact on epidemiological surveillance and interventions. APMIS. 2004; 112(11-12):771-784.

20. Schachter J, Caldwell HD. Chlamydiae. Annu Rev Microbiol. 1980; 34:285-309.

21. Satpathy G, Behera H, Ahmed N. Chlamydial eye infections: Current perspectives. Indian J Ophthalmol. 2017; 65(2):97.

22. Haar K, Bremer V, Houareau C, et al. Risk factors for Chlamydia trachomatis infection in adolescents: results from a representative population-based survey in Germany, 2003-2006. Euro Surveill Bull Eur Sur Mal Transm Eur Commun Dis Bull. 2013; 18(34).

23. Moazenchi M, Totonchi M, Salman Yazdi R, et al. The impact of Chlamydia trachomatis infection on sperm parameters and male fertility: A comprehensive study. Int J STD AIDS. 2017; :95646241773524.

24. Manavi K. A review on infection with Chlamydia trachomatis. Best Pract Res Clin Obstet Gynaecol. 2006; 20(6):941-951. 
25. Wesbonk J, Chmiel C, Rosemann T, Seidenberg A, Senn O. Prevalence and Determinants of Sexually Transmitted Infections in Women at Risk Undergoing Abortion in a Swiss Primary Care Setting. PRAXIS. 2014; 103(15):875-882.

26. Pérez Sánchez LE, Hernández Barroso M, Hernández Hernández G. Rectal inflammatory stenosis secondary to Chlamydia trachomatis: a case report. Rev Esp Enfermedades Dig [Internet]. 2017 [cited 2017 Oct 30]; 109. Available from: https://online.reed.es/fichaArticulo.aspx?iarf=684769746238-413272192161

27. Hartog JE den, Morré SA, Land JA. Chlamydia trachomatis-associated tubal factor subfertility: Immunogenetic aspects and serological screening. Hum Reprod Update. 2006; 12(6):719-730.

28. Siemer J, Theile O, Larbi Y, et al. Chlamydia trachomatis infection as a risk factor for infertility among women in Ghana, West Africa. Am J Trop Med Hyg. 2008; 78(2):323-327.

29. Greendale GA, Haas ST, Holbrook K, Walsh B, Schachter J, Phillips RS. The relationship of Chlamydia trachomatis infection and male infertility. Am J Public Health. 1993; 83(7):996-1001.

30. Azizi A, Ríos-Soto K, Mubayi A, Hyman JM. A risk-based model for predicting the impact of using condoms on the spread of sexually transmitted infections. Infect Dis Model. 2017; 2(1):100-112.

31. Lejelind E, Westerling R, Sjögren Fugl-Meyer K, Larsson K. Condom use among Swedes while traveling internationally: A qualitative descriptive study: Condom use during international travel. Nurs Health Sci. 2017; 19(2):257-263.

32. Enns EA, Kao S-Y, Kozhimannil KB, Kahn J, Farris J, Kulasingam SL. Using Multiple Outcomes of Sexual Behavior to Provide Insights Into Chlamydia Transmission and the Effectiveness of Prevention Interventions in Adolescents: Sex Transm Dis. 2017; 44(10):619-626.

33. Jackson JA, McNair TS, Coleman JS. Over-screening for chlamydia and gonorrhea among urban women age $\geq 25$ years. Am J Obstet Gynecol. 2015; 212(1):40.e1-40.e6.

34. Deák J, Nagy E, Veréb I, et al. Prevalence of Chlamydia trachomatis infection in a low-risk population in Hungary. Sex Transm Dis. 1997; 24(9):538-542.

35. Bakheit AHH, Al-Hadiya BMH, Abd-Elgalil AA. Azithromycin. Profiles Drug Subst Excip Relat Methodol [Internet]. Elsevier; 2014 [cited 2017 Oct 30]. p. 1-40. Available from: http://linkinghub.elsevier.com/retrieve/pii/B9780128001738000015

36. Li B, Hocking JS, Bi P, Bell C, Fairley CK. The efficacy of Azithromycin and Doxycycline Treatment for Rectal Chlamydial Infection: A Retrospective Cohort Study in South Australia: nil. Intern Med J [Internet]. 2017 [cited 2017 Oct 30]; . Available from: http://doi.wiley.com/10.1111/imj.13624 
37. Briggs GG, Freeman RK, Yaffe SJ. Drugs in pregnancy and lactation: a reference guide to fetal and neonatal risk. Tenth edition. Philadelphia: Wolters Kluwer/Lippincott Williams \& Wilkins Health; 2015.

38. Cluver C, Novikova N, Eriksson DO, Bengtsson K, Lingman GK. Interventions for treating genital Chlamydia trachomatis infection in pregnancy. Cochrane Pregnancy and Childbirth Group, editor. Cochrane Database Syst Rev [Internet]. 2017 [cited 2017 Oct 30]; . Available from: http://doi.wiley.com/10.1002/14651858.CD010485.pub2

39. Kacmar J, Cheh E, Montagno A, Peipert JF. A randomized trial of azithromycin versus amoxicillin for the treatment of Chlamydia trachomatis in pregnancy. Infect Dis Obstet Gynecol. 2001; 9(4):197-202.

40. Jacobson GF, Autry AM, Kirby RS, Liverman EM, Motley RU. A randomized controlled trial comparing amoxicillin and azithromycin for the treatment of Chlamydia trachomatis in pregnancy. Am J Obstet Gynecol. 2001; 184(7):1352-1356.

41. Budai I. Chlamydia Trachomatis: Milestones in clinical and microbiological diagnostics in the last hundred years. Acta Microbiol Immunol Hung. 2007; 54(1):522.

42. Bogdanov A, Endrész V, Urbán S, et al. Application of DNA chip scanning technology for automatic detection of Chlamydia trachomatis and Chlamydia pneumoniae inclusions. Antimicrob Agents Chemother. 2014; 58(1):405-413.

43. Ali MM, Karasneh GA, Jarding MJ, Tiwari V, Shukla D. A 3-O-Sulfated Heparan Sulfate Binding Peptide Preferentially Targets Herpes Simplex Virus 2-Infected Cells. J Virol. 2012; 86(12):6434-6443.

44. Sherris medical microbiology: an introduction to infectious diseases. 245-255 (McGraw-Hill, 2004).

45. Steiner I, Benninger F. Update on Herpes Virus Infections of the Nervous System. Curr Neurol Neurosci Rep [Internet]. 2013 [cited 2017 Oct 30]; 13(12). Available from: http://link.springer.com/10.1007/s11910-013-0414-8

46. Deigendesch N, Stenzel W. Acute and chronic viral infections. Handb Clin Neurol [Internet]. Elsevier; 2017 [cited 2017 Oct 30]. p. 227-243. Available from: http://linkinghub.elsevier.com/retrieve/pii/B9780128023952000171

47. Jaishankar D, Shukla D. Genital Herpes: Insights into Sexually Transmitted Infectious Disease. Microb Cell. 2016; 3(9):437-449.

48. Ciftci Kavaklioglu B, Coban E, Sen A, et al. Review of Viral Encephalitis Cases Seen at a Tertiary Care Center in Turkey: Focus on Herpes Simplex Type 1. Noro Psikiyatri Arsivi. 2017; 54(3):209-215.

49. Whitley RJ. Herpes Simplex Virus Infections of the Central Nervous System: Contin Lifelong Learn Neurol. 2015; 21:1704-1713. 
50. Modi S, Mahajan A, Dharaiya D, Varelas P, Mitsias P. Burden of herpes simplex virus encephalitis in the United States. J Neurol. 2017; 264(6):1204-1208.

51. Steiner I. Herpes simplex virus encephalitis: new infection or reactivation?: Curr Opin Neurol. 2011; 24(3):268-274.

52. Kimberlin DW, Whitley RJ. Neonatal herpes: What have we learned. Semin Pediatr Infect Dis. 2005; 16(1):7-16.

53. Finger-Jardim F, Avila EC, Hora VP da, Gonçalves CV, Martinez AMB de, Soares MA. Prevalence of herpes simplex virus types 1 and 2 at maternal and fetal sides of the placenta in asymptomatic pregnant women. Am J Reprod Immunol. 2017; 78(1):e12689.

54. Klein RJ. Treatment of experimental latent herpes simplex virus infections with acyclovir and other antiviral compounds. Am J Med. 1982; 73(1A):138-142.

55. Erlich KS, Mills J, Chatis P, et al. Acyclovir-Resistant Herpes Simplex Virus Infections in Patients with the Acquired Immunodeficiency Syndrome. N Engl J Med. 1989; 320(5):293-296.

56. Cirelli R, Herne K, McCrary M, Lee P, Tyring SK. Famciclovir: review of clinical efficacy and safety. Antiviral Res. 1996; 29(2-3):141-151.

57. Staikuniene J, Staneviciute J. Long-term valacyclovir treatment and immune modulation for Herpes-associated erythema multiforme. Cent Eur J Immunol. 2015; 3:387-390.

58. Luber AD, Flaherty JF. Famciclovir for treatment of herpesvirus infections. Ann Pharmacother. 1996; 30(9):978-985.

59. Nowotny J. Oxide semiconductors for solar energy conversion: titanium dioxide. Boca Raton, FL: CRC Press; 2012.

60. Lin X, Li J, Ma S, et al. Toxicity of $\mathrm{TiO}_{2}$ Nanoparticles to Escherichia coli: Effects of Particle Size, Crystal Phase and Water Chemistry. Rozhkova EA, editor. PLoS ONE. 2014; 9(10):e110247.

61. Wong M-S, Chu W-C, Sun D-S, et al. Visible-Light-Induced Bactericidal Activity of a Nitrogen-Doped Titanium Photocatalyst against Human Pathogens. Appl Environ Microbiol. 2006; 72(9):6111-6116.

62. Jovanović B. Critical review of public health regulations of titanium dioxide, a human food additive: Titanium Dioxide in Human Food. Integr Environ Assess Manag. 2015; 11(1):10-20.

63. Dudefoi W, Terrisse H, Popa AF, Gautron E, Humbert B, Ropers M-H. Evaluation of the content of $\mathrm{TiO}_{2}$ nanoparticles in the coatings of chewing gums. Food Addit Contam Part A. 2017; :1-11. 
64. Kubota S, Johkura K, Asanuma K, et al. Titanium oxide nanotubes for bone regeneration. J Mater Sci Mater Med. 2004; 15(9):1031-1035.

65. Ayon AA, Cantu M, Chava K, et al. Drug loading of nanoporous $\mathrm{TiO}_{2}$ films. Biomed Mater. 2006; 1(4):L11-L15.

66. Ma M, Kazemzadeh-Narbat M, Hui Y, et al. Local delivery of antimicrobial peptides using self-organized $\mathrm{TiO}_{2}$ nanotube arrays for peri-implant infections. J Biomed Mater Res A. 2012; 100A(2):278-285.

67. Tsapis N, Bennett D, Jackson B, Weitz DA, Edwards DA. Trojan particles: Large porous carriers of nanoparticles for drug delivery. Proc Natl Acad Sci. 2002; 99(19):12001-12005.

68. Nie S, Xing Y, Kim GJ, Simons JW. Nanotechnology Applications in Cancer. Annu Rev Biomed Eng. 2007; 9(1):257-288.

69. Liang YQ, Cui ZD, Zhu SL, Yang XJ. Characterization of self-organized $\mathrm{TiO}_{2}$ nanotubes on $\mathrm{Ti}-4 \mathrm{Zr}-22 \mathrm{Nb}-2 \mathrm{Sn}$ alloys and the application in drug delivery system. $\mathrm{J}$ Mater Sci Mater Med. 2011; 22(3):461-467.

70. Sondi I, Salopek-Sondi B. Silver nanoparticles as antimicrobial agent: a case study on E. coli as a model for Gram-negative bacteria. J Colloid Interface Sci. 2004; 275(1):177-182.

71. Veres Á, Ménesi J, Juhász Á, et al. Photocatalytic performance of silver-modified $\mathrm{TiO}_{2}$ embedded in poly(ethyl-acrylate-co-methyl metacrylate) matrix. Colloid Polym Sci. 2014; 292(1):207-217.

72. Sabet SF, Simmons J, Caldwell HD. Enhancement of Chlamydia trachomatis infectious progeny by cultivation of HeLa 229 cells treated with DEAE-dextran and cycloheximide. J Clin Microbiol. 1984; 20(2):217-222.

73. Rödel J, Woytas M, Groh A, et al. Production of basic fibroblast growth factor and interleukin 6 by human smooth muscle cells following infection with Chlamydia pneumoniae. Infect Immun. 2000; 68(6):3635-3641.

74. Burián K, Hegyesi H, Buzás E, et al. Chlamydophila (Chlamydia) pneumoniae induces histidine decarboxylase production in the mouse lung. Immunol Lett. 2003; 89(23):229-236.

75. Mucsi I, Molnár J, Motohashi N. Combination of benzo[a]phenothiazines with acyclovir against herpes simplex virus. Int J Antimicrob Agents. 2001; 18(1):67-72.

76. Mosmann T. Rapid colorimetric assay for cellular growth and survival: Application to proliferation and cytotoxicity assays. J Immunol Methods. 1983; 65(1-2):55-63. 
77. Bogdanov A, Janovák L, Lantos I, et al. Nonactivated titanium-dioxide nanoparticles promote the growth of Chlamydia trachomatis and decrease the antimicrobial activity of silver nanoparticles. J Appl Microbiol. 2017; 123(5):1335-1345.

78. Csapó E, Patakfalvi R, Hornok V, et al. Effect of pH on stability and plasmonic properties of cysteine-functionalized silver nanoparticle dispersion. Colloids Surf B Biointerfaces. 2012; 98:43-49.

79. Eszik I, Lantos I, Önder K, et al. High dynamic range detection of Chlamydia trachomatis growth by direct quantitative PCR of the infected cells. J Microbiol Methods. 2016; 120:15-22.

80. Osaka I, Hills JM, Kieweg SL, Shinogle HE, Moore DS, Hefty PS. An Automated Image-Based Method for Rapid Analysis of Chlamydia Infection as a Tool for Screening Antichlamydial Agents. Antimicrob Agents Chemother. 2012; 56(8):41844188.

81. Lundholt BK. A Simple Technique for Reducing Edge Effect in Cell-Based Assays. J Biomol Screen. 2003; 8(5):566-570.

82. Peuchant O, Duvert JP, Clerc M, et al. Effects of antibiotics on Chlamydia trachomatis viability as determined by real-time quantitative PCR. J Med Microbiol. 2011; 60(4):508-514.

83. Donati M. Comparative in-vitro activity of moxifloxacin, minocycline and azithromycin against Chlamydia spp. J Antimicrob Chemother. 1999; 43(6):825-827.

84. Shima K, Szaszak M, Solbach W, Gieffers J, Rupp J. Impact of a Low-Oxygen Environment on the Efficacy of Antimicrobials against Intracellular Chlamydia trachomatis. Antimicrob Agents Chemother. 2011; 55(5):2319-2324.

85. Ikeda-Dantsuji Y, Feril LB, Tachibana K, et al. Synergistic effect of ultrasound and antibiotics against Chlamydia trachomatis-infected human epithelial cells in vitro. Ultrason Sonochem. 2011; 18(1):425-430.

86. Welsh LE, Gaydos CA, Quinn TC. In vitro evaluation of activities of azithromycin, erythromycin, and tetracycline against Chlamydia trachomatis and Chlamydia pneumoniae. Antimicrob Agents Chemother. 1992; 36(2):291-294.

87. Byrne GI, Lehmann LK, Landry GJ. Induction of tryptophan catabolism is the mechanism for gamma-interferon-mediated inhibition of intracellular Chlamydia psittaci replication in T24 cells. Infect Immun. 1986; 53(2):347-351.

88. Thomas BJ, Evans RT, Hutchinson GR, Taylor-Robinson D. Early detection of chlamydial inclusions combining the use of cycloheximide-treated McCoy cells and immunofluorescence staining. J Clin Microbiol. 1977; 6(3):285-292.

89. Benes S, McCormack WM. Comparison of methods for cultivation and isolation of Chlamydia trachomatis. J Clin Microbiol. 1982; 16(5):847-850. 
90. Evans RT, Taylor-Robinson D. Comparison of various McCoy cell treatment procedures used for detection of Chlamydia trachomatis. J Clin Microbiol. 1979; 10(2):198-201.

91. Preocanin T, Kallay N. Point of Zero Charge and Surface Charge Density of $\mathrm{TiO}_{2}$ in Aqueous Electrolyte Solution as Obtained by Potentiometric Mass Titration. Croat Chem Acta. 2006; 79(1):95-106.

92. Wang S, Indrawati L, Wooters M, et al. A novel automated method for enumeration of Chlamydia trachomatis inclusion forming units. J Immunol Methods. 2007; 324(12):84-91.

93. Osaka I, Hefty PS. Simple Resazurin-Based Microplate Assay for Measuring Chlamydia Infections. Antimicrob Agents Chemother. 2013; 57(6):2838-2840.

94. Beeckman DSA, Meesen G, Van Oostveldt P, Vanrompay D. Digital titration: Automated image acquisition and analysis of load and growth of Chlamydophila psittaci. Microsc Res Tech. 2009; 72(5):398-402.

95. Poikonen K, Lajunen T, Silvennoinen-Kassinen S, Leinonen M, Saikku P. Quantification of Chlamydia pneumoniae in cultured human macrophages and HL cells: comparison of real-time PCR, immunofluorescence and ELISA methods: QUANTIFICATION OF C.Â PNEUMONIAE. APMIS. 2010; 118(1):45-48.

96. Southern T, Bess L, Harmon J, Taylor L, Caldwell H. Fluorometric High-Throughput Assay for Measuring Chlamydial Neutralizing Antibody. Clin Vaccine Immunol. 2012; 19(11):1864-1869.

97. Cai R, Kubota Y, Shuin T, Sakai H, Hashimoto K, Fujishima A. Induction of cytotoxicity by photoexcited $\mathrm{TiO}_{2}$ particles. Cancer Res. 1992; 52(8):2346-2348.

98. Khan ST, Ahmad J, Ahamed M, Musarrat J, Al-Khedhairy AA. Zinc oxide and titanium dioxide nanoparticles induce oxidative stress, inhibit growth, and attenuate biofilm formation activity of Streptococcus mitis. JBIC J Biol Inorg Chem. 2016; 21(3):295-303.

99. Xu Y, Wei M-T, Ou-Yang HD, et al. Exposure to $\mathrm{TiO}_{2}$ nanoparticles increases Staphylococcus aureus infection of HeLa cells. J Nanobiotechnology [Internet]. 2016 [cited 2017 Mar 23]; 14(1). Available from: http://jnanobiotechnology.biomedcentral.com/articles/10.1186/s12951-016-0184-y

100. Hybiske K, Stephens RS. Mechanisms of Chlamydia trachomatis entry into nonphagocytic cells. Infect Immun. 2007; 75(8):3925-3934.

101. Gitrowski C, Al-Jubory AR, Handy RD. Uptake of different crystal structures of $\mathrm{TiO}_{2}$ nanoparticles by Caco-2 intestinal cells. Toxicol Lett. 2014; 226(3):264-276. 
102. Söderlund G, Kihlström E. Physicochemical surface properties of elementary bodies from different serotypes of Chlamydia trachomatis and their interaction with mouse fibroblasts. Infect Immun. 1982; 36(3):893-899.

103. Kuo CC, Wang SP, Grayston JT. Effect of polycations, polyanions and neuraminidase on the infectivity of trachoma-inclusin conjunctivitis and lymphogranuloma venereum organisms HeLa cells: sialic acid residues as possible receptors for trachoma-inclusion conjunction. Infect Immun. 1973; 8(1):74-79.

104. Shimizu F, Shimizu Y, Kumagai K. Specific inactivation of herpes simplex virus by silver nitrate at low concentrations and biological activities of the inactivated virus. Antimicrob Agents Chemother. 1976; 10(1):57-63.

105. Hu RL, Li SR, Kong FJ, Hou RJ, Guan XL, Guo F. Inhibition effect of silver nanoparticles on herpes simplex virus 2. Genet Mol Res. 2014; 13(3):7022-7028.

106. Niki Y, Kimura M, Miyashita N, Soejima R. In vitro and in vivo activities of azithromycin, a new azalide antibiotic, against chlamydia. Antimicrob Agents Chemother. 1994; 38(10):2296-2299. 
I. 


\title{
Application of DNA Chip Scanning Technology for Automatic Detection of Chlamydia trachomatis and Chlamydia pneumoniae Inclusions
}

\author{
Anita Bogdanov, ${ }^{a}$ Valeria Endrész, ${ }^{\mathrm{b}}$ Szabolcs Urbán, ${ }^{\mathrm{c}}$ Ildikó Lantos, ${ }^{\mathrm{b}}$ Judit Deák, ${ }^{\mathrm{a}}$ Katalin Burián, ${ }^{\mathrm{b}}$ Kamil Önder, ${ }^{\mathrm{d}}$ Ferhan Ayaydin, ${ }^{\mathrm{e}}$ \\ Péter Balázs, ${ }^{c}$ Dezső P. Virok ${ }^{\mathrm{a}}$ \\ Institute of Clinical Microbiology, University of Szeged, Szeged, Hungary ${ }^{\mathrm{a}}$; Institute of Medical Microbiology and Immunobiology, University of Szeged, Szeged, Hungary ; \\ Department of Image Processing and Computer Graphics, Institute of Informatics, University of Szeged, Szeged, Hungary'; Department of Dermatology, Paracelsus \\ Medical University, Salzburg, Austriad; Cellular Imaging Laboratory, Biological Research Center, Hungarian Academy of Sciences, Szeged, Hungary ${ }^{\mathrm{e}}$
}

Chlamydiae are obligate intracellular bacteria that propagate in the inclusion, a specific niche inside the host cell. The standard method for counting chlamydiae is immunofluorescent staining and manual counting of chlamydial inclusions. High- or medium-throughput estimation of the reduction in chlamydial inclusions should be the basis of testing antichlamydial compounds and other drugs that positively or negatively influence chlamydial growth, yet low-throughput manual counting is the common approach. To overcome the time-consuming and subjective manual counting, we developed an automatic inclusion-counting system based on a commercially available DNA chip scanner. Fluorescently labeled inclusions are detected by the scanner, and the image is processed by ChlamyCount, a custom plug-in of the ImageJ software environment. ChlamyCount was able to measure the inclusion counts over a 1-log-unit dynamic range with a high correlation to the theoretical counts. ChlamyCount was capable of accurately determining the MICs of the novel antimicrobial compound PCC00213 and the already known antichlamydial antibiotics moxifloxacin and tetracycline. ChlamyCount was also able to measure the chlamydial growth-altering effect of drugs that influence host-bacterium interaction, such as gamma interferon, DEAE-dextran, and cycloheximide. ChlamyCount is an easily adaptable system for testing antichlamydial antimicrobials and other compounds that influence Chlamydia-host interactions.

hlamydia pneumoniae and various C. trachomatis serovars are involved in medically important human diseases. C. pneumoniae is a frequent source of community-acquired pneumonia and is suspected of participating in the pathogenesis of chronic diseases, such as asthma and atherosclerosis $(1,2)$. C. trachomatis serovars $\mathrm{A}$ to $\mathrm{C}$ are involved in trachoma pathogenesis and serovars $\mathrm{D}$ to K induce pelvic inflammatory diseases (PIDs), infertility, and reactive arthritis, while the LGV serovars are the pathogens that cause lymphogranuloma venereum, a sexually transmitted disease with systemic manifestations. The antibiotics used for therapy of chlamydia infections include tetracyclines and macrolides (3-5). While antibiotic therapy is effective in the majority of cases, tetracycline and azithromycin resistance has been reported $(6,7)$.

Discovery of novel antimicrobial compounds for treatment and possible chemoprevention is a medically important research task. High-throughput testing of potentially antichlamydial compounds is hampered by the small size and obligate intracellular propagation of the bacterium. After infecting the host cell, the chlamydia propagates in a distinct cellular space called an inclusion. Since, at a low multiplicity of infection (MOI), one chlamydia can form one inclusion, the original chlamydia count is indirectly measured by labeling and manual microscopy counting of inclusions. To circumvent the labor-intensive and subjective manual counting, we designed a relatively low-cost, easy-to-use system that automatically counts chlamydial inclusions. The system consists of a commercial DNA chip scanner and custommade image analysis software. DNA chip and microarray scanners are devices widely used for the high-resolution scanning of glass slides that contain a large number of DNA probes that bind fluo- rescently labeled cDNAs or DNAs. We applied this system to detect fluorescently labeled chlamydial inclusions in host cells propagated in a 16-well chamber slide. We designed ChlamyCount, a custom ImageJ plug-in for the completely automatic detection of fluorescently labeled chlamydial inclusions on the scanned image. ImageJ is a Java-based, platform-independent, freely available image analysis software package (8). ImageJ can be specifically tailored to a given application using user-made plug-ins. The image processing with ChlamyCount is almost fully automatic, including the extraction of the areas of the 16 wells, the automatic detection of inclusions in each well, dissection and counting of individual inclusions, and automatic reporting.

ChlamyCount was used to determine the MICs of the known antichlamydial antibiotics tetracycline and moxifloxacin and the novel antimicrobial compound PCC00213. ChlamyCount was also used to measure the effect of compounds that indirectly influence the chlamydial growth cycle, such as gamma interferon (IFN- $\gamma$ ), DEAE-dextran, and cycloheximide. The ChlamyCount ImageJ plug-in is available for noncommercial use at http://www .inf.u-szeged.hu/ipcg/projects/medical.html.

Received 3 July 2013 Returned for modification 1 August 2013

Accepted 22 October 2013

Published ahead of print 4 November 2013

Address correspondence to Dezső P. Virok, virok.dezso.peter@med.u-szeged.hu

A.B. and V.E. contributed equally to this article.

Copyright @ 2014, American Society for Microbiology. All Rights Reserved.

doi:10.1128/AAC.01400-13 


\section{MATERIALS AND METHODS}

Chlamydial strains. Two Chlamydia species were used in this study: $C$. trachomatis (serovar D, UW-3/CX reference strain, and serovar L2, strain VR-577; ATCC) and C. pneumoniae (CWL029; ATCC). The Chlamydia strains were propagated and partially purified according to methods described previously, with modifications $(9,10)$. Briefly, DEAE-dextran (45 $\mathrm{mg} / \mathrm{ml}$ in Hanks' balanced salt solution [HBSS])-treated McCoy cells were infected with $C$. trachomatis serovar D, and after a 2-day incubation in culture medium (minimal essential medium with Earle salts supplemented with $10 \%$ heat-inactivated fetal bovine serum [FBS], $0.5 \%$ glucose, $2 \mathrm{mmol} /$ liter L-glutamine, $1 \times$ nonessential amino acids, $8 \mathrm{mmol} /$ liter HEPES, $25 \mu \mathrm{g} / \mathrm{ml}$ gentamicin) in the presence of $1 \mu \mathrm{g} / \mathrm{ml}$ cycloheximide, the infected cell layers were washed with phosphate-buffered saline (PBS), frozen, and covered with $50 \mu \mathrm{l} / \mathrm{cm}^{2}$ sucrose-phosphateglutamic acid buffer (SPG). After 2 freeze-thaw cycles, the cells were collected and separated from the cell debris by a 10-min centrifugation at $800 \times$ g. C. trachomatis serovar L2 and C. pneumoniae were cultured in HEp-2 cells and partially purified and concentrated by centrifugation at 30,000 $\times$ $g$ as described previously (11).The pelleted elementary bodies (EBs) were resuspended in SPG. Stocks of chlamydial EBs were aliquoted and stored in SPG until use at $-80^{\circ} \mathrm{C}$. The titer of the infectious EBs was determined by inoculation of serial dilutions of the EB preparation onto McCoy $(C$. trachomatis) or HEp-2 (C. pneumoniae) cell monolayers grown on 13$\mathrm{mm}$-diameter coverslips. Inoculated cells were centrifuged for $1 \mathrm{~h}$ at $800 \times g$, and after $24 \mathrm{~h}$ (C. trachomatis) or $48 \mathrm{~h}$ (C. pneumoniae) of culture in cycloheximide-containing growth medium, the cells were fixed with acetone and stained with monoclonal anti-chlamydia lipopolysaccharide (LPS) antibody (AbD Serotec, Oxford, United Kingdom) and fluorescein isothiocyanate-labeled anti-mouse IgG (Sigma-Aldrich, St. Louis, MO). The number of cells containing chlamydial inclusions was counted under a UV microscope, and the titer was expressed as the number of inclusionforming units (IFU)/ml.

Culture of chlamydiae on a chamber slide. Chamber slides with 16 wells (Lab-Tek chamber slide system) consisting of a removable, plastic chamber attached to a specially treated standard glass slide were used to culture host cells for infection with the Chlamydia strains. The slides were treated with $0.01 \%$ poly-L-lysine at room temperature (RT) for $15 \mathrm{~min}$ in order to optimize cell attachment. McCoy cells were transferred into the wells of the chamber slides at a density of $3 \times 10^{4}$ cells/well in $100 \mu \mathrm{l}$ of culture medium (see above). The slides were incubated for $1 \mathrm{~h}$ at room temperature in order to reduce the edge effect $(12,13)$ and then overnight at $37^{\circ} \mathrm{C}$ under a $5 \% \mathrm{CO}_{2}$ atmosphere to obtain a $90 \%$ confluent cell layer. For C. trachomatis serovar D infection, the wells were washed with 200 $\mu \mathrm{l} /$ well of HBSS, and then a $1 \%$ DEAE-dextran solution $(80 \mu \mathrm{l} /$ well $)$ was added to all wells and the slides were incubated for $15 \mathrm{~min}$ at RT. After removal of the DEAE-dextran solution, the cells were infected at an MOI of $1 \mathrm{IFU} /$ cell in each well or with serial 2-fold dilutions of stock in SPG starting with 1 IFU/cell. SPG was added to similarly treated control wells. The chamber slides were incubated at room temperature in a vertical shaker $(180 \mathrm{rpm})$ for $2 \mathrm{~h}$. The slides infected with C. trachomatis serovar L2 at MOIs ranging from 1 IFU/cell to 1:64 IFU/cell in SPG were incubated at $35^{\circ} \mathrm{C}$ under $5 \% \mathrm{CO}_{2}$ for $2 \mathrm{~h}$ without DEAE-dextran pretreatment. For C. pneumoniae infection, the DEAE-dextran treatment was used or the slides with the C. pneumoniae stock at MOIs ranging from 1:8 to 1:512 IFU/cell were centrifuged at $400 \times g$ for $60 \mathrm{~min}$ at RT. After infection, the EB-containing inocula in the wells were replaced with a culture medium containing $1 \mu \mathrm{g} / \mathrm{ml}$ cycloheximide. The slides were incubated at $37^{\circ} \mathrm{C}$ under $5 \% \mathrm{CO}_{2}$ for 24 or $48 \mathrm{~h}$ after infection with $C$. trachomatis serovars D and L2 or C. pneumoniae, respectively, and the cells were fixed for immunofluorescence staining.

Inhibition of chlamydial growth with antibiotics and IFN- $\boldsymbol{\gamma}$. Moxifloxacin (Avelox; Bayer Pharma AG) diluted in culture medium and tetracycline hydrochloride powder (Sigma-Aldrich) dissolved in distilled water were used. Concentration ranges of 0.25 to $0.004 \mu \mathrm{g} / \mathrm{ml}$ for moxifloxacin and of 0.04 to $0.0006 \mu \mathrm{g} / \mathrm{ml}$ for tetracycline with 2 -fold dilutions were tested. The stock solution of antibacterial drug candidate PCC00213 $(10 \mathrm{mg} / \mathrm{ml})$ was prepared in dimethyl sulfoxide (DMSO) and was diluted 2-fold in DMSO to $0.156 \mathrm{mg} / \mathrm{ml}$. Cycloheximide-containing culture medium was prepared by a 100-fold dilution of the DMSO-diluted compound, resulting in a series of concentrations ranging from 100 to 1.56 $\mu \mathrm{g} / \mathrm{ml}$ with a $1 \%$ DMSO content. After infection of McCoy cells with $C$. trachomatis serovar D (MOI, 1), the culture medium with cycloheximide was supplemented with the serial 2-fold dilutions of the respective antibiotics and was added to duplicate wells. Control infected wells were cultured without adding any antibiotics; for PCC00213, 1\% DMSO-containing medium was added to the control wells. Murine IFN- $\gamma$ (Peprotech, Rocky Hill, NJ) was reconstituted according to the manufacturer's instructions, and the $20,000-\mathrm{U} / \mathrm{ml}$ stock solution was stored at $-80^{\circ} \mathrm{C}$ until use. On the day before infection, the established cell layers were treated with serial 2-fold dilutions of murine IFN- $\gamma$ over the concentration range of 100 to $0.046 \mathrm{IU} / \mathrm{ml}$. As a control, human IFN- $\gamma$ (Peprotech, Rocky Hill, $\mathrm{NJ}$ ) was also added over a concentration range of $100 \mathrm{IU} / \mathrm{ml}$ to $1.5 \mathrm{IU} / \mathrm{ml}$. After the infection procedure, IFN- $\gamma$ diluted in cycloheximide-free medium was added at the same concentration as that used for the pretreatment of cells before infection.

Immunofluorescent labeling and scanning. Cells in chamber slides infected with C. pneumoniae and C. trachomatis were evaluated by immunofluorescent staining. After removing the culture medium from the slides, the cells were washed twice with PBS (200 $\mu \mathrm{l} /$ well). Then, the chamber structure was detached from the slides and the cells were fixed with precooled $100 \%$ acetone for $10 \mathrm{~min}$ at $-20^{\circ} \mathrm{C}$. Anti-chlamydia LPS antibody (AbD Serotec, Oxford, United Kingdom) was labeled with Alexa-647, and a 1:200 dilution was used for the detection of chlamydial inclusions. After incubation for $1 \mathrm{~h}$ at $37^{\circ} \mathrm{C}$, the cells were washed three times with PBS for 7 min each time and finally with distilled water. Fluorescence signals were analyzed with an Axon GenePix Personal 4100A DNA chip scanner and GenePix Pro (version 6.1) software (Molecular Devices, Sunnyvale, CA) using the Cy5 channel and a $5-\mu \mathrm{m}$ resolution.

Image processing. The scanned images were about 50 - to $60-\mathrm{MB}$ single-image 16-bit .tiff files with an intensity dynamic range of 4 orders of magnitude. The images were processed by ChlamyCount in two phases: preprocessing and analysis. In the preprocessing phase, after loading the image, the contrast was enhanced by performing the histogram normalization method of ImageJ. Afterward, the regions of interest (ROIs) containing the areas of the 16 wells of the scanned image were cropped. The cropping scheme was specifically designed for the 16-well Lab-Tek chamber slide system. In the subsequent steps, the image of each well was processed independently. To reduce noise effects, pixels of the ROI below a predefined threshold were eliminated using the ImageJ threshold operation. The default intensity threshold was set to 15,000 , a value which was empirically determined. Nevertheless, depending on the fluorescent antibody and scanner type used, the image intensity may change; hence, the user can manually adjust the inclusion intensity and area thresholds. In a further noise-reduction step, a grey-scale morphological opening (a morphological erosion followed by a dilation) was applied, using the minimum and maximum filters of Image on a 3-by-3 window.

In the analysis phase, the images of each well were processed independently. First, a binarized copy of the result of the preprocessing phase was produced. Then, the ImageJ analyze particles function was called to encounter and outline the particles (a potential inclusion or inclusions) in the well. Since confluent inclusions of various shapes could occur, no size or circularity constraints were set during the process. In the next step, the median area of the particles was computed, and particles having an area greater than the calculated median area were further processed. If the perimeter of the particle was less than 500 pixels, then the particle was decomposed by Voronoi tessellation using the local grey-scale minima as seeds and the Euclidean distance. However, no splitting was performed if the perimeter of the particle was greater than 500 pixels, because those regions were likely to represent areas of potentially aspecific labeling of the background and/or host cells. Setting a higher-intensity threshold in the 


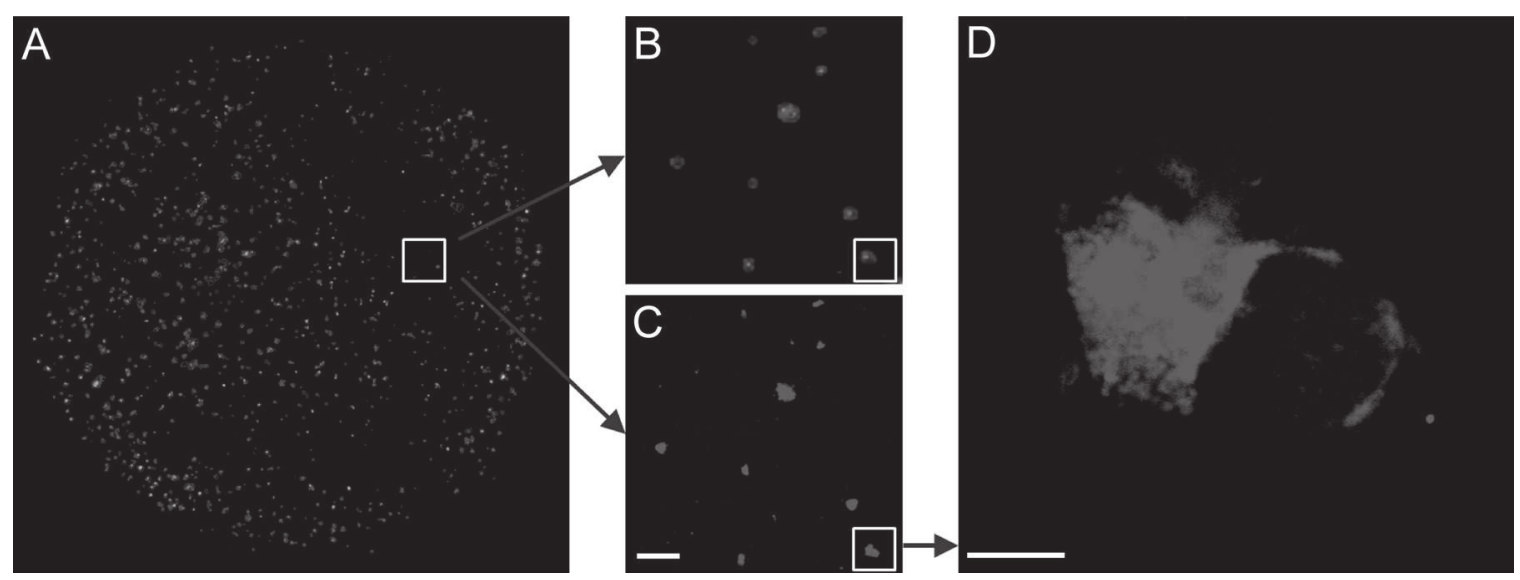

FIG 1 Comparison of the images produced by a DNA chip scanner and confocal microscopy. (A) C. trachomatis serovar D-infected McCoy cells grown in a 16-well plastic chamber attached to a glass slide. After fixation, chlamydial inclusions are fluorescently labeled and scanned by a DNA chip scanner at a 5 - $\mu \mathrm{m}$ resolution. A scanned image of a well of the 16-well chamber slide is shown. (B) Magnified portion (boxed area of panel A) of the scanned image. (C) The same boxed area from panel A visualized by fluorescent confocal laser scanning microscopy. Bar $=100 \mu \mathrm{m}$. (D) Further magnification of the fluorescent structure at the lower right of panels B and C reveals a single infected cell. Bar $=10 \mu \mathrm{m}$.

preprocessing step could reduce the occurrence of such areas. After the splitting step, the ImageJ analyze particles function was again called to identify the final number of particles and to find their boundaries, which were highlighted in red on the original grey-scale image. Finally, the result of the analysis was reported in .txt, .xls, and .pdf files. The .pdf file contains the numerical results and the processed images of the 16 areas. It should be noted that for easier visibility of the inclusions on the small-scale figures in this paper, the images of the 16 areas were further contrast enhanced using the duotone feature of PhotoFiltre image-processing software.

Confocal microscopy and imaging. Confocal laser scanning microscopy was performed using an Olympus FV1000 confocal laser scanning microscope (Olympus Life Science Europe GmbH, Hamburg, Germany). The microscope configuration was the following: objective lenses, UPLSAPO $\times$ 10 (numerical aperture [NA], 0.4), UPLSAPO $\times 20$ (NA, 0.75), and LUMPLFL $\times 40$ (NA, 0.8); sampling speed, 4 or $8 \mu \mathrm{s} /$ pixel; line averaging, $2 \times$; confocal aperture, $200 \mu \mathrm{m}$; image dimension, 512 by 512 pixels; scanning mode, sequential unidirectional; excitation, 633-nm HeNe laser; and laser transmissivity, 45\%. Alexa Fluor 647 was detected at between 645 and $745 \mathrm{~nm}$. Transmitted light images were also captured and paired with each fluorescence image using a 633 -nm laser. Using a $\times 10$ objective, 16 successive images were captured to encompass the full diameter of each well of the 16-well chamber slide. Images were stitched together to make an image strip of 512 by 8,192 pixels using the import image sequence and make montage functions of ImageJ software. Infected cells were identified and manually scored on these composite images. Since the area of the image strip is 12.2 times smaller than the area of the whole well, to estimate the approximate total number of inclusions per well, the counted inclusions were multiplied by 12.2. For close-up analyses, microscopy slides were mounted with Fluoromount-G antifade mounting solution (Southern Biotech, Birmingham, AL) and $\times 40$ immersion objective was used to capture images.

\section{RESULTS}

ChlamyCount software. McCoy epithelial cells grown on a 16well chamber slide were used for chlamydial infection. Depending on the chlamydial strain, we removed the chamber at 24 or $48 \mathrm{~h}$ postinfection (p.i.), fixed the host cells, and stained the chlamydial inclusions with Cy5 analogue Alexa 647-labeled anti-chlamydial LPS antibody. The stained inclusions were scanned with a commercially available Axon GenePix 4100 DNA chip scanner. The scanner is capable of scanning Cy3- or Cy5-labeled spots on a regular microscope glass slide with a maximum resolution of 5 $\mu \mathrm{m}$, which is comparable to the size of a chlamydial inclusion (Fig. $1 \mathrm{~A}$ to $\mathrm{D})$. The scanned image is processed by the ChlamyCount software. The thresholds for the minimum intensity and size of the inclusion are adjustable by the user; otherwise, preset threshold values are applied (Fig. 2A). The two threshold values are the only parameters that can be adjusted by the user; all the subsequent steps are automatic. If the user adjusts the intensity and/or area threshold, the effect of the adjustment can immediately be seen by a magnified quarter of the uppermost well and the well in the lowest left-hand side (Fig. 2B). In the next step, ChlamyCount automatically crops the 16 areas containing the host cells from the complete image. For each area, ChlamyCount processes the images as follows: (i) the pixels with low intensity values are likely noise; thus, they are eliminated by thresholding the image with an intensity and area threshold value; (ii) regions having an area greater than the median of the area of all regions (the suspected size of a single inclusion) are split by finding the local maxima in the regions and then assigning each point to the same closest maximum to form smaller regions; and (iii) the identified particles are encountered and their boundaries are determined. It is worth noting that the splitting of high-intensity areas is not complete; larger high-intensity areas likely to contain multiple infected cells without clear boundaries between them are regarded as one particle (inclusion). On the other hand, this effect can be observed at both higher and lower MOIs; therefore, the correlation of detected particles with the theoretical inclusion count remains. After the image analysis, ChlamyCount provides a detailed .txt and .xls output of the 16 areas with the inclusion counts; the total areas above the threshold, and, if confluent, high-intensity areas were detected and could not be dissected to individual inclusions by the software; and the total area/median area ratio is also provided. The median area size is suspected to be the area of an individual inclusion when the MOI is not high, i.e., equal to or below 1 . The third output file is a .pdf file with the above-mentioned numerical results and the processed images of the 16 areas (Fig. 2C). A typical scanning time is about $10 \mathrm{~min}$, and the image analysis time is about 1 to $5 \mathrm{~min}$. 
A

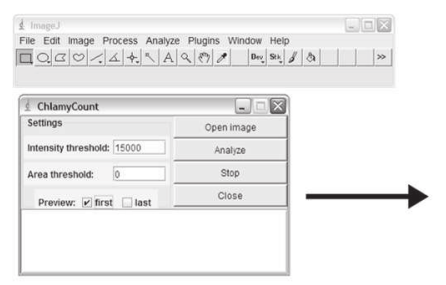

B

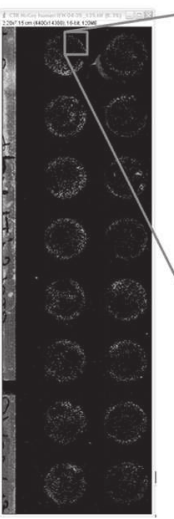

C

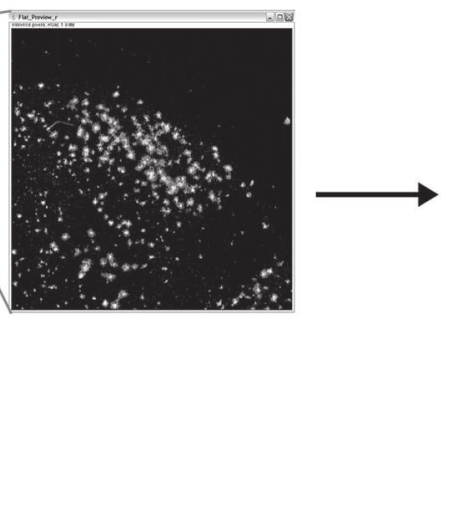

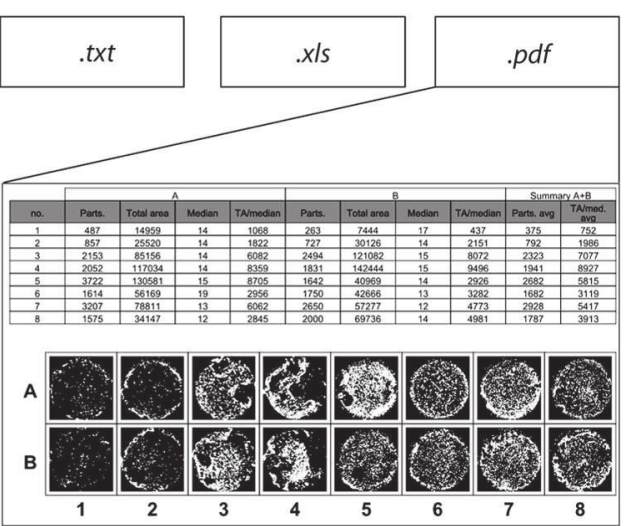

FIG 2 ChlamyCount image adjustments and report. (A) Infected host cells are grown in a 16-well chamber slide. Chlamydial inclusions are stained by direct immunofluorescence and scanned by a DNA chip scanner. Before image analysis, the user can adjust the inclusion intensity and area thresholds for detection. (B) The effect of the applied threshold changes on the number and location of the detected inclusions can be readily checked by magnification of the quadrants at the left uppermost and lowest wells of the chamber. On the basis of the applied thresholds, ChlamyCount performs the image analysis. (C) ChlamyCount reports the numerical data as .txt, .xls, and .pdf files. The .pdf file contains the numerical data as well as the images of the 16 scanned areas.

Measuring the dynamic range of detection of $C$. trachomatis serovar D, C. trachomatis serovar L2, and C. pneumoniae. The ChlamyCount system was tested on McCoy cells infected with a 1:2 dilution series of $C$. trachomatis serovar D, C. trachomatis serovar $\mathrm{L} 2$, and $C$. pneumoniae. The $C$. trachomatis serovar D infection was performed using the DEAE-dextran method, the $C$. trachomatis serovar L2 infection was performed without DEAEdextran, and the C. pneumoniae infections were performed by centrifugation $(400 \times g, 60 \mathrm{~min}, \mathrm{RT})$. Since both $C$. trachomatis serovars have a faster developmental cycle, the inclusion counting was performed at $24 \mathrm{~h}$ p.i., while for C. pneumoniae it was performed at $48 \mathrm{~h}$ p.i. Initially, the highest MOI was 8 , but between MOIs of 8 and 1 , the infected areas were highly confluent and ChlamyCount could not dissect these areas efficiently. For further experiments, the starting MOI was either 1 (C. trachomatis serovars D and L2) or 1:8 (C. pneumoniae), and 6 additional 1:2 dilutions were performed in duplicate. The last two wells contained uninfected McCoy cells (Fig. 3A to C). With all three Chlamydia species, we could measure a high correlation $\left(R^{2}=0.95\right.$ to 0.98$)$ between the measured Chlamydia inclusion count (in the report, particle count) and the theoretical inclusion count calculated from the 1:2 dilution curve. The other two calculated values, namely, the total area above the intensity threshold and the total area/median area ratios, also highly correlated with the calculated theoretical values. When no centrifugation was used for infection (C. trachomatis serovars D and L2), the inclusion counts closely followed the theoretical inclusion counts between an MOI of 1 and MOIs of 1:8 to 1:16, resulting in an approximately 1-log-unit dynamic range of the ChlamyCount system. The detected inclusion counts did not change substantially after an MOI of 1:16, marking the lower threshold of detection. The centrifugation was more efficient and permitted us to use lower MOIs for C. pneumoniae infection (Fig. 3C); however, we experienced leakage in about 25 to $30 \%$ of the chambers; hence, this infection method was not used for other experiments.

Measuring the MICs of moxifloxacin, tetracycline, and the novel antichlamydial compound PCC00213 for C. trachomatis serovar D growth. We tested whether ChlamyCount was capable of determining the MICs of the known antichlamydial antibiotics moxifloxacin and tetracycline. The $C$. trachomatis serovar D moxifloxacin MIC was previously characterized to be 0.03 to 0.05 $\mu \mathrm{g} / \mathrm{ml}(14-16)$. We performed C. trachomatis serovar D infections (MOI, 1) in the presence of moxifloxacin at concentrations ranging from $0.25 \mu \mathrm{g} / \mathrm{ml}$ to $0.04 \mu \mathrm{g} / \mathrm{ml}$. Our experiments showed (Fig. $4 \mathrm{~A}$ ) that $C$. trachomatis could grow in the presence of moxifloxacin up to a concentration of $0.015 \mu \mathrm{g} / \mathrm{ml}$ but was inhibited at a concentration of $0.031 \mu \mathrm{g} / \mathrm{ml}$, resulting in an MIC value of 0.031 $\mu \mathrm{g} / \mathrm{ml}$. Tetracyclines are first-choice antibiotics for the treatment of chlamydial infections (5). The tetracycline and doxycycline MICs for C. trachomatis serovar D were previously characterized to be 0.03 to $0.15 \mu \mathrm{g} / \mathrm{ml}(14,17,18)$. We performed C. trachomatis serovar D infections (MOI, 1) in the presence of tetracycline at concentrations ranging from $0.04 \mu \mathrm{g} / \mathrm{ml}$ to $0.0006 \mu \mathrm{g} / \mathrm{ml}$. Our experiments revealed (Fig. 4B) that $C$. trachomatis could grow in the presence of tetracycline up to a concentration of $0.01 \mu \mathrm{g} / \mathrm{ml}$ but was inhibited at a concentration of $0.02 \mu \mathrm{g} / \mathrm{ml}$, resulting in a MIC value of $0.02 \mu \mathrm{g} / \mathrm{ml}$. We also used ChlamyCount to determine the MIC of the novel antichlamydial compound PCC00213. As Fig. 4C shows, C. trachomatis could grow in the presence of PCC00213 up to a concentration of $3.1 \mu \mathrm{g} / \mathrm{ml}$ but was inhibited at a concentration of $6.2 \mu \mathrm{g} / \mathrm{ml}$, resulting in a MIC value of $6.2 \mu \mathrm{g} /$ $\mathrm{ml}$. We have to note that parallel MTT-based host cell viability assays showed that the antichlamydial effect of PCC00213 was partially due to the inhibition of host cell metabolism (data not shown). Parallel to the ChlamyCount-based MIC determination, we investigated the same slides with fluorescence microscopy and determined the inclusion counts in each chamber. As Fig. $4 \mathrm{~A}$ to $\mathrm{C}$ show, the absolute inclusion counts were generally higher when we applied ChlamyCount, but there was a high correlation between the two inclusion counts $\left(R^{2}=0.94\right.$ to 0.98 ) (Fig. 4D). Importantly, the MIC values determined by the ChlamyCount and manual methods were identical for all three tested compounds.

Measuring the effect of IFN- $\gamma$ on C. trachomatis serovar D and DEAE-dextran and cycloheximide on C. trachomatis serovar D and C. pneumoniae growth. The inhibitory activity of IFN- $\gamma$ on chlamydial growth in human host cells via the degrada- 

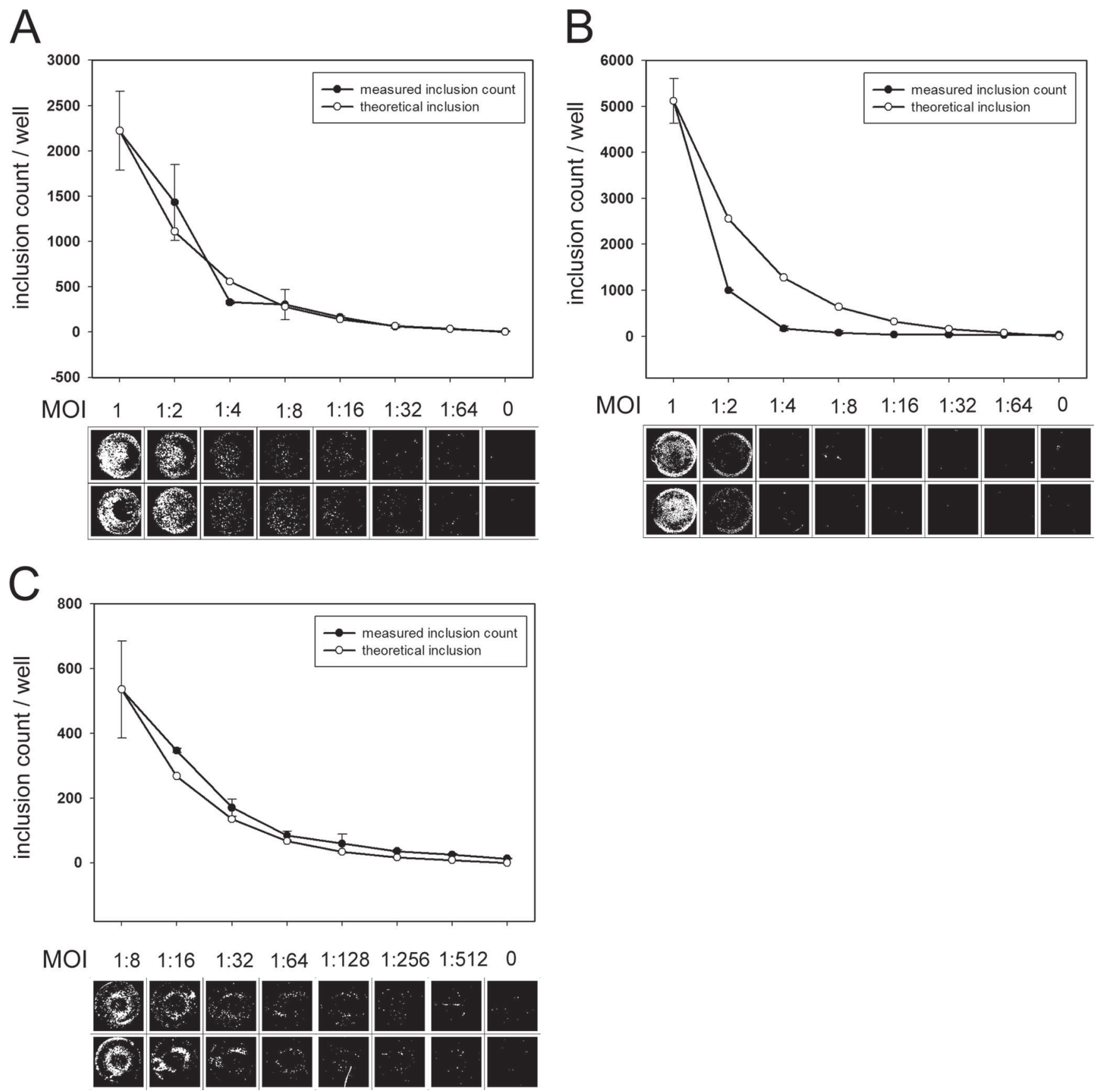

FIG 3 Detection of chlamydial inclusions. McCoy cells were infected with serially diluted C. trachomatis serovar D (A), C. trachomatis serovar L2 (B), and C. pneumoniae (C). C. pneumoniae infections were performed by centrifugation $(400 \times g, 60 \mathrm{~min}$, RT). Each infection at a particular MOI was performed in parallel wells. MOIs are shown as simple fractions instead of decimal numbers in order to follow the serial dilutions more easily. The last two wells were uninfected. The images of scanned and ChlamyCount-processed wells and the numerical data are shown for each species and serovar. For easier comparison of the theoretical and measured inclusion counts, the first theoretical inclusion count was made the same as the first measured inclusion count. Data are means \pm standard deviations for the parallel wells.

tion of the host tryptophan pool is a well-known phenomenon (19). Byrne et al. (19) found that IFN- $\gamma$ had concentration-dependent inhibitory activity on C. psittaci growth in the human uroepithelial cell line T24, resulting in an approximately 10-fold reduction of direct inclusion counts at a $20-\mathrm{ng} / \mathrm{ml}$ IFN- $\gamma$ concentration. We performed C. trachomatis infection (MOI, 1) of $\mathrm{McCoy}$ murine fibroblastoid cells in the presence of murine and human IFN- $\gamma$. Despite the fact that the host species, cell line, and chlamydial species were different from those used by Byrne et al. (19), our experiments showed a comparable extent of inhibition, albeit at a lower murine IFN- $\gamma$ concentration: inhibition of chlamydial propagation was concentration dependent, and the maximum inhibition was approximately 3.8 -fold at a murine IFN- $\gamma$ concentration of $1.5 \mathrm{IU} / \mathrm{ml}$ (approximately $0.07 \mathrm{ng} / \mathrm{ml}$ ) or higher 

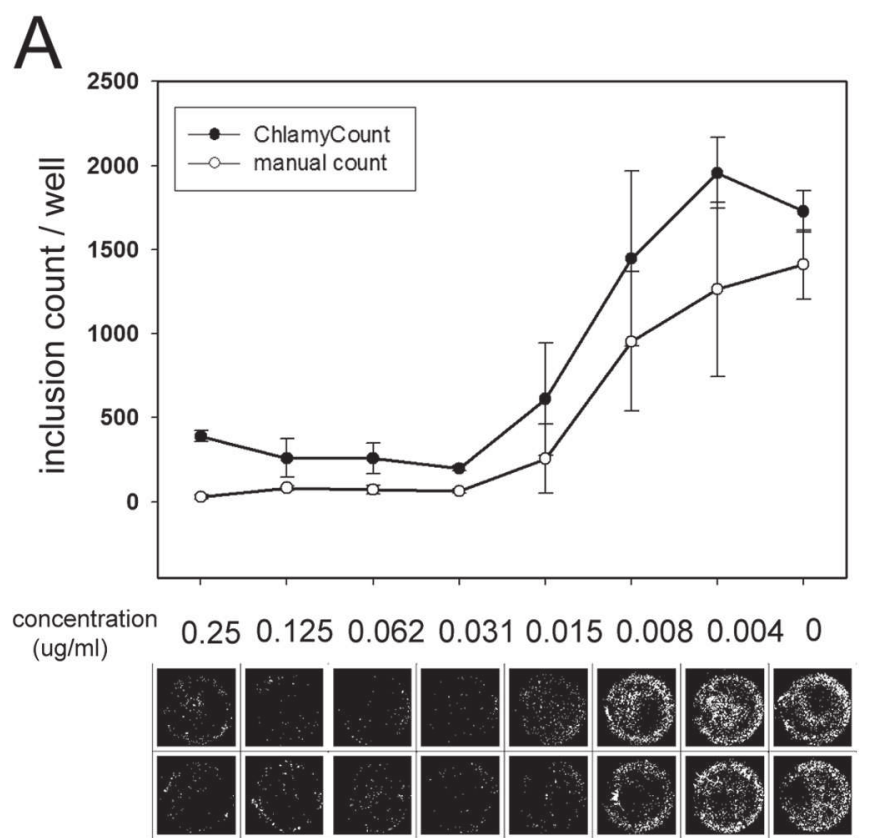

C

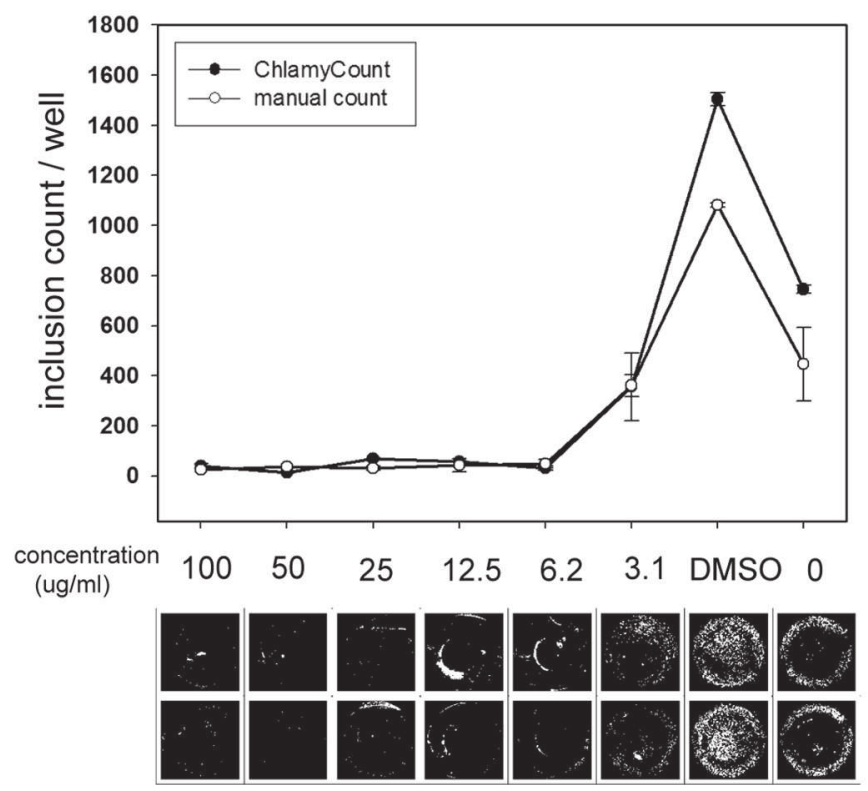

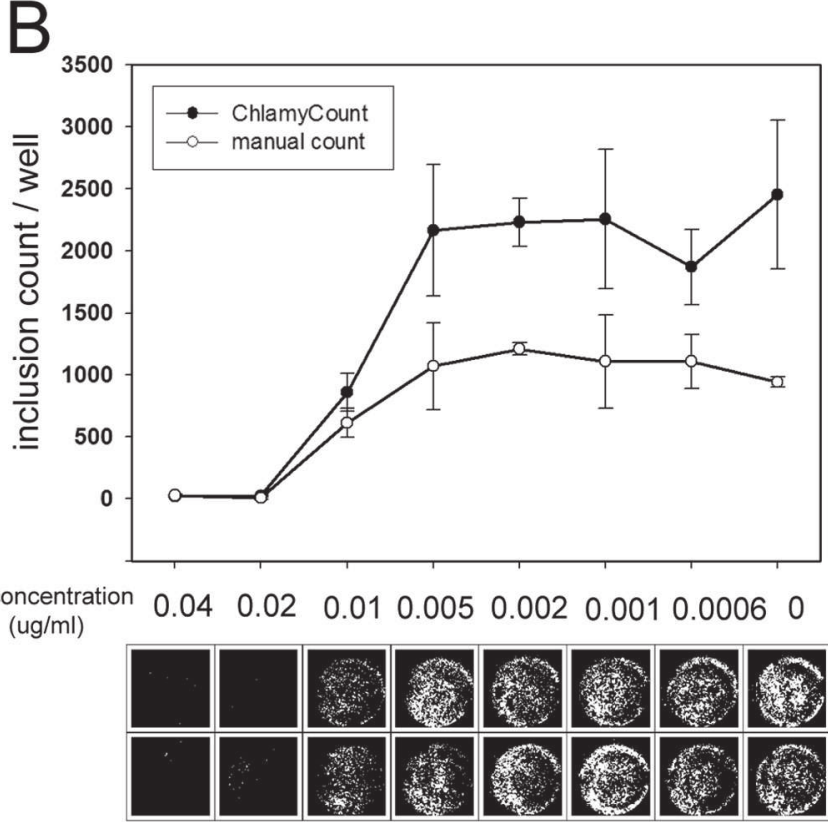
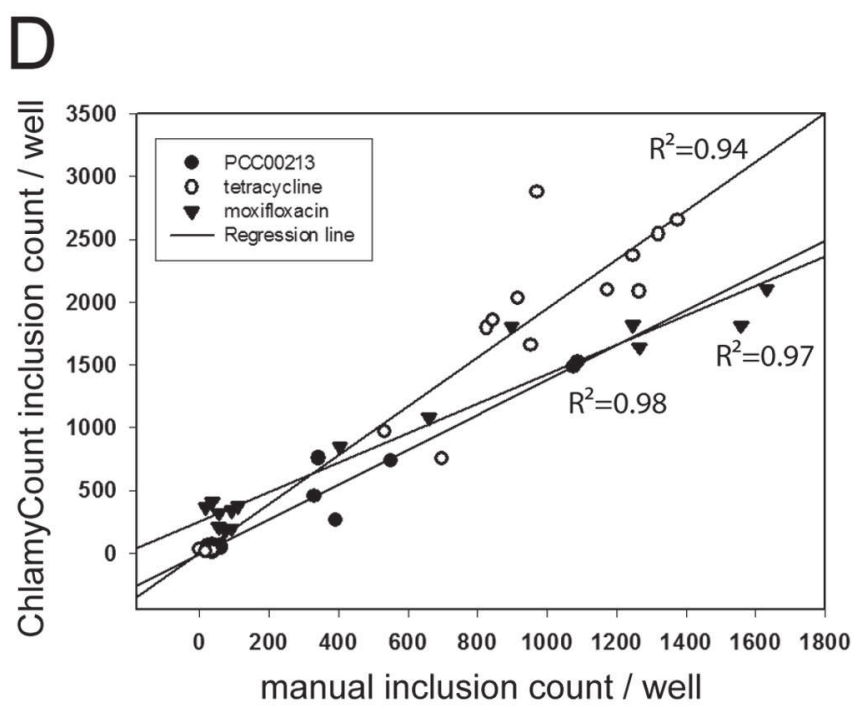

manual inclusion count / well

FIG 4 Estimation of MICs of known and novel antimicrobial compounds. McCoy cells were infected with C. trachomatis serovar D (MOI, 1) in the presence of various concentrations of moxifloxacin (A), tetracycline (B), and PCC00213 (C). Each infection with a particular antibiotic concentration was performed using parallel wells. The inclusion counts were enumerated by ChlamyCount and manual confocal microscopy on the same slide. The scanned and ChlamyCountprocessed well images and the numerical data are shown. Data are means \pm standard deviations for the parallel wells. (D) Correlation between the inclusion numbers enumerated by the ChlamyCount method and manual counting. Each data point represents the inclusion number detected in a single well of the 16-well chamber slide.

(Fig. 5A and B). The human IFN- $\gamma$ control did not show any inhibitory effect even at a concentration of $100 \mathrm{IU} / \mathrm{ml}$ (Fig. 5A). It was an early observation that the pretreatment of host cells with DEAE-dextran or treatment with cycloheximide could increase the number of chlamydial inclusions and the recoverable number of IFU $(9,20-22)$. We applied ChlamyCount to detect these effects during C. trachomatis serovar D and C. pneumoniae infection. We pretreated HeLa cells with DEAE-dextran (1\% DEAE-dextran, 15 min, RT) and/or applied $1 \mu \mathrm{g} / \mathrm{ml}$ cycloheximide during the infection and compared the direct inclusion counts to those for the untreated cells. Our results showed partially different effects of these drugs on the growth of the two Chlamydia species (Fig. 5C and D). For C. trachomatis serovar D, the application of DEAEdextran showed only a marginal effect, but the cycloheximide 
A
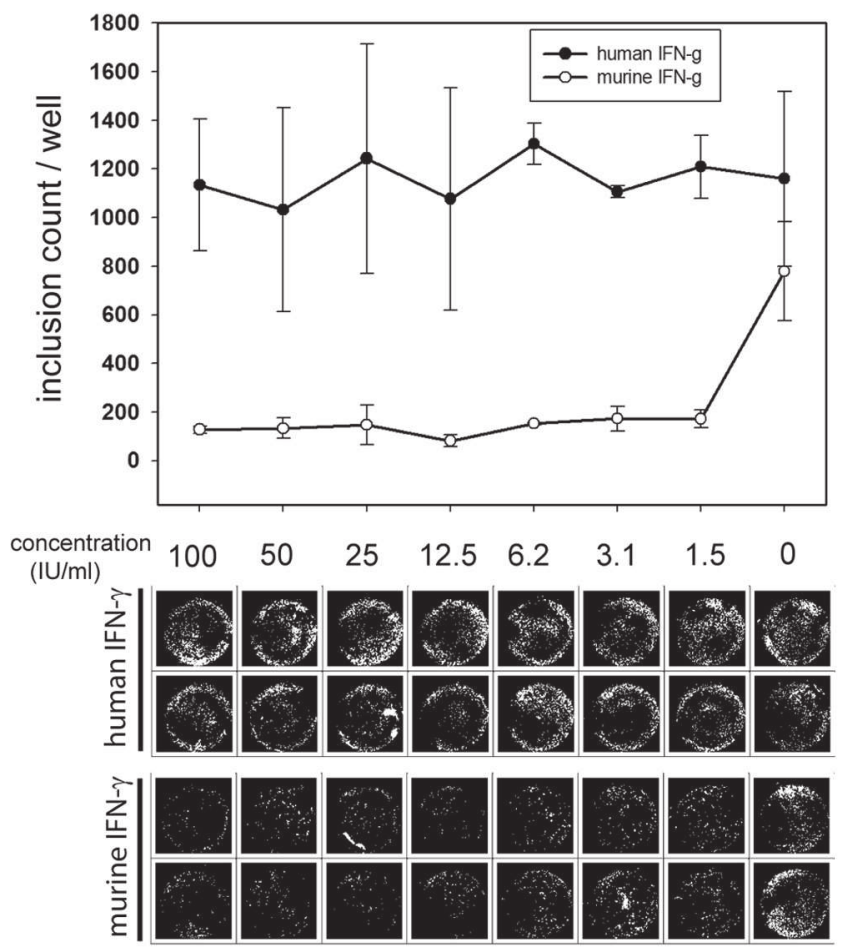

C

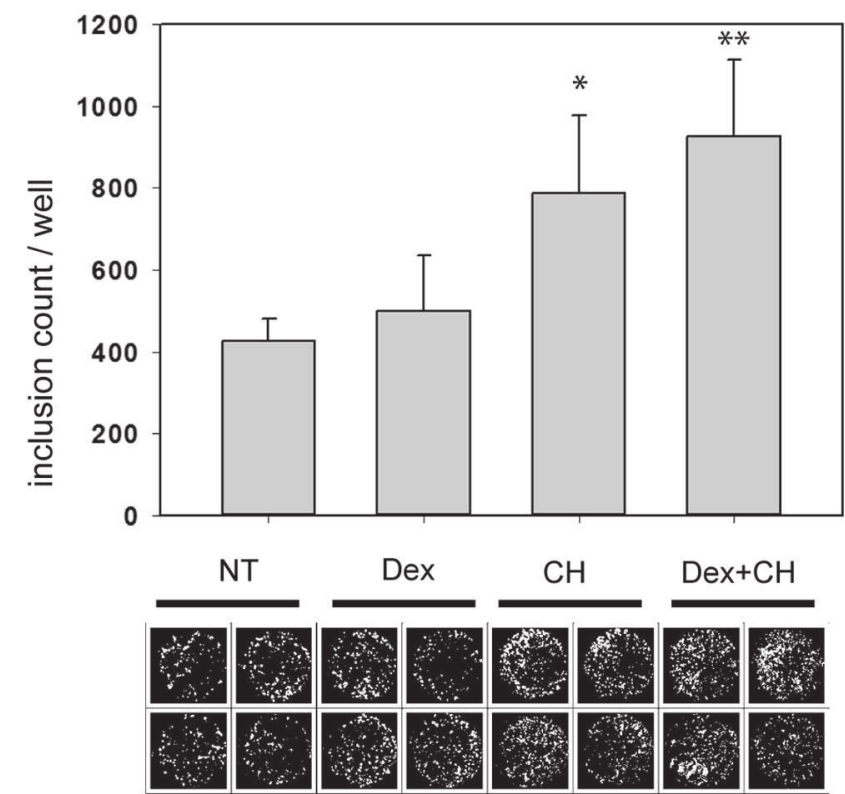

B

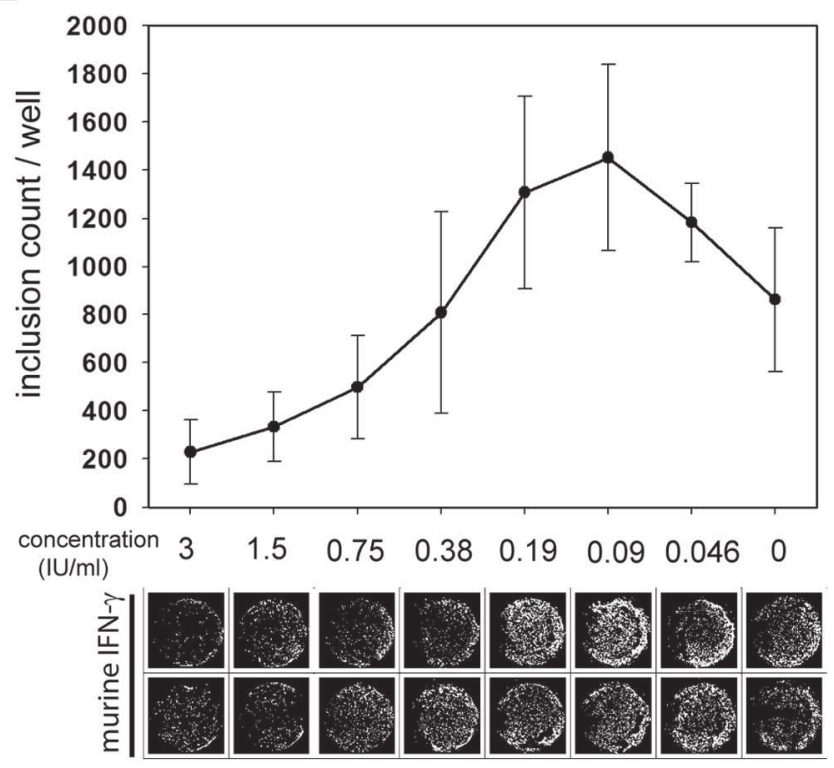

D

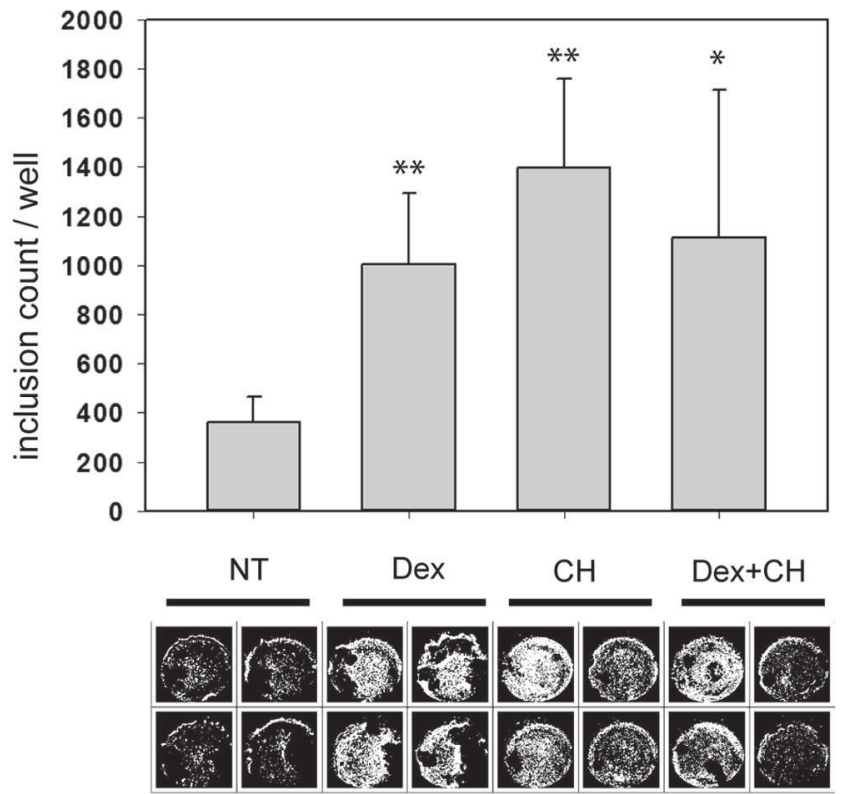

FIG 5 Measuring the effects of IFN- $\gamma$, DEAE-dextran, and cycloheximide on the direct inclusion counts of C. trachomatis serovar D and C. pneumoniae. McCoy cells were infected with $C$. trachomatis serovar D (MOI, 1) in the presence of various concentrations of human (A) and murine (A, B) IFN- $\gamma$. HeLa cells were infected with C. trachomatis serovar D (MOI, 0.5) (C) and C. pneumoniae (MOI, 1) (D) after pretreatment with $1 \%$ DEAE-dextran (15 min, RT), and/or $1 \mu \mathrm{g} / \mathrm{ml}$ cycloheximide was applied during the infection. Each infection with a particular compound concentration was performed in two parallel wells. The scanned and ChlamyCount-processed well images and the numerical data are shown. Data are means \pm standard deviations for the parallel wells. Student's $t$ test was applied for statistical comparison of the treated versus the nontreated samples. ${ }^{*}, P<0.05$; ${ }^{*}, P<0.01$. NT, nontreated; Dex, DEAE-dextran treated; CH, cycloheximide treated. The results of a representative experiment are shown. 
treatment increased the direct inclusion count 1.9- to 2.2-fold largely independently of the presence of DEAE-dextran. For $C$. pneumoniae, the application of dextran or cycloheximide alone increased the direct inclusion count 2.4- and 3.3-fold, respectively, but the coaddition of the two drugs did not show a further growth-promoting effect.

\section{DISCUSSION}

We designed a low-cost, medium-throughput method for the rapid enumeration of chlamydial inclusions. Chlamydial inclusions on a 16-well chamber slide were labeled by a fluorescently labeled genus-specific antibody and scanned by a commercial DNA chip scanner. In this detection system, the DNA chip scanner is the most expensive component; however, these scanners are easily available in core facilities, and in many cases, the new-generation sequencing technology makes these scanners infrequently used or redundant. Our technology reuses these scanners in a novel role, when the high-resolution images produced by these scanners are used to visualize chlamydial inclusions. The images are processed either completely automatically or after small intensity and area threshold adjustments on a single desktop computer with an average or low-average year 2013 hardware configuration (Intel Core2 $6600 \mathrm{CPU}$ at $2.4 \mathrm{GHz}, 2 \mathrm{~GB}$ RAM, ATI Radeon HD 3600 series video card).

The "gold standard" test of inclusion counting is the infection of host cells with serial dilutions of Chlamydia and the subsequent counting of inclusions. Our method was capable of counting 1:2 dilutions of inclusions of three different chlamydial species and provided a high correlation with the theoretical estimates. The system was capable of measuring the inclusion counts over a 1-log-unit range, which is comparable to or better than that of other previously described methods $(12,23-25)$. As with the other methods, a limitation of the ChlamyCount method at higher MOIs is the accurate dissection of the high number of confluent or nearly confluent fluorescent areas that originate from close inclusions. Also, ChlamyCount detects a higher number of inclusions than manual counting by microscopy, likely because the software detects smaller fluorescent areas as inclusions. Therefore, the current version of ChlamyCount may not be used for the absolute quantitation of inclusions. ChlamyCount was designed to measure the effect of various treatments on chlamydial growth, and for this task, it is enough to follow the changes in inclusion counts with a high degree of accuracy and it is not necessary to determine their absolute number.

Indeed, we could demonstrate that the inclusion counts detected by ChlamyCount and manual microscopy closely correlated and therefore could be applied to tasks where the detection of changes in bacterial (inclusion) counts are important, such as MIC determination. We used ChlamyCount to determine the MICs of two well-characterized antichlamydial antibiotics with different mechanisms of action: the ribosome inhibitor tetracycline and the gyrase inhibitor moxifloxacin. In both cases, ChlamyCount was able to determine that the MIC values were identical to the MIC values determined by manual microscopy and also close to the previously described values. ChlamyCount was also able to reproducibly determine the MIC value of the novel antichlamydial compound PCC00213. Besides antibiotics, various chemicals and cytokines can affect chlamydial growth in a positive or a negative manner. ChlamyCount was also able to determine the previously described inhibitory effect of IFN- $\gamma$ and the growth-promoting effect of DEAE-dextran and cycloheximide. Importantly, these data show that ChlamyCount can be used to quantitatively measure the fold changes in inclusion counts between treated and control samples. This type of relative quantitation makes our method applicable in chlamydia basic biology experiments where the effect of a given treatment should be quantitatively measured.

Considering the previously described methods, the rapid estimation of chlamydial growth can be achieved via two approaches. The first approach uses either a fluorimeter or a spectrophotometer to measure the total intensity of a Chlamydia-specific fluorescently labeled antibody (26) or indirectly measure Chlamydia growth by measuring decreased host cell metabolism after Chlamydia-induced lysis (25). These methods are rapid and inexpensive but do not rely on counting the individual inclusions; hence, the possibility of aspecific antibody binding or an aspecific change in host cell metabolism cannot be excluded. The second approach mostly $(12,24)$ but not exclusively $(23)$ uses automatic microscopes to take a certain number of images per well, followed by computer image analysis for the specific detection and enumeration of inclusions. ChlamyCount relates to these methods. Compared to the recently described automatic microscope-based inclusion counting method (12), our method has certain advantages and disadvantages. The automatic microscope-based method uses 96-well plates and obviously produces images with a higher resolution. Since analyzing the images requires significant computational power, the image analysis is performed by a computer cluster with 16 processors. In contrast, our method has a lower throughput, but the analysis time is significantly shorter; therefore, the processing time for 96 samples $(6 \times$ the 16 wells in the chambers) is comparable, at least for the first 96 samples. The ChlamyCount system set-up cost is generally lower, and the computational support required is significantly simpler. Although it has a lower resolution, ChlamyCount also preserves a major advantage of the automatic microscope-based methods; namely, it provides topological information about the inclusions. Since DNA chip scanners can scan at two different wavelengths, our method can potentially be applied to provide colocalization information, allowing, e.g., testing of the effect of anti- or prochlamydial proteins recombinantly expressed in the host cells.

In conclusion, we developed an easily useable, accurate system for measuring the antichlamydial effects of known and novel antibiotics and for measuring the effects of various compounds on chlamydial growth. We think that ChlamyCount has the potential to be further optimized. An extended dynamic range of detection and absolute inclusion number estimation may be achieved by applying new raw image-processing methods and an improved confluent area dissection algorithm, goals we are currently pursuing.

\section{ACKNOWLEDGMENTS}

This work was supported by an ERA-NET ChlamyTrans grant (to D. P. Virok), OTKA National Research Fund grant PD 100442 (to K. Burián), TÁMOP-4.2.2.A-11/1/KONV-2012-0073 (to P. Balázs), and TÁMOP4.2.2.A-11-1-KONV-2012-0035.

\section{REFERENCES}

1. Sutherland ER, Martin RJ. 2007. Asthma and atypical bacterial infection. Chest 132:1962-1966. http://dx.doi.org/10.1378/chest.06-2415.

2. Rosenfeld ME, Campbell LA. 2011. Pathogens and atherosclerosis: update on the potential contribution of multiple infectious organisms to the 
pathogenesis of atherosclerosis. Thromb. Haemost. 106:858-867. http: //dx.doi.org/10.1160/TH11-06-0392.

3. Wagenlehner FM, Wullt B, Perletti G. 2011. Antimicrobials in urogenital infections. Int. J. Antimicrob. Agents 38(Suppl):3-10. http://dx.doi .org/10.1016/j.ijantimicag.2011.09.004.

4. Campbell JP, Mkocha H, Munoz B, West SK. 2012. Two-day dosing versus one-day dosing of azithromycin in children with severe trachoma in Tanzania. Ophthalmic Epidemiol. 19:38 - 42. http://dx.doi.org/10.3109 /09286586.2011.627490.

5. Mishori R, McClaskey EL, WinklerPrins VJ. 2012. Chlamydia trachomatis infections: screening, diagnosis, and management. Am. Fam. Physician 86:1127-1132.

6. O'Neill CE, Seth-Smith HM, Van Der Pol B, Harris SR, Thomson NR, Cutcliffe LT, Clarke IN. 2013. Chlamydia trachomatis clinical isolates identified as tetracycline resistant do not exhibit resistance in vitro: wholegenome sequencing reveals a mutation in porB but no evidence for tetracycline resistance genes. Microbiology 159(Pt 4):748-756. http://dx.do .org/10.1099/mic.0.065391-0.

7. Bhengraj AR, Srivastava P, Mittal A. 2011. Lack of mutation in macrolide resistance genes in Chlamydia trachomatis clinical isolates with decreased susceptibility to azithromycin. Int. J. Antimicrob. Agents 38:178179. http://dx.doi.org/10.1016/j.ijantimicag.2011.03.015.

8. Collins TJ. 2007. ImageJ for microscopy. Biotechniques 43:25-30. http: //dx.doi.org/10.2144/000112505.

9. Sabet SF, Simmons J, Caldwell HD. 1984. Enhancement of Chlamydia trachomatis infectious progeny by cultivation of HeLa 229 cells treated with DEAE-dextran and cycloheximide. J. Clin. Microbiol. 20:217-222.

10. Rodel J, Woytas M, Groh A, Schmidt KH, Hartmann M, Lehmann M Straube E. 2000. Production of basic fibroblast growth factor and interleukin 6 by human smooth muscle cells following infection with Chlamydia pneumoniae. Infect. Immun. 68:3635-3641. http://dx.doi.org/10 .1128/IAI.68.6.3635-3641.2000.

11. Burian K, Hegyesi H, Buzas E, Endresz V, Kis Z, Falus A, Gonczol E. 2003. Chlamydophila (Chlamydia) pneumoniae induces histidine decarboxylase production in the mouse lung. Immunol. Lett. 89:229-236. http: //dx.doi.org/10.1016/S0165-2478(03)00154-8.

12. Osaka I, Hills JM, Kieweg SL, Shinogle HE, Moore DS, Hefty PS. 2012. An automated image-based method for rapid analysis of Chlamydia infection as a tool for screening antichlamydial agents. Antimicrob. Agents Chemother. 56:4184-4188. http://dx.doi.org/10.1128/AAC.00427-12.

13. Lundholt BK, Scudder KM, Pagliaro L. 2003. A simple technique for reducing edge effect in cell-based assays. J. Biomol. Screen. 8:566-570. http://dx.doi.org/10.1177/1087057103256465.

14. Peuchant O, Duvert JP, Clerc M, Raherison S, Bebear C, Bebear CM, de Barbeyrac B. 2011. Effects of antibiotics on Chlamydia trachomatis viability as determined by real-time quantitative PCR. J. Med. Microbiol. 60:508-514. http://dx.doi.org/10.1099/jmm.0.023887-0.
15. Donati M, Rodriguez Fermepin M, Olmo A, D’Apote L, Cevenini R. 1999. Comparative in-vitro activity of moxifloxacin, minocycline and azithromycin against Chlamydia spp. J. Antimicrob. Chemother. 43:825827. http://dx.doi.org/10.1093/jac/43.6.825.

16. Shima K, Szaszak M, Solbach W, Gieffers J, Rupp J. 2011. Impact of a low-oxygen environment on the efficacy of antimicrobials against intracellular Chlamydia trachomatis. Antimicrob. Agents Chemother. 55: 2319-2324. http://dx.doi.org/10.1128/AAC.01655-10.

17. Ikeda-Dantsuji Y, Feril LB, Jr, Tachibana K, Ogawa K, Endo H, Harada Y, Suzuki R, Maruyama K. 2011. Synergistic effect of ultrasound and antibiotics against Chlamydia trachomatis-infected human epithelial cells in vitro. Ultrason. Sonochem. 18:425-430. http://dx.doi.org/10.1016 /j.ultsonch.2010.07.015.

18. Welsh LE, Gaydos CA, Quinn TC. 1992. In vitro evaluation of activities of azithromycin, erythromycin, and tetracycline against Chlamydia trachomatis and Chlamydia pneumoniae. Antimicrob. Agents Chemother. 36:291-294. http://dx.doi.org/10.1128/AAC.36.2.291.

19. Byrne GI, Lehmann LK, Landry GJ. 1986. Induction of tryptophan catabolism is the mechanism for gamma-interferon-mediated inhibition of intracellular Chlamydia psittaci replication in T24 cells. Infect. Immun. 53:347-351.

20. Thomas BJ, Evans RT, Hutchinson GR, Taylor-Robinson D. 1977. Early detection of chlamydial inclusions combining the use of cycloheximidetreated McCoy cells and immunofluorescence staining. J. Clin. Microbiol. 6:285-292.

21. Evans RT, Taylor-Robinson D. 1979. Comparison of various McCoy cell treatment procedures used for detection of Chlamydia trachomatis. J. Clin. Microbiol. 10:198-201.

22. Benes S, McCormack WM. 1982. Comparison of methods for cultivation and isolation of Chlamydia trachomatis. J. Clin. Microbiol. 16:847-850.

23. Wang S, Indrawati L, Wooters M, Caro-Aguilar I, Field J, Kaufhold R, Payne A, Caulfield MJ, Smith JG, Heinrichs JH. 2007. A novel automated method for enumeration of Chlamydia trachomatis inclusion forming units. J. Immunol. Methods 324:84-91. http://dx.doi.org/10 .1016/j.jim.2007.05.004.

24. Beeckman DS, Meesen G, Van Oostveldt P, Vanrompay D. 2009. Digital titration: automated image acquisition and analysis of load and growth of Chlamydophila psittaci. Microsc. Res. Tech. 72:398-402. http://dx.doi .org/10.1002/jemt.20694.

25. Osaka I, Hefty PS. 2013. Simple resazurin-based microplate assay for measuring Chlamydia infections. Antimicrob. Agents Chemother. 57: 2838-2840. http://dx.doi.org/10.1128/AAC.00056-13.

26. Southern T, Bess L, Harmon J, Taylor L, Caldwell H. 2012. Fluorometric high-throughput assay for measuring chlamydial neutralizing antibody. Clin. Vaccine Immunol. 19:1864-1869. http://dx.doi.org/10.1128 /CVI.00460-12. 
II. 


\title{
Nonactivated titanium-dioxide nanoparticles promote the growth of Chlamydia trachomatis and decrease the antimicrobial activity of silver nanoparticles
}

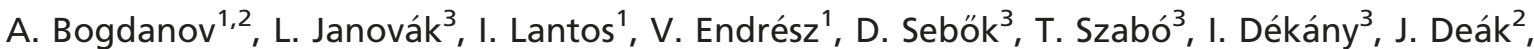 \\ Z. Rázga ${ }^{4}$, K. Burián ${ }^{1}$ and D.P. Virok ${ }^{1}$ \\ 1 Department of Medical Microbiology and Immunobiology, University of Szeged, Szeged, Hungary \\ 2 Institute of Clinical Microbiology, University of Szeged, Szeged, Hungary \\ 3 Department of Physical Chemistry and Materials Science, University of Szeged, Szeged,Hungary \\ 4 Department of Pathology, University of Szeged, Szeged, Hungary
}

\section{Keywords}

antimicrobials, Chlamydia trachomatis, food, herpes simplex, infection, nanoparticles, qPCR, titanium-dioxide.

\section{Correspondence}

Dezső P. Virok, Department of Medical Microbiology and Immunobiology, University of Szeged, Dóm sqr. 10., 6720 Szeged, Hungary.

E-mail: virok.dezso.peter@med.u-szeged.hu

2017/0656: received 4 April 2017, revised 21 July 2017 and accepted 7 August 2017

doi:10.1111/jam.13560

\begin{abstract}
Aims: Chlamydia trachomatis and herpes simplex virus (HSV) are the most prevalent bacterial and viral sexually transmitted infections. Due to the chronic nature of their infections, they are able to interact with titanium-dioxide $\left(\mathrm{TiO}_{2}\right)$ nanoparticles (NPs) applied as food additives or drug delivery vehicles. The aim of this study was to describe the interactions of these two prevalent pathogens with the $\mathrm{TiO}_{2}$ NPs.

Methods and Results: Chlamydia trachomatis and HSV-2 were treated with nonactivated $\mathrm{TiO}_{2} \mathrm{NPs}$, silver NPs and silver decorated $\mathrm{TiO}_{2}$ NPs before infection of HeLa and Vero cells. Their intracellular growth was monitored by quantitative PCR. Unexpectedly, the $\mathrm{TiO}_{2} \mathrm{NPs}\left(100 \mu \mathrm{g} \mathrm{ml}^{-1}\right)$ increased the growth of $C$. trachomatis by approximately fourfold, while the HSV-2 replication was not affected. Addition of $\mathrm{TiO}_{2}$ to silver NPs decreased their antimicrobial activity against $C$. trachomatis up to 27.92 -fold.

Conclusion: In summary, nonactivated $\mathrm{TiO}_{2} \mathrm{NPs}$ could increase the replication of $C$. trachomatis and decrease the antimicrobial activity of silver NPs.

Significance and Impact of the Study: The food industry or drug delivery use of $\mathrm{TiO}_{2} \mathrm{NPs}$ could enhance the growth of certain intracellular pathogens and potentially worsen disease symptoms, a feature that should be further investigated.
\end{abstract}

\section{Introduction}

Sexually transmitted infections (STIs) are the most prevalent infectious diseases in the world. Among the STIs, Chlamydia trachomatis-related infections are the most common ('WHO|Global prevalence and incidence of selected curable sexually transmitted infections: overview and estimates' 2001). Chlamydia trachomatis serovars $\mathrm{D}-\mathrm{K}$ cause pelvic inflammatory diseases and infertility, while the LGV serovars are the pathogens that cause lymphogranuloma venereum, an STI with systemic manifestations. Chlamydia trachomatis infections have also been linked to extra-urogenital tract diseases, such as arthritis and spondyloarthritis (Zeidler and Hudson 2016). Herpes simplex virus-1 (HSV-1) and preferentially HSV-2 genital infections are common viral STIs. The number of HSV-2 seropositive people (15-49 years) was estimated as 417 million in 2012 , with a $11.3 \%$ prevalence in the population (Looker et al. 2015). Besides the vesicular lesions of the urogenital and anal regions, HSV infections may lead to severe complications including encephalitis, meningitis and neonatal herpes infections. Both pathogens preferentially cause persistent or latent infections either locally (C. trachomatis) and/or farther from the site of the primary infection, such as in the sacral ganglia for HSV-2 and joints for C. trachomatis. 
Because of the long-term presence of the pathogens, there is a possibility that their infectious cycles, including the active and persistent growths, are influenced by locally or systematically applied compounds, including nanomaterials. Titanium-dioxide $\left(\mathrm{TiO}_{2}\right)$ is a frequently used whitening agent and food additive (E171), with an average daily consumption of $0 \cdot 2-2 \mathrm{mg}$ per body weight (kg) (Weir et al. 2012). E171 contains various sizes of $\mathrm{TiO}_{2}$ particles ranging from 60 to $300 \mathrm{~nm}$. Apart from the larger particles, approximately $5-15 \%$ of E171 and E171 containing foods contain below 100-nm diameter nano-sized $\mathrm{TiO}_{2}$ particles (Peters et al. 2014). While the primary entry of $\mathrm{TiO}_{2}$ nanoparticles (NPs) is the gastrointestinal tract, there are data indicating that the $\mathrm{TiO}_{2}$ NPs can bind to abundant serum proteins/protein fractions (Zaqout et al. 2011) and distribute to various organs, further away from the site of the administration. Indeed, Wang et al. (2007) showed that the orally administered $\mathrm{TiO}_{2}$ NPs could be detected in the liver, spleen, kidneys and lung tissues. Animal studies also show that while the oral absorption of $\mathrm{TiO}_{2}$ is low, there is a possibility of long-term accumulation because the elimination of $\mathrm{TiO}_{2}$ is also limited. In a study, 54-86\% of the $\mathrm{TiO}_{2}$ was found in various organs 90 days after intravenous administration (Geraets et al. 2014). Besides the above-mentioned applications, $\mathrm{TiO}_{2} \mathrm{NPs}$ can also be used intravenously as a drug delivery vehicle. An increasing range of disorders such as cancer, thrombosis, arthritis and diabetes mellitus can be treated by novel NP-based drug delivery systems (Tsapis et al. 2002). Due to its low toxicity, $\mathrm{TiO}_{2} \mathrm{NPs}$ can be administered in an enteral or parenteral ways, including inhalation, intravenous, intramuscular, subcutaneous and transdermal routes. $\mathrm{TiO}_{2} \mathrm{NPs}$ have been used to deliver various drugs including paclitaxel (Venkatasubbu et al. 2015), 5fluorouracil (Faria and de Queiroz 2015), doxorubicin (Shen et al. 2015) and antisense oligonucleotides (Levina et al. 2015). Although UV-activated $\mathrm{TiO}_{2} \mathrm{NPs}$ have a strong oxidative potential responsible for its welldescribed antimicrobial activity, the food additive and drug delivery application (Györgyey et al. 2016) do not require activation.

Since the daily intake of $\mathrm{TiO}_{2} \mathrm{NPs}$ is significant, and their elimination is limited, the long-term accumulation of $\mathrm{TiO}_{2} \mathrm{NPs}$ and their interaction with pathogens causing chronic infections is a real possibility. Therefore, we measured the antimicrobial effects of nonactivated $\mathrm{TiO}_{2} \mathrm{NPs}$ against $C$. trachomatis and HSV-2. We demonstrated that nonactivated $\mathrm{TiO}_{2}$ NPs increased $C$. trachomatis growth in a concentration-dependent manner, with an approximately fourfold increase at $100 \mu \mathrm{g} \mathrm{ml}^{-1}$ concentration. This effect was pathogen specific, since $\mathrm{TiO}_{2} \mathrm{NPs}$ did not increase HSV-2 replication.

\section{Materials and methods}

\section{Preparation of silver NPs (Ag NPs) and silver-modified $\mathrm{TiO}_{2} \mathrm{NPs}\left(\mathrm{TiO}_{2}-\mathrm{Ag} \mathrm{NPs}\right)$}

The Ag NPs were prepared according to our previous preparation procedure (Csapó et al. 2012). Sodium borohydride and sodium citrate were used as reducing and stabilizing agents, respectively. The initial concentration of the aqueous Ag NPs dispersion was $100 \mathrm{ppm}$ $\left(0.92 \mathrm{mmol} \mathrm{l}^{-1}\right)$, and the average particle size determined by transmission electron microscopy (TEM) was $8.2 \pm 3.34 \mathrm{~nm}$. The commercially $\mathrm{TiO}_{2}$ nanopowder from Aeroxide ${ }^{\circledR}$ P25 (Degussa-Evonik, Essen, Germany) was used. Because of its high purity, high specific surface area and unique combination of anatase and rutile crystal structure, the product has many catalytic and photocatalytic applications. In order to prepare the $\mathrm{TiO}_{2}-\mathrm{Ag} \mathrm{NPs}$, $5 \mathrm{~g}$ of $\mathrm{P}_{25} \mathrm{TiO}_{2}$ (Degussa-Evonik) was dispersed in $100 \mathrm{ml}$ of double-distilled water, then $40 \mathrm{ml}$ of $57.9 \times 10^{-3} \mathrm{mmol} \mathrm{l}^{-1} \mathrm{AgNO}_{3}$ (Reanal, Budapest, Hungary) solution was added to the suspension, and was vigorously stirred. The $\mathrm{pH}$ was adjusted to $7 \cdot 2$, and then, $60 \mathrm{ml} \quad 38.6 \mathrm{mmol} \mathrm{l}^{-1} \mathrm{NaBH}_{4} \quad$ (Reanal) solution was added dropwise to the suspension. The obtained $\mathrm{TiO}_{2}-\mathrm{Ag}$ suspension was stirred for $60 \mathrm{~min}$, washed with doubledistilled water, centrifuged, and dried (Veres et al. 2014).

\section{Transmission electron microscopy measurements of $\mathrm{TiO}_{2^{-}}, \mathrm{Ag}-$ and $\mathrm{TiO}_{2}-\mathrm{Ag} \mathrm{NPs}$}

The morphology and the particle size of the prepared $\mathrm{TiO}_{2^{-}}, \mathrm{Ag}-$ and $\mathrm{TiO}_{2}-\mathrm{Ag}$ NPs were examined by a TEM. The investigation was performed using a Tecnai G2 $20 \mathrm{X}$ Twin type instrument (FEI, Hillsboro, OR), operating at an acceleration voltage of $200 \mathrm{kV}$. The microscope was equipped with a Megaview II digital camera. For TEM measurements, the samples were sonicated in distilled water before being dropped on a copper mounted lacy carbon film (200 mesh) and dried.

\section{Surface charge measurements of the $\mathrm{TiO}_{2^{-}}, \mathrm{Ag}$ - and $\mathrm{TiO}_{2}$-Ag NPs}

Surface charge values of the NPs were measured by means of a PCD-04 particle charge detector (Mütek Analytic $\mathrm{GmbH}$, Herrsching, Germany) with manual titration. Under a titration process, the surface charge of the $\mathrm{TiO}_{2^{-}}$, Ag- and $\mathrm{TiO}_{2}-\mathrm{Ag}$ NPs were compensated with hexadecylpyridinium chloride ( $\mathrm{HDPCl})$ as opposite charged surfactants with concomitant streaming potential measurements. A $10 \mathrm{ml}$ of $100 \mu \mathrm{g} \mathrm{ml}^{-1}$ particle suspension in a sucrose-phosphate-glutamic acid buffer (SPG, 
$\mathrm{pH} 7 \cdot 4,0.25 \mathrm{~mol} \mathrm{l}^{-1}$ sucrose, $10 \mathrm{mmol} \mathrm{l}^{-1}$ sodium phosphate, $5 \mathrm{nmol} \mathrm{l}^{-1}$ glutamic acid in a distilled water) medium was measured in the particle charge detector at $\mathrm{pH}=7 \cdot 4$. In view of the amount of the $0 \cdot 01 \%$ surfactant solution added at the charge compensation point (streaming potential $=0 \mathrm{mV}$ ), the equimolar amount of surfactant was calculated and specified to the amount of particles (meq per $100 \mathrm{~g}$ ). All experiments were repeated three times.

\section{Chlamydia and herpes strains}

Chlamydia trachomatis serovar D reference strain (UW-3/ CX, ATCC) and HSV-2 (Bela Johan National Institute of Hygiene, Budapest, Hungary) were used in this study. The C. trachomatis strain was propagated and partially purified as described previously (Sabet et al. 1984). The HSV-2 strain was propagated as described previously (Blaho et al. 2005).

\section{3-(4,5-dimethyl-2-thiazolyl)-2,5-diphenyl-2H-tetrazolium bromide assay}

3-(4,5-dimethyl-2-thiazolyl)-2,5-diphenyl-2H-tetrazolium bromide (MTT) assay was performed to characterize the maximum nontoxic concentration of the NPs on HeLa cells after $48 \mathrm{~h}$ of incubation as was described previously (Párducz et al. 2016).

Culture of HeLa cells and measuring the impact of NPs on C. trachomatis growth

HeLa 229 cells were transferred into the wells of a 96-well plate at a density of $6 \times 10^{4}$ cells/well in $100 \mu \mathrm{l}$ of Dulbecco's modified Eagle's medium (Sigma) containing 5\% foetal bovine serum (Gibco-Thermo Fisher Scientific, MA, USA), $0 \cdot 14 \%$ sodium bicarbonate, $100 \mathrm{U} \mathrm{ml}^{-1}$ penicillin, $100 \mathrm{mg} \mathrm{ml}^{-1}$ streptomycin sulphate, and $250 \mathrm{mg} \mathrm{ml}^{-1}$ amphotericin-B. $\mathrm{TiO}_{2^{-}}, \mathrm{Ag}-$ and $\mathrm{TiO}_{2}-\mathrm{Ag}$ NPs were prepared in a physiological salt solution and diluted in SPG. Chlamydia trachomatis elementary bodies were incubated with the NPs for $1 \mathrm{~h}$ at $37^{\circ} \mathrm{C}$. Incubations were performed in the dark in order to avoid the photocatalytic effect of $\mathrm{TiO}_{2}$. Concentrations ranging from 100 to $0.024 \mu \mathrm{g} \mathrm{ml}^{-1}$ for $\mathrm{TiO}_{2^{-}}, \mathrm{TiO}_{2^{-}} \mathrm{Ag} \mathrm{g}_{-}$and $0.5-$ $0.001 \mu \mathrm{g} \mathrm{ml}^{-1}$ for Ag NPs with fourfold dilutions were tested. Before infection, the cells were washed twice with phosphate-buffered saline (PBS) and the cells were incubated with the treated and untreated C. trachomatis (multiplicity of infection (MOI) 8) for $1 \mathrm{~h}$, at $37^{\circ} \mathrm{C}$ with a $5 \%$ $\mathrm{CO}_{2}$ atmosphere. After infection, the cells were washed twice with $200 \mu$ l per well of PBS and the culture medium was supplemented with $1 \mu \mathrm{g} \mathrm{ml}^{-1}$ cycloheximide. The plates were incubated at $37^{\circ} \mathrm{C}, 5 \% \mathrm{CO}_{2}$ for $48 \mathrm{~h}$.
Culture of Vero cells and measurement of the impact of NPs on HSV-2 growth

Vero cells (ATCC) were transferred to the wells of a 96well plate at a density of $6 \times 10^{4}$ cells per well in culture medium (see above). Preincubation was performed as described for C. trachomatis. Before infection, the Vero cells were washed twice with PBS and the cells were incubated with the treated and untreated HSV-2 (MOI 0 1 ) for $1 \mathrm{~h}$ at $37^{\circ} \mathrm{C}, 5 \% \mathrm{CO}_{2}$. After the infection, the cells were washed twice with PBS and the plates were incubated for $12 \mathrm{~h}$ at $37^{\circ} \mathrm{C}, 5 \% \mathrm{CO}_{2}$.

\section{Chlamydia trachomatis and HSV-2 growth monitoring} by direct quantitative PCR (qPCR)

After the incubation ( $12 \mathrm{~h}$ for HSV-2, $48 \mathrm{~h}$ for C. trachomatis), the infected host cells were subjected to two freeze-thaw cycles. The mixed cell lysates were used as templates directly in the C. trachomatis and HSV-2-specific qPCRs, as described previously (Eszik et al. 2016; Virók et al. 2017). For each sample, the cycle threshold (Ct) number corresponding to the cycle where the amplification curve crossed the base line was determined. Student's $t$-test was used to evaluate the statistical differences between the $\mathrm{Ct}$ values of the samples (three biological replicates for each condition) as described previously (Yuan et al. 2006).

\section{$\mathrm{TiO}_{2}$ NP treatment of HeLa cells and monitoring of $C$. trachomatis growth on a chamber slide system}

Chamber slides with 16 wells were used to culture HeLa cells for infection with the C. trachomatis as described previously (Bogdanov et al. 2014). Briefly, C. trachomatis (MOI 8) was preincubated with $\mathrm{TiO}_{2} \mathrm{NPs}$ for $1 \mathrm{~h}$ at $37^{\circ} \mathrm{C}$ with a concentration range from 100 to $3 \cdot 12 \mu \mathrm{g} \mathrm{ml}^{-1}$ with twofold dilutions. Incubations were performed in the dark in order to avoid the photocatalytic effect of $\mathrm{TiO}_{2}$. As controls, two wells of HeLa cells infected with untreated C. trachomatis and two wells with uninfected but treated $\left(100 \mu \mathrm{g} \mathrm{ml}^{-1} \mathrm{TiO}_{2}, 1 \mathrm{~h}, 37^{\circ} \mathrm{C}\right)$ HeLa cells were included. The cells were infected/incubated with C. trachomatis or NPs for $1 \mathrm{~h}$, after the culture medium was supplemented with $1 \mu \mathrm{g} \mathrm{ml}^{-1}$ cycloheximide. The cells were incubated at $37^{\circ} \mathrm{C}, 5 \% \mathrm{CO}_{2}$ for $48 \mathrm{~h}$. Chlamydia trachomatis inclusions were identified by anti-chlamydia LPS antibody (AbD Serotec, Oxford, UK) labelled with Alexa-647. The slide was scanned by an Axon GenePix Personal 4100A DNA-chip scanner using the GenePix Pro (ver. 6.1) software (Molecular Devices, Sunnyvale, CA) with the Cy5 channel and a $5-\mu \mathrm{m}$ resolution. Image processing and automatic counting of chlamydial inclusions were performed by the 
ChlamyCount software, as described previously (Bogdanov et al. 2014).

Transmission electron microscopy measurements of early interaction of $\mathrm{TiO}_{2}$ NPs with HeLa and Vero cells

Pellets of HeLa 229 and Vero cells incubated with $100 \mu \mathrm{g} \mathrm{ml}^{-1}$ of $\mathrm{TiO}_{2}\left(1 \mathrm{~h}, 37^{\circ} \mathrm{C}, 5 \% \mathrm{CO}_{2}\right)$ were fixed in $600 \mu \mathrm{l}$ glutaraldehyde. Cell pellets were embedded in Embed 812 (EMS, PA, USA) stained with uranyl acetate and lead citrate, and observed with a JEM-1400 plus electron microscope (JEOL, Peabody, MA).

\section{Results}

Morphological and surface charge properties of the $\mathrm{TiO}_{2^{-}}$, Ag- and $\mathrm{TiO}_{2}-\mathrm{Ag} \mathrm{NPs}$

According to the TEM images, the average particle size of the initial $\mathrm{TiO}_{2}$ NPs was $18.4 \pm 5.65 \mathrm{~nm}$ (Fig. 1a,d). The nominal content of anatase and rutile phases in the commercially available Aeroxide $\mathrm{P} 25 \quad \mathrm{TiO}_{2}$ powder was $80: 20$. The citrate stabilized Ag NPs obtained were nearly globular in shape (Fig. 1b), and their average particle size was $8.2 \pm 3.34 \mathrm{~nm}$ (Fig. 1e). In the case of $\mathrm{TiO}_{2}-\mathrm{Ag} \mathrm{NPs}$, the globular-shaped Ag NPs accumulated on the surface on the $\mathrm{TiO}_{2}$ NPs were clearly seen (Fig. 1c), the average particle size was $21.4 \pm 6.78 \mathrm{~nm}$ (Fig. 1f). Our data show that the sizes of the NPs tested fell into the nanometer range with a high specific surface area.

The surface charge of the NPs tested was calculated from the streaming potential data in each case. Figure 2 shows plots of the charge titration curves, that is, the measured streaming potential of $10 \mathrm{ml} 100 \mu \mathrm{g} \mathrm{ml}^{-1} \mathrm{NP}$ suspensions titrated with $0.01 \%$ HDPCl surfactant solution at $\mathrm{pH}=7.4$ in SPG media. The streaming potential values induced in the aqueous suspensions were negative at this $\mathrm{pH}$. It is well known from the literature that the $\mathrm{TiO}_{2}$ has a $\mathrm{pH}$-dependent surface charge with a point of zero charge value of $6 \cdot 2$ (Preočanin and Kallay 2006). Above this $\mathrm{pH}$ value, the surface of $\mathrm{TiO}_{2}$ is negatively charged. Accordingly, the initial $-250 \mathrm{mV}$ surface charge of the $\mathrm{TiO}_{2}-\mathrm{Ag}$ was continuously increased during the titration process due to the concomitant loss of surface charge. Considering the added amount of the charge compensating surfactant molecules $\left(\mathrm{n}_{\mathrm{HDPCl}}=3.55 \times 10^{-5} \mathrm{mmol}\right)$ and the mass of (a)

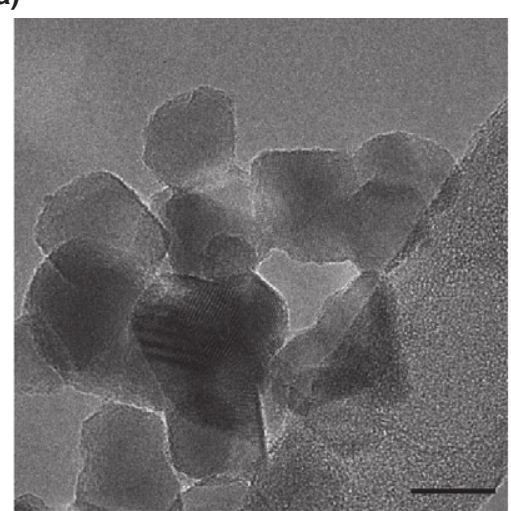

(d)

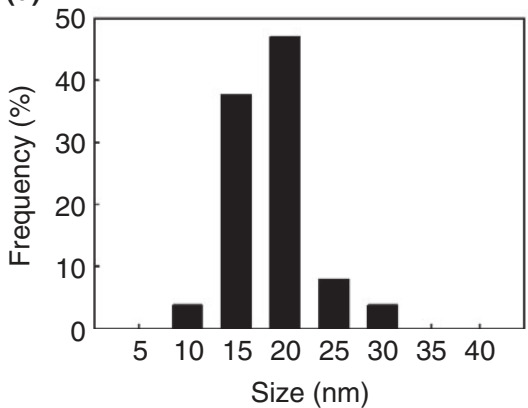

(b)

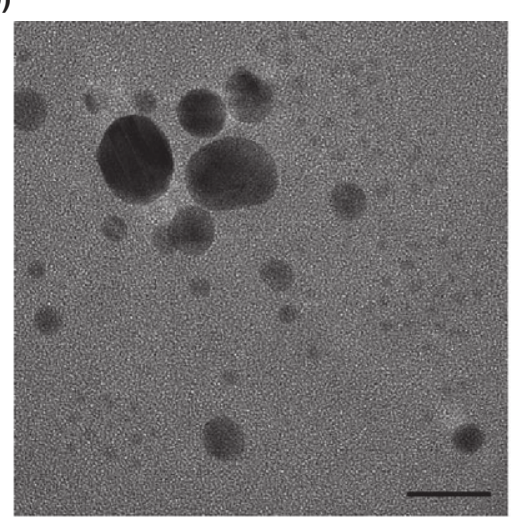

(e)

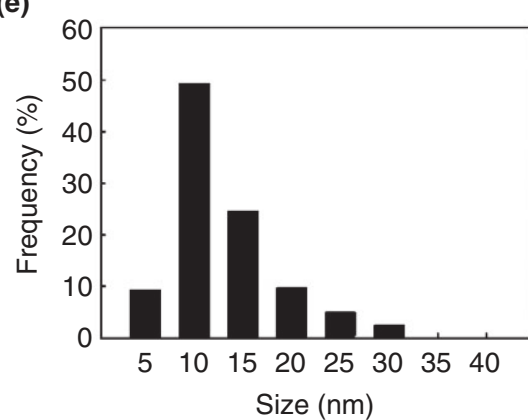

(c)

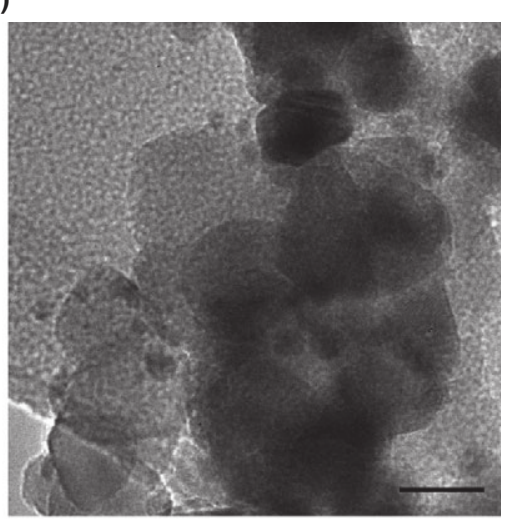

(f)

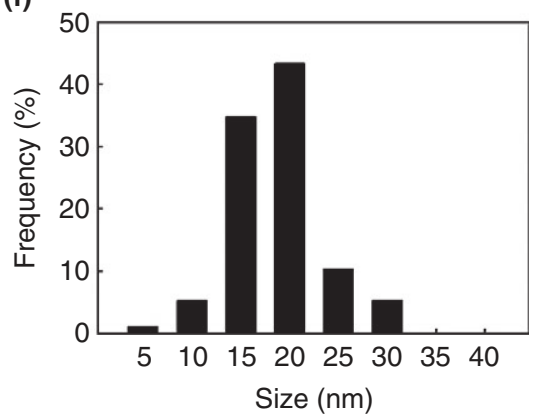

Figure 1 Transmission electron microscopic (TEM) images and size distribution measurements of the nanoparticles (NPs). TEM images of the initial Degussa P25 $\mathrm{TiO}_{2}$ NPs (a), Ag NPs (b) and TiO 2 -Ag NPs (c). Bar: 20 nm. Particle size distributions of Degussa P25 TiO 2 NPs (d), Ag NPs (e) and $\mathrm{TiO}_{2}$-Ag NPs (f). 
Figure 2 Charge titration curves of $10 \mathrm{ml}$ $100 \mu \mathrm{g} \mathrm{ml}^{-1}$ aqueous $\mathrm{TiO}_{2^{-}}, \mathrm{Ag}$ and $\mathrm{TiO}_{2}-\mathrm{Ag}$ NPs suspension with $0.01 \% \mathrm{HDPCl}$ surfactant solution. All the tested nanoparticles $\left(\mathrm{TiO}_{2}\right.$ $\left.(\bullet), \mathrm{Ag}(\mathbf{\nabla}), \mathrm{TiO}_{2}-\mathrm{Ag}(\mathrm{O})\right)$ showed a negative surface charge at $\mathrm{pH}=7.4$, and it was compensated with $\mathrm{HDPCl}$ as opposite charged surfactants with concomitant streaming potential measurements. The calculated surface NP charge values (in meq/ $100 \mathrm{~g}$ unit) can be found in the text.

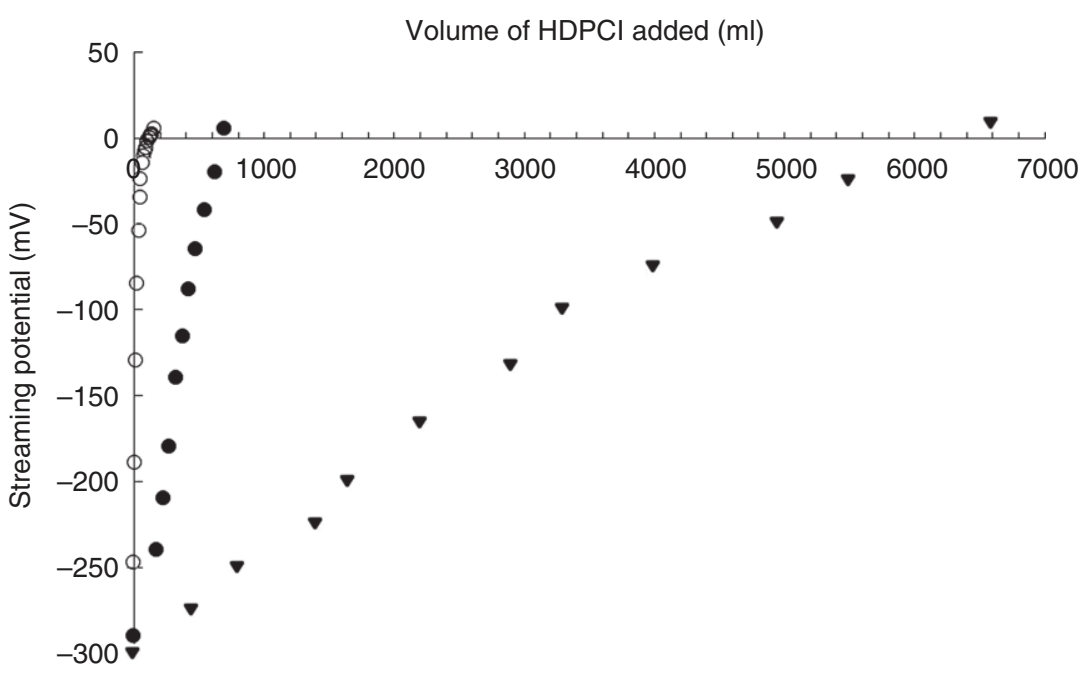

the measured $\mathrm{TiO}_{2}-\mathrm{Ag}\left(\mathrm{m}_{\mathrm{TiO} 2-\mathrm{Ag}}=1 \mathrm{mg}\right)$, the specific surface charge of $\mathrm{TiO}_{2}-\mathrm{Ag}$ NPs was -3.54 meq per $100 \mathrm{~g}$ at $\mathrm{pH}=7 \cdot 4$ (specific charge $=\mathrm{c}_{\mathrm{HDPCl}} \cdot \mathrm{V}_{\mathrm{HDPCl}} / \mathrm{m}_{\mathrm{TiO} 2}$ ). Similar to $\mathrm{TiO}_{2}-\mathrm{Ag} \mathrm{NPs}$, the initial $\mathrm{P} 25 \mathrm{TiO}_{2^{-}}$and $\mathrm{Ag}$ NPs were also titrated and $-19 \cdot 3$ and -184.35 meq per $100 \mathrm{~g}$ values were obtained, respectively. The results clearly showed that the Ag NPs had the highest surface charge value, while the surface charge of $\mathrm{TiO}_{2}-\mathrm{Ag} \mathrm{NPs}$ and $\mathrm{TiO}_{2} \mathrm{NPs}$ were negligible. The measurements also showed that the initial surface charge of the $\mathrm{TiO}_{2}$ NPs $(-19.3$ meq per $100 \mathrm{~g})$ were partially compensated by the Ag NPs with high surface charge $(-184.35$ meq per $100 \mathrm{~g})$. This is due to the surface accumulation of Ag NPs on the surface of $\mathrm{TiO}_{2} \mathrm{NPs}$ in the case of $\mathrm{TiO}_{2}-\mathrm{Ag}$ NPs. This observation is in good agreement with the previously presented TEM images.
Cytotoxicity of the $\mathrm{TiO}_{2^{-}}, \mathrm{Ag}$ - and $\mathrm{TiO}_{2}-\mathrm{Ag} \mathrm{NPs}$

MTT assay was used to assess the cytotoxicity of the NPs applied (Fig. 3a,b). HeLa cells were incubated for $48 \mathrm{~h}$ with a $1: 2$ dilution series of the NPs or were left untreated as controls. We found that $\mathrm{TiO}_{2}$ and $\mathrm{TiO}_{2}-\mathrm{Ag}$ NPs did not produce significant toxicity in the applied concentration range. Maximum cytotoxicity was observed at concentrations of $8-2 \mu \mathrm{g} \mathrm{ml}^{-1}$ for Ag NPs, the viability reached its maximum at $0.5 \mu \mathrm{g} \mathrm{m}^{-1}$. We considered $0.5 \mu \mathrm{g} \mathrm{ml}^{-1}$ as the maximum nontoxic concentration for Ag NPs. The maximum nontoxic concentration of $\mathrm{TiO}_{2}-$ and $\mathrm{TiO}_{2}$-Ag NPs was $100 \mu \mathrm{g} \mathrm{ml}^{-1}$. Vero cells showed similar toxicity profiles. $\mathrm{TiO}_{2}-$ and $\mathrm{TiO}_{2}-\mathrm{Ag}$ NPs were not toxic at the concentrations applied; $0.5 \mu \mathrm{g} \mathrm{ml}^{-1} \mathrm{Ag}$ (a)

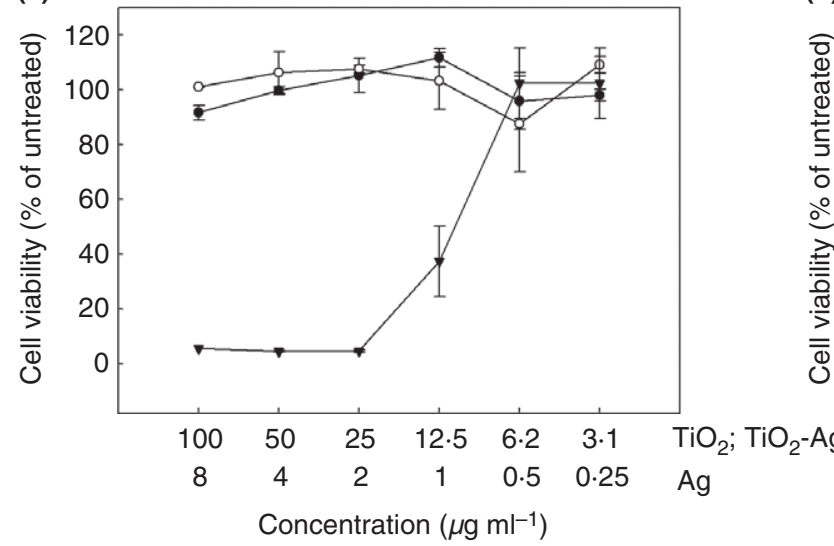

(b)

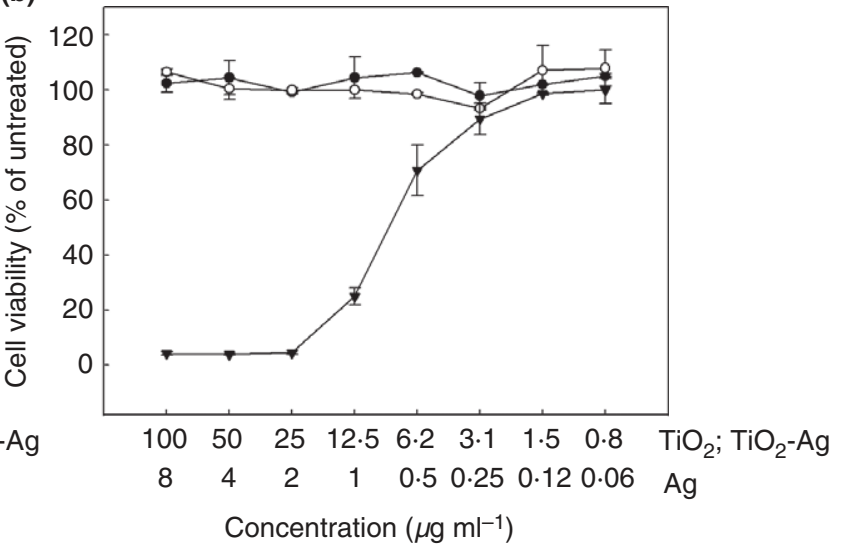

Figure 3 MTT cell viability assay of the NP-treated HeLa and Vero cells. HeLa (a) and Vero (b) cells were treated with a $1: 2$ dilution series of $\mathrm{TiO}_{2}-(\bullet), \mathrm{Ag}-(\boldsymbol{\nabla})$ and $\mathrm{TiO}_{2}-\mathrm{Ag}(\mathrm{O}) \mathrm{NPs}$ for $48 \mathrm{~h}$. MTT assay was performed as described in Materials and Methods. Three parallel measurements were performed for each NP concentration. Data are means \pm standard deviation $(n=3)$. 
NPs treatment resulted a $\sim 70 \%$ viability, and $0.125 \mu \mathrm{g} \mathrm{ml}^{-1}$ was the maximum nontoxic concentration for Ag NPs. To be able to compare the two cell lines, the subsequent growth inhibitory experiments were started with $100 \mu \mathrm{g} \mathrm{ml}^{-1} \quad \mathrm{TiO}_{2^{-}}$and $\mathrm{TiO}_{2}-\mathrm{Ag} \quad \mathrm{NPs}$ and $0.5 \mu \mathrm{g} \mathrm{ml}^{-1}$ Ag NPs.

Direct qPCR measurement of the impact of the $\mathrm{TiO}_{2^{-}}$, Ag- and $\mathrm{TiO}_{2}-\mathrm{Ag}$ NPs on C. trachomatis and HSV-2 growth

We used the recently published direct qPCR methods (Eszik et al. 2016; Virók et al. 2017) to determine the antimicrobial activity of the NPs on C. trachomatis (Fig. 4a) and HSV-2 (Fig. 4b). HeLa or Vero cells were infected with C. trachomatis (MOI 8) or HSV-2 (MOI $0 \cdot 1)$ after preincubation $\left(1 \mathrm{~h}, 37^{\circ} \mathrm{C}\right)$ with serial $1: 4$ dilutions of the NPs, starting with the concentrations of $100 \mu \mathrm{g} \mathrm{ml}^{-1}$ for $\mathrm{TiO}_{2}{ }^{-}$and $\mathrm{TiO}_{2}-\mathrm{Ag}$ NPs, and $0.5 \mu \mathrm{g} \mathrm{ml}^{-1}$ for Ag NPs. It should be noted that the Ag content of the $\mathrm{TiO}_{2}-\mathrm{Ag}$ NPs was the same as that of the $\mathrm{Ag}$ NPs in all of the concentrations applied. Also, it should be mentioned that in order to mimic the in vivo circumstances, we did not use centrifugation for the chlamydial and HSV-2 infections. qPCR measurement of the control, NP-free C. trachomatis growth resulted in a $\mathrm{Ct}$ value of $26 \cdot 81 \pm 0 \cdot 58$. Interestingly, the $\mathrm{TiO}_{2} \mathrm{NPs}$ increased the growth of $C$. trachomatis relative to the control. The growth stimulation was concentrationdependent, with a Ct value of $24.85 \pm 0.64$ at the maximum $\mathrm{TiO}_{2} \mathrm{NP}$ concentration. The 1.96 qPCR cycles $(\Delta \mathrm{Ct}=26 \cdot 81-24 \cdot 85) \quad$ DNA concentration difference between the $\mathrm{TiO}_{2}$ NP-treated and the control C. trachomatis means $\sim 3.89$-fold $\left(\sim 2^{1.96}\right)$ growth increase. Ag NPs had a strong inhibitory activity against C. trachomatis between the $0 \cdot 5-0.031 \mu \mathrm{g} \mathrm{ml}^{-1}$ concentrations. However, $\mathrm{TiO}_{2}-\mathrm{Ag} \mathrm{NPs}$ showed reduced antimicrobial activity compared with the Ag NPs against $C$. trachomatis, despite that the Ag content of the $\mathrm{TiO}_{2}$-Ag NPs was the same as the Ag NPs'. The difference in antichlamydial activity was the most prevalent at the 25 and $6 \cdot 25 \mu \mathrm{g} \mathrm{ml}^{-1} \mathrm{TiO}_{2}-\mathrm{Ag}$ NP concentrations, where the growth difference between the $\mathrm{Ag} \mathrm{NP}$ and $\mathrm{TiO}_{2}-\mathrm{Ag}$ NP-treated chlamydiae was 15.59- and 27.92-fold, respectively (3.96 and 4.8 qPCR cycles difference, respectively).

HSV-2 replication was not influenced by the addition of $\mathrm{TiO}_{2^{-}}$and $\mathrm{TiO}_{2}-\mathrm{Ag} \mathrm{NPs}$, and only slightly inhibited by the highest $0.5 \mu \mathrm{g} \mathrm{ml}^{-1} \mathrm{Ag} \mathrm{NP}$ concentration. This limited inhibition could be due to the impact of Ag NPs on the viability of the host cells.

\section{Measurement of the time dependence of the $\mathrm{TiO}_{2}$ growth enhancing effect on C. trachomatis}

To identify the exact time window when the $\mathrm{TiO}_{2} \mathrm{NPs}$ alter $C$. trachomatis growth, we performed an experiment where (i) the $\mathrm{TiO}_{2} \mathrm{NPs}$ were preincubated with the $C$. trachomatis elementary bodies 1 hour before infection and coincubated during the infection for an additional hour, (ii) the $\mathrm{TiO}_{2} \mathrm{NPs}$ were coincubated with the C. trachomatis elementary bodies during the 1-h-long infection, (iii) the $\mathrm{TiO}_{2}$ NPs were added to the C. trachomatisinfected HeLa cells at various timepoints $(0-32 \mathrm{~h})$ post infection (Fig. 5a). In order to compare the effects of
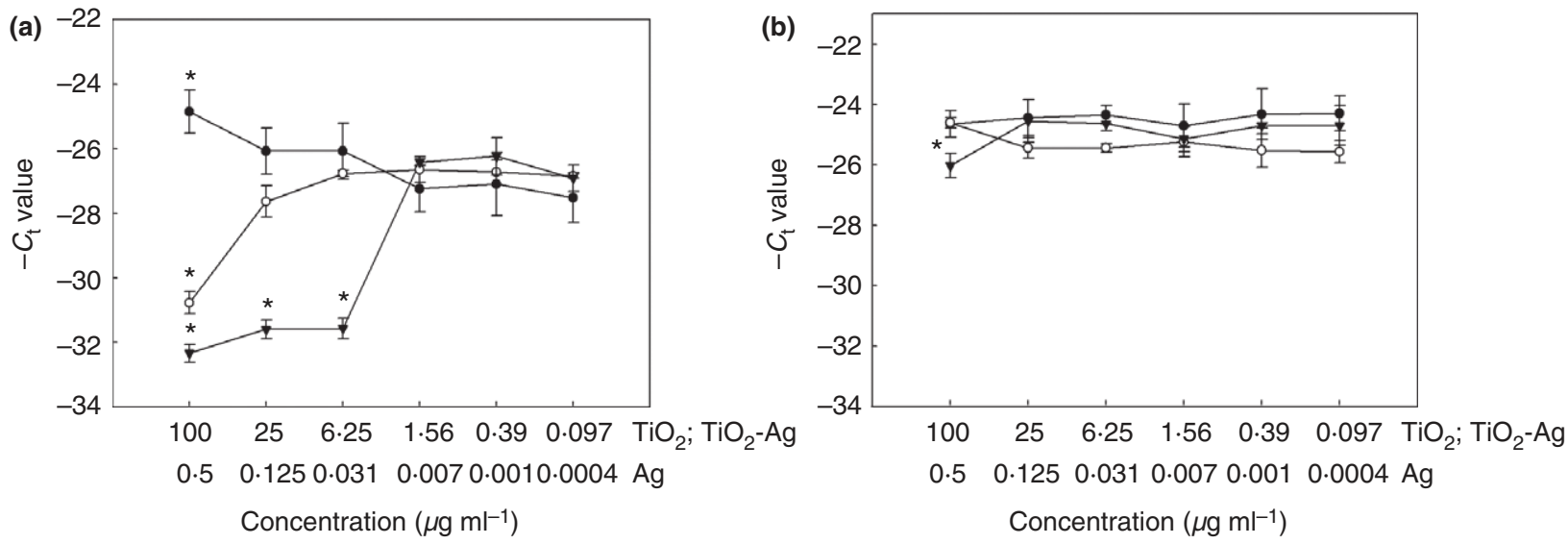

Figure 4 Measurement of the antimicrobial activity of the $\mathrm{TiO}_{2^{-}}, \mathrm{Ag}-$ and $\mathrm{TiO}_{2}-\mathrm{Ag} \mathrm{NPs}$ by direct qPCR. HeLa cells were infected with Chlamydia trachomatis (MOI 8) preincubated with a $1: 4$ dilution series of $\mathrm{TiO}_{2^{-}}(\bullet)$, Ag- $(\boldsymbol{\nabla})$ and $\mathrm{TiO}_{2}-\mathrm{Ag}(\mathrm{O}) \mathrm{NPs}$ for $1 \mathrm{~h} 37^{\circ} \mathrm{C}(\mathrm{a})$. Vero cells were infected with HSV-2 (MOI 0.1) preincubated with a 1:4 dilution series of $\mathrm{TiO}_{2^{-}}$, Ag- and $\mathrm{TiO}_{2}-\mathrm{Ag}$ NPs for $1 \mathrm{~h} 37^{\circ} \mathrm{C}$ (b). Each infection at a particular NP concentration was performed in three parallel wells. At $48 \mathrm{~h}$ post infection (C. trachomatis) and $12 \mathrm{~h}$ post infection (HSV-2), the cells were lysed and the DNA concentrations of the pathogens were measured by pathogen-specific direct qPCRs. Data are the average $-C t$ values \pm standard deviation $(n=3)$. Student's $t$-test was used to compare the Ct values between the treated and untreated infected cells ( $*$ : $<0.05$ ). 
(a)

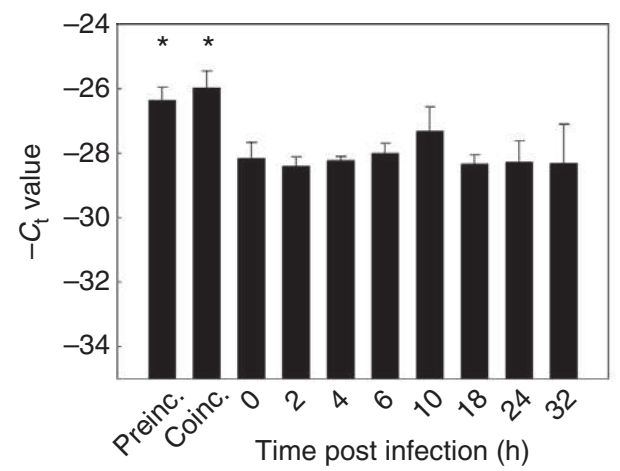

(b)

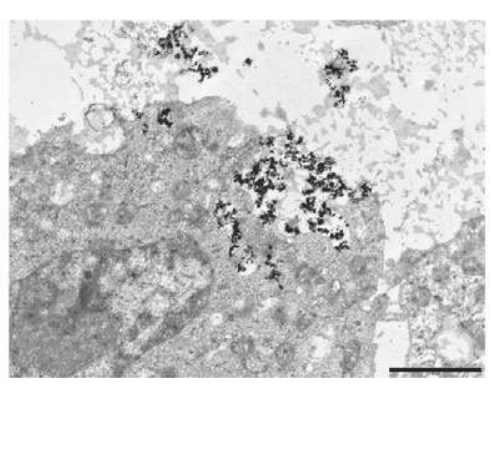

(c)

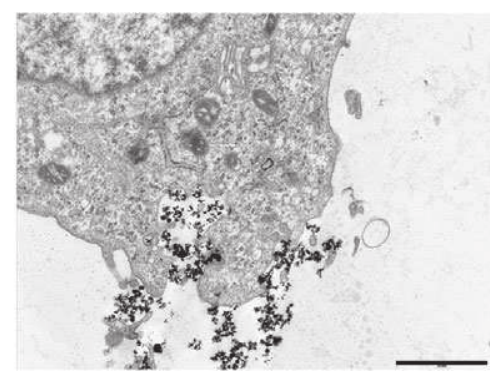

Figure 5 Measurement of the kinetics of the $\mathrm{TiO}_{2} \mathrm{NP}$-mediated Chlamydia trachomatis growth enhancement and visualization of the $\mathrm{TiO}_{2} \mathrm{NP}$ uptake. $\mathrm{TiO}_{2} \mathrm{NPs}\left(100 \mu \mathrm{g} \mathrm{ml}^{-1}\right)$ were applied at different timepoints post infection. At $48 \mathrm{~h}$ post infection, the infected HeLa cells were lysed and the chlamydial DNA concentration was measured by qPCR $(n=3)$. preinc: $\mathrm{TiO}_{2} \mathrm{NPs}$ were preincubated with the $\mathrm{C}$. trachomatis elementary bodies $\left(1 \mathrm{~h}, 37^{\circ} \mathrm{C}\right)$ and $\mathrm{TiO}_{2}$ NPs were also present during the infection process $\left(1 \mathrm{~h}, 37^{\circ} \mathrm{C}\right)$; coinc.: TiO $\mathrm{NPs}$ were present only during the infection process $\left(1 \mathrm{~h}, 37^{\circ} \mathrm{C}\right)$. Data are the average $-\mathrm{Ct}$ values \pm standard deviation $(n=3)$. TEM images of the uptake $\left(1 \mathrm{~h}\right.$ post treatment, $\left.37^{\circ} \mathrm{C}\right)$ of $\mathrm{TiO}_{2}$ NPs by HeLa (b) and Vero cells (c). Bar is $10 \mu \mathrm{m}$. Student's $t$-test were used to compare the $\mathrm{Ct}$ values between the TiO ${ }_{2}-\mathrm{NP}$-treated and untreated infected cells (*: $P<0.05)$.

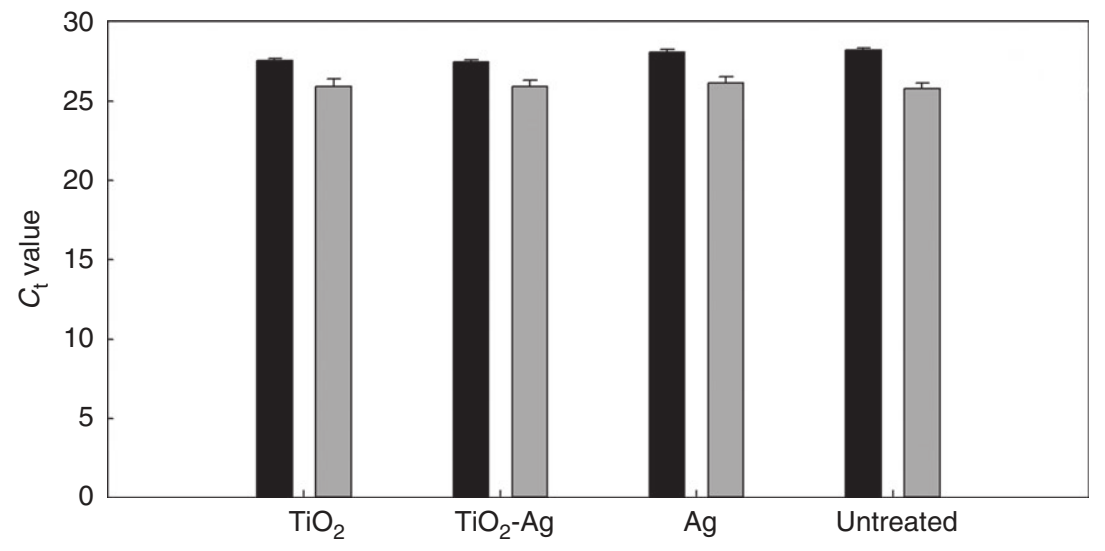

Figure 6 Estimation of the direct impact of $\mathrm{TiO}_{2^{-}}, \mathrm{Ag}$ - and $\mathrm{TiO}_{2}-\mathrm{Ag}$ NPs on the qPCR. Cell lysates of HeLa cells (filled bars) infected with untreated Chlamydia trachomatis ( $\mathrm{MOI} 8,48 \mathrm{~h}$ post infection) mixed with cell lysates from uninfected HeLa cells treated with $200 \mu^{-1} \mathrm{ml}^{-1} \mathrm{TiO}_{2}$ NPs, $200 \mu \mathrm{g} \mathrm{ml}^{-1} \mathrm{TiO}_{2}$-Ag NPs and $1 \mu \mathrm{g} \mathrm{ml}^{-1} \mathrm{Ag} \mathrm{NPs}$, respectively $(n=3)$. Ct values were compared with the untreated C. trachomatis infected cells $(n=3)$. Cell lysates of Vero cells (open bars) infected with untreated HSV-2 (MOI 0.1, 24 h post infection) mixed with cell lysates from uninfected Vero cells treated with $200 \mu \mathrm{g} \mathrm{ml}^{-1} \mathrm{TiO}_{2} \mathrm{NPs}, 200 \mu \mathrm{g} \mathrm{ml}^{-1} \mathrm{TiO}_{2}$-Ag NPs and $1 \mu \mathrm{g} \mathrm{ml} \mathrm{I}^{-1} \mathrm{Ag} \mathrm{NPs}$, respectively ( $n=3$ ). Ct values were compared with the untreated HSV-2-infected cells $(n=3)$. Data are the average Ct values \pm standard deviation $(n=3)$. Black bars.

$\mathrm{TiO}_{2}$ NPs at various timepoints, the $\mathrm{TiO}_{2}$ NPs were applied for the same duration $(1 \mathrm{~h})$ at each timepoint and after they were washed away. No centrifugation was used for the infection. Data showed that the growth enhancing effect of $\mathrm{TiO}_{2}$ NPs was detected at the coincubation + infection treatment ( $\sim 2$ qPCR cycles, fourfold growth increase), and when the $\mathrm{TiO}_{2}$ was applied during the 1-hour infection ( 2 qPCR cycles, fourfold growth increase). It is worth to note, that a second, nonsignificant growth increase was detected at $10 \mathrm{~h}$ post infection. The TEM images showed that both HeLa and Vero cells incorporated the $\mathrm{TiO}_{2}$ NPs (Fig. 5b,c); therefore, the lack of HSV-2 growth increasing effect in Vero cells is not due to the cells' inability of $\mathrm{TiO}_{2} \mathrm{NP}$ uptake.

Estimation of the direct impact of the $\mathrm{TiO}_{2^{-}}, \mathrm{Ag}$ - and $\mathrm{TiO}_{2}-\mathrm{Ag} \mathrm{NPs}$ on the qPCR

Since the growth-related chlamydial DNA concentrations were measured by a direct qPCR method, we wanted to test the potential impact of the NPs on the DNA polymerase of the qPCR (Fig. 6). A qPCR enzyme inhibitory effect would appear as a false antichlamydial activity, while a stimulatory effect would appear as a false 
chlamydial growth enhancing effect. Cell lysates of HeLa cells infected with untreated $C$. trachomatis were mixed with cell lysates from uninfected cells treated with twice the maximum concentration of NPs used in the qPCR experiments, so that the final concentration of the NPs in this mixture would be the maximal concentration applied in the growth inhibition experiments. As controls, uninfected and untreated cell lysates were also mixed with $C$. trachomatis-infected cell lysates. If there was no direct impact of NPs on the qPCR, then the Ct levels of the mixture of the infected and uninfected but NP containing cell lysates would have been similar to the above-mentioned controls. The $\mathrm{Ct}$ levels of the C. trachomatis $+\mathrm{TiO}_{2} \mathrm{NP}, C$. trachomatis $+\mathrm{TiO}_{2}-\mathrm{Ag} \mathrm{NP}$ and $C$. trachomatis + Ag NP mixtures were only 0.64, 0.73 and $0 \cdot 11$ cycles lower, respectively, than the control's. Similar experiments were performed to test the impact of NPs on the HSV-2 qPCR. The Ct levels of the HSV-2 $+\mathrm{TiO}_{2}$ $\mathrm{NP}, \mathrm{HSV}-2+\mathrm{TiO}_{2}-\mathrm{Ag} \mathrm{NP}$ and HSV-2 $+\mathrm{Ag} \mathrm{NP}$ mixtures were only $0 \cdot 14,0 \cdot 143$ and $0 \cdot 34$ cycles lower, respectively, than the control's. These results support the presumption that the observed increase or decrease of $C$. trachomatis and HSV-2 growth could not be due to the stimulation or inhibition of the qPCR itself.

Quantitative immunofluorescent measurement of the impact of $\mathrm{TiO}_{2} \mathrm{NPs}$ on C. trachomatis growth

An independent immunofluorescent growth measurement method was used to validate the qPCR results (Fig. 7). HeLa cells cultured on a 16-well chamber slide were infected with $C$. trachomatis (MOI 8) after preincubation at various concentrations of $\mathrm{TiO}_{2}$ NPs. No centrifugation was used for the infection. Infected but untreated and uninfected $+\mathrm{TiO}_{2}$ NP-treated cells $\left(100 \mu \mathrm{g} \mathrm{ml}^{-1}\right)$ were also included as controls. Cells were fixed at $48 \mathrm{~h}$ post infection, and the chlamydial inclusions were labelled with an Alexa-647-labelled anti-chlamydia LPS antibody. As described previously (Bogdanov et al. 2014), the slide was scanned with a DNA-chip scanner, and the ChlamyCount software was used to enumerate the chlamydial inclusions. ChlamyCount inclusion number counts supported the $\mathrm{qPCR}$ results. $\mathrm{TiO}_{2} \mathrm{NP}$ pretreatment of the chlamydial elementary bodies induced an increase in chlamydial inclusion numbers, with a $400-500 \%$ increase at the 100 and $50 \mu \mathrm{g} \mathrm{ml}^{-1} \mathrm{TiO}_{2}$ NPs concentrations, and a gradual, concentration-dependent decrease in growth enhancement in the 25-3.12 $\mu \mathrm{g} \mathrm{ml}^{-1} \mathrm{TiO}_{2}$ NPs concentration range. Uninfected but $\mathrm{TiO}_{2}$ NP-treated wells displayed only marginal positivity, indicating that the observed increase of chlamydial immunofluorescence was not due to the aspecific binding of the anti-chlamydial LPS antibody to $\mathrm{TiO}_{2}$ NPs.

\section{Discussion}

As the uptake of $\mathrm{TiO}_{2}$ NPs is significant and the prevalence of C. trachomatis and HSV-2 is high, it is important to study their interactions. Therefore, we performed an in vitro study where we evaluated the impact of nonactivated $\mathrm{TiO}_{2}$ NPs on the growth of $C$. trachomatis and HSV-2. Since the activated $\mathrm{TiO}_{2} \mathrm{NPs}$ have well-described

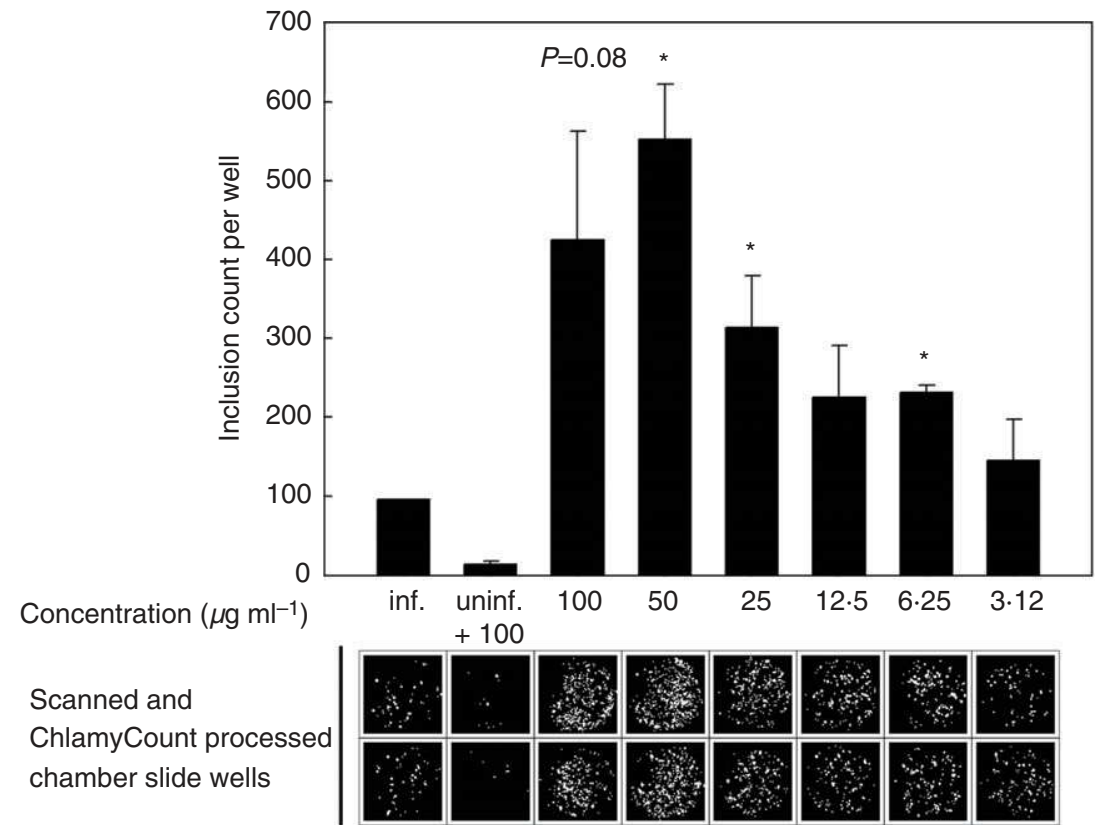

Figure 7 Measurement of the impact of $\mathrm{TiO}_{2}$ NPs on Chlamydia trachomatis growth. HeLa cells were infected with C. trachomatis (MOI 8 ) in the presence of a concentration range of $\mathrm{TiO}_{2} \mathrm{NPs}$. Untreated C. trachomatisinfected wells and uninfected $\mathrm{TiO}_{2}$-NP-treated wells were included as controls. Each infection was performed using parallel wells. The chlamydial inclusions were enumerated by the ChlamyCount software $48 \mathrm{~h}$ post infection. The ChlamyCount processed well images and the inclusion numbers counted are shown. Data are means \pm standard deviation ( $n=2)$. Student's $t$-test were used to compare the inclusion counts between $\mathrm{TiO}_{2}$-NP-treated and untreated infected cells $(*: P<0.05)$ 
antimicrobial activity, we hypothesized that the nonactivated $\mathrm{TiO}_{2}$ NPs would not have any effect on the growth of these two intracellular pathogens. Indeed, $\mathrm{TiO}_{2^{-}}$and $\mathrm{TiO}_{2}$-Ag NPs had no effect on HSV-2 growth in the tested concentration range, and Ag NPs only displayed a minimal inhibition (about twofold) at the highest concentration. It is worth to note that the addition of $\mathrm{TiO}_{2}$ to Ag NPs eliminated completely this minimal HSV-2 inhibitory activity. However, qPCR growth measurements showed that the $\mathrm{TiO}_{2}$ NPs significantly promoted the chlamydial growth at the $100 \mu \mathrm{g} \mathrm{ml}^{-1}$ concentration. Albeit not reached the significance threshold, the growthpromoting effect could also be detected at the 50 and $25 \mu \mathrm{g} \mathrm{ml}^{-1}$ concentrations. Since the growth-promoting effect of $\mathrm{TiO}_{2}$ NPs was unexpected, and chlamydial DNA synthesis can be observed in the absence of active growth (e.g. in persistence), we applied an independent, immunofluorescence-based method to validate the data. We applied the ChlamyCount system to quantitate chlamydial inclusions. ChlamyCount measurements supported the qPCR data with a prominent growth increasing effect at the 100 and $50 \mu \mathrm{g} \mathrm{ml}^{-1} \quad \mathrm{TiO}_{2} \quad \mathrm{NP}$ concentration range. The observed $\mathrm{TiO}_{2}$ growth increase of $C$. trachomatis was unexpected, but not without precedent in the literature. A recent study by $\mathrm{Xu}$ et al. (2016) showed that nonactivated $\mathrm{TiO}_{2}$ NPs increased the attachment/internalization of Staphylococcus aureus to HeLa cells. HeLa cells treated with $100 \mu \mathrm{g} \mathrm{ml}^{-1} \mathrm{TiO}_{2} \mathrm{NPs}$ (the same concentration that increased the growth of C. trachomatis by about $400 \%$ in our study) for $24 \mathrm{~h}$ resulted in a $250-350 \%$ increase of $S$. aureus attachment/internalization.

In contrast to the chlamydial infection, $\mathrm{TiO}_{2} \mathrm{NPs}$ did not alter HSV-2 growth; therefore, the HSV developmental cycle does not benefit from the cellular process(es) that was induced by $\mathrm{TiO}_{2} \mathrm{NPs}$, or the $\mathrm{TiO}_{2} \mathrm{NPs}$ could not induce the growth-promoting cellular effects in Vero cells. Our data support the latter: since $\mathrm{TiO}_{2}$ NPs were not able to increase chlamydial growth in Vero cells (data not shown), the $\mathrm{TiO}_{2}$ NP-related growth-promoting effect had a cell-type dependent component.

Chlamydia has a complex developmental cycle, starting with the attachment of the infectious form, the so-called elementary body to the plasma membrane of the target cells. After attachment, the elementary body enters the cell and differentiates to the noninfectious, but replicating form, the reticulate body. Reticulate bodies grow in a membrane bound vacuole, the so-called inclusion in the cytoplasm of the host cell. The reticulate bodies then redifferentiate to elementary bodies and exit the host cells 48-72 h post infection. Theoretically, this complex developmental cycle can be influenced by the $\mathrm{TiO}_{2} \mathrm{NPs}$ at various stages. Our kinetic experiments revealed that the
$\mathrm{TiO}_{2}$ NPs promoted chlamydial growth when they were added to the elementary bodies before the infection or added during the infection. This result indicates that $\mathrm{TiO}_{2}$ NPs facilitated the attachment/entry of the chlamydial elementary bodies to the host cells. Chlamydia enters into the target cell via multiple mechanisms including phagocytosis, caveolae-mediated endocytosis and clathrinmediated endocytosis. Among these processes, clathrinmediated endocytosis seems to be important for C. trachomatis entry to epithelial cells (Hybiske and Stephens 2007). $\mathrm{TiO}_{2}$ NPs can also enter via clathrin-mediated endocytosis (Gitrowski et al. 2014), and thus, there is a possibility that the $\mathrm{TiO}_{2} \mathrm{NP}$ entry co-stimulates the entry of the chlamydial elementary bodies. However, our TEM images showed $\mathrm{TiO}_{2}$ NP incorporation after $1 \mathrm{~h}$ post incubation in both HeLa and Vero cells, while the chlamydial growth-promoting effect could not be detected in Vero cells (data not shown); therefore, a mechanistic co-uptake is not likely the source of growth promotion. The net charge of the $C$. trachomatis elementary bodies is negative (Söderlund and Kihlström 1982), and the infectivity of the C. trachomatis urogenital serovars (D-K) can be enhanced by polycations such as DEAE-dextran and poly-L lysine and can be inhibited by polyanions such as dextran-sulphate (Kuo et al. 1973). The observed chlamydial growth-promoting effect cannot be explained by the $\mathrm{TiO}_{2} \mathrm{NP}$-mediated bridging of the negatively charged $C$. trachomatis elementary body and the negatively charged host cell plasma membrane, since the net charge of the $\mathrm{TiO}_{2}$ NPs was close to zero. Altogether these data indicate that the $\mathrm{TiO}_{2}$ NPs binding/incorporation itself is not a key factor in chlamydial growth promotion, rather the incorporated $\mathrm{TiO}_{2} \mathrm{NPs}$ may induce a unique early signal transduction or plasma membrane alteration in HeLa cells that are beneficial to chlamydial growth. It is also worth to note that in vivo the $\mathrm{TiO}_{2}$ NPs could have additional effects that can increase chlamydial growth, including the impairment of tryptophan degradation and inhibition of interferongamma production (Becker et al. 2014). These effects are particularly interesting, since tryptophan degradation by the interferon-induced indoleamine 2,3-dioxygenase enzyme is considered to be a major mechanism in the clearance of chlamydial infections in humans (Roshick et al. 2006).

Silver-containing antimicrobials were commonly used before to treat $C$. trachomatis conjunctival infections and were shown to inhibit HSV-2 replication (Shimizu et al. 1976). Interestingly, while the pure $\mathrm{TiO}_{2}$ NPs did not influence HSV growth, the $\mathrm{TiO}_{2}$-Ag NPs showed reduced antimicrobial activity against both $C$. trachomatis and HSV-2 than the Ag NPs. The reduction of antichlamydial activity in certain concentrations was close to 30 -fold. It 
is possible that the antichlamydial effect of Ag NPs - at least partially-is due to their high negative charge. As we showed, the $\mathrm{TiO}_{2}-\mathrm{Ag}$ NPs have a more positive net charge compared with Ag NPs, which may contribute to the lower antichlamydial effect.

Our study is the first, where the impact of nonactivated $\mathrm{TiO}_{2}$ NPs on the growth of these two important intracellular pathogens has been measured. Because of the high prevalence and debilitating sequelae of C. trachomatis infections, the $\mathrm{TiO}_{2} \mathrm{NP}$-induced growth promotion is a significant finding which requires further animal model/epidemiology investigations. An important application of NPs is the drug delivery of antimicrobials. It is generally accepted that the antichlamydial effect of the first-choice antibiotic azithromycin is augmented by its intracellular accumulation (Niki et al. 1994). Theoretically, the uptake and intracellular accumulation of $\mathrm{TiO}_{2}$ NPs make them particularly amenable for use as antimicrobial compound delivery vehicle to combat intracellular pathogens. The fact that addition of $\mathrm{TiO}_{2}$ greatly reduced the antichlamydial activity and reduced the antiviral activity of Ag NPs highlights the need for further testing of $\mathrm{TiO}_{2} \mathrm{NPs}$ in this application.

\section{Funding}

The study was supported by the Hungarian Scientific Research Fund (NKFIH-OTKA) K 116323 and PD 116224, GINOP-2.3.2-15-2016-00013 and EFOP-3.6.1-162016-00008. This article was supported by the János Bolyai Research Scholarship of the Hungarian Academy of Sciences.

\section{Conflict of Interest}

The authors declare that they have no competing interests.

\section{References}

Becker, K., Schroecksnadel, S., Geisler, S., Carriere, M., Gostner, J.M., Schennach, H., Herlin, N. and Fuchs, D. (2014) $\mathrm{TiO}(2)$ nanoparticles and bulk material stimulate human peripheral blood mononuclear cells. Food Chem Toxicol 65, 63-69.

Blaho, J.A., Morton, E.R. and Yedowitz, J.C. (2005) Herpes simplex virus: propagation, quantification, and storage. Current Protocols in Microbiology Chapter 14, Unit 14E.1. doi:10.1002/9780471729259.mc14e01s00.

Bogdanov, A., Endrész, V., Urbán, S., Lantos, I., Deák, J., Burián, K., Önder, K., Ayaydin, F. et al. (2014) Application of DNA chip scanning technology for automatic detection of Chlamydia trachomatis and
Chlamydia pneumoniae inclusions. Antimicrob Agents Chemother 58, 405-413.

Csapó, E., Patakfalvi, R., Hornok, V., Tóth, L.T., Sipos, A., Szalai, A., Csete, M. and Dékány, I. (2012) Effect of pH on stability and plasmonic properties of cysteinefunctionalized silver nanoparticle dispersion. Colloids Surf B Biointerfaces 98, 43-49.

Eszik, I., Lantos, I., Önder, K., Somogyvári, F., Burián, K., Endrész, V. and Virok, D.P. (2016) High dynamic range detection of Chlamydia trachomatis growth by direct quantitative PCR of the infected cells. J Microbiol Methods 120, 15-22.

Faria, H.A.M. and de Queiroz, A.A.A. (2015) A novel drug delivery of 5-fluorouracil device based on $\mathrm{TiO}_{2} / \mathrm{ZnS}$ nanotubes. Mater Sci Eng C Mater Biol Appl 56, 260-268.

Geraets, L., Oomen, A.G., Krystek, P., Jacobsen, N.R., Wallin, H., Laurentie, M., Verharen, H.W., Brandon, E.F.A. et al. (2014) Tissue distribution and elimination after oral and intravenous administration of different titanium dioxide nanoparticles in rats. Part Fibre Toxicol 11, 30.

Gitrowski, C., Al-Jubory, A.R. and Handy, R.D. (2014) Uptake of different crystal structures of $\mathrm{TiO}_{2}$ nanoparticles by Caco-2 intestinal cells. Toxicol Lett 226, 264-276.

Györgyey, Á., Janovák, L., Ádám, A., Kopniczky, J., Tóth, K.L., Deák, Á., Panayotov, I., Cuisinier, F. et al. (2016) Investigation of the in vitro photocatalytic antibacterial activity of nanocrystalline $\mathrm{TiO}_{2}$ and coupled $\mathrm{TiO}_{2} / \mathrm{Ag}$ containing copolymer on the surface of medical grade titanium. J Biomater Appl 31, 55-67.

Hybiske, K. and Stephens, R.S. (2007) Mechanisms of Chlamydia trachomatis entry into nonphagocytic cells. Infect Immun 75, 3925-3934.

Kuo, C.C., Wang, S.P. and Grayston, J.T. (1973) Effect of polycations, polyanions and neuraminidase on the infectivity of trachoma-inclusion conjunctivitis and lymphogranuloma venereum organisms HeLa cells: sialic acid residues as possible receptors for trachoma-inclusion conjunction. Infect Immun 8, 74-79.

Levina, A.S., Repkova, M.N., Mazurkova, N.A., Makarevich, E.V., Ismagilov, Z.R. and Zarytova, V.F. (2015) Knockdown of different influenza A virus subtypes in cell culture by a single antisense oligodeoxyribonucleotide. Int J Antimicrob Agents 46, 125-128.

Looker, K.J., Magaret, A.S., Turner, K.M.E., Vickerman, P., Gottlieb, S.L. and Newman, L.M. (2015) Global estimates of prevalent and incident herpes simplex virus type 2 infections in 2012. PLoS ONE 10, e114989.

Niki, Y., Kimura, M., Miyashita, N. and Soejima, R. (1994) In vitro and in vivo activities of azithromycin, a new azalide antibiotic, against chlamydia. Antimicrob Agents Chemother 38, 2296-2299.

Párducz, L., Eszik, I., Wagner, G., Burián, K., Endrész, V. and Virok, D.P. (2016) Impact of antiseptics on Chlamydia trachomatis growth. Lett Appl Microbiol 63, 260-267. 
Peters, R.J.B., van Bemmel, G., Herrera-Rivera, Z., Helsper, H.P.F.G., Marvin, H.J.P., Weigel, S., Tromp, P.C., Oomen, A.G. et al. (2014) Characterization of titanium dioxide nanoparticles in food products: analytical methods to define nanoparticles. J Agric Food Chem 62, 6285-6293.

Preočanin, T. and Kallay, N. (2006) Point of zero charge and surface charge density of $\mathrm{TiO}_{2}$ in aqueous electrolyte solution as obtained by potentiometric mass titration. Croatia Chemica Acta 79, 95-106.

Roshick, C., Wood, H., Caldwell, H.D. and McClarty, G. (2006) Comparison of gamma interferon-mediated antichlamydial defense mechanisms in human and mouse cells. Infect Immun 74, 225-238.

Sabet, S.F., Simmons, J. and Caldwell, H.D. (1984) Enhancement of Chlamydia trachomatis infectious progeny by cultivation of HeLa 229 cells treated with DEAEdextran and cycloheximide. J Clin Microbiol 20, 217-222.

Shen, S., Wu, L., Liu, J., Xie, M., Shen, H., Qi, X., Yan, Y., Ge, Y. et al. (2015) Core-shell structured Fe3O4@TiO2doxorubicin nanoparticles for targeted chemosonodynamic therapy of cancer. Int J Pharm 486, 380-388.

Shimizu, F., Shimizu, Y. and Kumagai, K. (1976) Specific inactivation of herpes simplex virus by silver nitrate at low concentrations and biological activities of the inactivated virus. Antimicrob Agents Chemother 10, 57-63.

Söderlund, G. and Kihlström, E. (1982) Physicochemical surface properties of elementary bodies from different serotypes of Chlamydia trachomatis and their interaction with mouse fibroblasts. Infect Immun 36, 893-899.

Tsapis, N., Bennett, D., Jackson, B., Weitz, D.A. and Edwards, D.A. (2002) Trojan particles: Large porous carriers of nanoparticles for drug delivery. Proc Natl Acad Sci 99, 12001-12005.

Venkatasubbu, G.D., Ramasamy, S., Gaddam, P.R. and Kumar, J. (2015) Acute and subchronic toxicity analysis of surface modified paclitaxel attached hydroxyapatite and titanium dioxide nanoparticles. Int J Nanomed 10(Suppl. 1), 137148.
Veres, Á., Ménesi, J., Juhász, Á., Berkesi, O., Ábrahám, N., Bohus, G., Oszkó, A., Pótári, G. et al. (2014) Photocatalytic performance of silver-modified $\mathrm{TiO} 2$ embedded in poly(ethyl-acrylate-co-methyl metacrylate) matrix. Colloid Polym Sci 292, 207-217.

Virók, D.P., Eszik, I., Mosolygó, T., Önder, K., Endrész, V. and Burián, K. (2017) A direct quantitative PCR-based measurement of herpes simplex virus susceptibility to antiviral drugs and neutralizing antibodies. J Virol Methods 242, 46-52.

Wang, J., Zhou, G., Chen, C., Yu, H., Wang, T., Ma, Y., Jia, G., Gao, Y. et al. (2007) Acute toxicity and biodistribution of different sized titanium dioxide particles in mice after oral administration. Toxicol Lett 168, 176-185.

Weir, A., Westerhoff, P., Fabricius, L., Hristovski, K. and von Goetz, N. (2012) Titanium dioxide nanoparticles in food and personal care products. Environ Sci Technol 46, 22422250.

WHO (2001) Global prevalence and incidence of selected curable sexually transmitted infections: overview and estimates. Available from: http://www.who.int/reprod uctivehealth/publications/rtis/HIV_AIDS_2001_2/en/ (accessed 14 November 2014).

Xu, Y., Wei, M.-T., Ou-Yang, H.D., Walker, S.G., Wang, H.Z., Gordon, C.R., Guterman, S., Zawacki, E. et al. (2016) Exposure to $\mathrm{TiO}_{2}$ nanoparticles increases Staphylococcus aureus infection of HeLa cells. J Nanobiotechnol 14, 34.

Yuan, J.S., Reed, A., Chen, F. and Stewart, C.N. (2006) Statistical analysis of real-time PCR data. BMC Bioinformatics 7, 85.

Zaqout, M.S.K., Sumizawa, T., Igisu, H., Higashi, T. and Myojo, T. (2011) Binding of human serum proteins to titanium dioxide particles in vitro. J Occup Health 53, 7583.

Zeidler, H. and Hudson, A.P. (2016) Causality of Chlamydiae in arthritis and spondyloarthritis: a plea for increased translational research. Curr Rheumatol Rep 18, 9. 